\author{
UNIVERSIDADE DE SÃO PAULO \\ FACULDADE DE ZOOTECNIA E ENGENHARIA DE ALIMENTOS
}

PABLO LUIS FAZZANARO

Avaliação dos protocolos ZigBee e IEEE 802.11ah através de simulação computacional para aplicação no agronegócio 


\title{
Avaliação dos protocolos ZigBee e IEEE 802.11ah através de simulação computacional para aplicação no agronegócio
}

\author{
"Versão corrigida"
}

Dissertação apresentada à Faculdade de Zootecnia e Engenharia de Alimentos da Universidade de São Paulo, como parte dos requisitos para a obtenção do Título de Mestre em Ciências do programa em Gestão e Inovação na Indústria Animal.

Área de concentração: Gestão e Inovação na Indústria Animal

Orientador: Prof. Dr. Adriano Rogério Bruno Tech 
Ficha catalográfica elaborada pelo

Serviço de Biblioteca e Informação, FZEA/USP, com os dados fornecidos pelo(a) autor(a)

Fazzanaro, Pablo Luis

Avaliação dos protocolos ZigBee e IEEE 802.11ah através de simulação computacional para aplicação no agronegócio / Pablo Luis Fazzanaro ; orientador Prof. Dr. Adriano Rogério Bruno Tech. -Pirassununga, 2016.

$102 \mathrm{f}$.

Dissertação (Mestrado - Programa de Pós-Graduação em Mestrado Profissional em Gestão e Inovação na Industria Animal) -- Faculdade de Zootecnia e Engenharia de Alimentos, Universidade de São Paulo.

1. Agronegócio. 2. Redes de sensores sem fio. 3. Zigbee. 4. IEEE 802.11ah. I. Tech, Prof. Dr. Adriano Rogério Bruno, orient. II. Título. 
PABLO LUIS FAZZANARO

\title{
Avaliação dos protocolos ZigBee e IEEE 802.11ah através de simulação computacional para aplicação no agronegócio
}

\begin{abstract}
Dissertação apresentada à Faculdade de Zootecnia e Engenharia de Alimentos da Universidade de São Paulo, como parte dos requisitos para a obtenção do Título de Mestre em Ciências do programa em Gestão e Inovação na Indústria Animal.

Área de concentração: Gestão e Inovação na Industria Animal

Orientador: Prof. Dr. Adriano Rogério Bruno Tech
\end{abstract}

Data de aprovação:

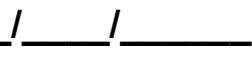

Banca Examinadora:

Prof. Dr. Adriano Rogério Bruno Tech (FZEA/USP)

Presidente da Banca Examinadora

Prof. ${ }^{a}$ Dr. ${ }^{a}$ Ana Carolina de Sousa Silva (USP/FZEA)

$2^{\circ}$ Examinador

Prof. Dr. Luis Arthur Malta Pereira (CUA)

$3^{\circ}$ Examinador 
Dedico esta obra a minha adorável e inesquecível mãe, a qual nunca se cansou de transmitir carinho, amor e educação. Onde quer que esteja, para sempre será lembrada.

Obrigado por tudo mãe! 


\section{AGRADECIMENTOS}

Aos meus pais, em especial a minha inesquecível mãe, que sempre me acolheu nos momentos difíceis. A minha esposa Gisele, por ter acreditado em minha pessoa e me incentivado a sempre olhar para frente e jamais me inclinar diante de qualquer dificuldade.

Ao meu orientador Prof. Dr. Adriano Rogério Bruno Tech, quem esteve ao meu lado na busca pelo melhor. Com sua paciência e disposição serviu como fonte de inspiração para alcançar meus objetivos.

Aos demais docentes e colegas de curso, que de uma maneira direta ou indireta fizeram parte da minha jornada e acreditaram no meu potencial. 
"Siga seu entusiasmo e o Universo abrirá portas onde antes só haviam paredes." Joseph John Campbell 


\section{RESUMO}

FAZZANARO, P. L. Avaliação dos protocolos ZigBee e IEEE 802.11ah através de simulação computacional para aplicação no agronegócio. 2016. $102 \mathrm{f}$. Dissertação (Mestrado) - Faculdade de Zootecnia e Engenharia de Alimentos, Universidade de São Paulo, Pirassununga, 2016.

A presença da tecnologia da informação dentro do agronegócio tem avançado e contribuído para a obtenção de melhores resultados para a gestão e, consequentemente, para o proprietário rural. Uma área de pesquisa que tem avançado dentro do setor rural é o monitoramento e a coleta de dados dos animais, em tempo real, possibilitando ao proprietário rural gerenciar seu rebanho, sem a necessidade de se deslocar ao local monitorado ou ao ponto de coleta de dados. A utilização das redes de sensores sem fio para fins de monitoração ainda possui limitações, como por exemplo a limitação do alcance do sinal de transmissão entre os nós sensores. Atualmente as tecnologias de transmissão de dados sem fio em uma rede de sensores alcançam pequenas distâncias, limitando o processo de detecção e coleta dos dados às áreas de pastagem menores. Assim, esta pesquisa teve como objetivo avaliar, através de simulação computacional, dois tipos de protocolos de comunicação sem fio que têm potencial para serem utilizados no monitoramento de sistemas de produção animal em longas distâncias: o protocolo ZigBee e o IEEE 802.1ah. Para a realização das simulações foram utilizados os softwares OMNet++ 4.5 e uma ferramenta de extensão chamada Mixim. Para tanto, foram criados dois cenários (ambientes) para cada protocolo, onde foram definidos: a área de cobertura, em torno de 1.500 metros, topologia da rede sem fio do tipo estática, dois nós para comunicação (um coordenador e um receptor) e as características do cenário. Por meio dos resultados obtidos através de simulação computacional com aplicação das métricas: distância, latência e taxa de perda de pacotes de dados nas simulações, observou-se que o protocolo ZigBee obteve o melhor desempenho em relação à distância de cobertura do sinal e da confiabilidade dos dados transmitidos.

Palavras-chave: agronegócio, redes de sensores sem fio, ZigBee, IEEE 802.11ah. 


\begin{abstract}
FAZZANARO, P. L. Evaluation of the ZigBee and IEEE 802.11ah protocols through computer simulation for application in agribusiness. 2016. 102 p. M.Sc. Dissertation - Faculdade de Zootecnia e Engenharia de Alimentos, Universidade de São Paulo, Pirassununga, 2016.

The presence of information technology within the agribusiness has advanced and contributed to better results for the management and, consequently, to the landowner. One area of research that has advanced into the rural sector is the monitoring and collection of animal data in real time, allowing the landowner to manage his herd, without the need to move to the monitored site or the data collection point. However the technology of wireless sensor networks used for this purpose, has limitations and one of them is the signals range factor because, in order to make the data collection is necessary to install sensors and antennas in the pasture to reach the signals. Currently, wireless data transmission technologies in a network of sensors reach short distances, limiting the detection process and data collect to smaller pasture areas. This study aimed to find a long-distance transmission solution to reach areas of larger proportions pastures, and offer the landowner new monitoring resources. The methodology used to find such a solution was through simulations, using two transmission technologies: ZigBee and IEEE 802.11ah. To perform the simulations it was used the OMNet++ software, version 4.5 and an extension tool, called the Mixim. It was created two scenarios (environments) for each protocol, where has been defined: the coverage area of about 1,500 meters, network topology wireless static type, two nodes for communication (a coordinator and a receiver) and the characteristics of the environment. Through the results obtained by computer simulation with application of the metrics: distance, latency and data packets loss rate in the simulations, it was observed that the ZigBee protocol had the best performance in relation to the signal coverage distance and the transmitted data reliability.
\end{abstract}

Keywords: agribusiness, wireless sensor networks, ZigBee, 802.11ah. 


\section{LISTA DE ILUSTRAÇÕES}

Figura 1 - Exemplo de uma estrutura de RSSF .............................................23

Figura 2 - Estrutura interna do nó sensor ....................................................24

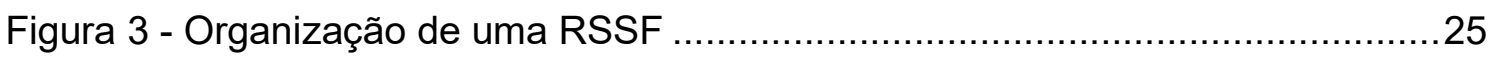

Figura 4 - Tipos de Nós Dispositivos em uma RSSF ......................................27

Figura 5 - Meios de comunicação sem fio ...............................................

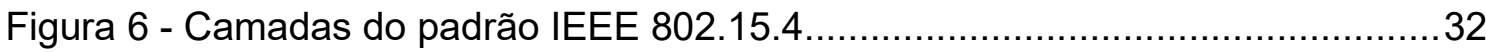

Figura 7- Frequências em uso para o padrão IEEE 802.11ah .............................37

Figura 8 - Envio e recebimento de pacote de dados entre Transmissor e Receptor.40

Figura 9 - Ambiente de desenvolvimento do OMNet++................................. 47

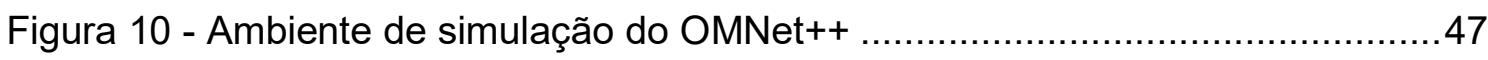

Figura 11 - Área de cobertura da RSSF simulada........................................49

Figura 12 - Posição dos Nós para medição...................................................55

Figura 13 - Área de inserção dos componentes .............................................56

Figura 14 - Ambiente de programação da simulação .......................................56

Figura 15 - Arquivo do resultado das simulações................................................. 58

Figura 16 - Dados relacionados ao arquivo de saída do OMNet++ ......................58

Figura 17 - Taxa de Perda de Pacotes do padrão ZigBee ...................................61

Figura 18 - Taxa de Perda de Pacotes do padrão IEEE 802.11ah.........................62

Figura 19 - Comparativo da TPP: ZigBee e IEEE 802.11ah ...............................63

Figura 20 - Latência do padrão ZigBee .....................................................66

Figura 21 - Latência do padrão IEEE 802.11ah ...........................................67

Figura 22 - Gráfico de comparação entre os padrões ZigBee e 802.11ah ..............69 


\section{LISTA DE TABELAS}

Tabela 1 - Padrões de Comunicação do IEEE ................................................ 29

Tabela 2 - Principais características do padrão IEEE 802.15.4 ............................33

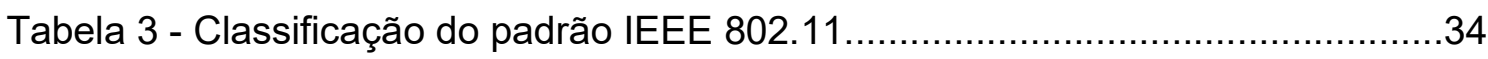

Tabela 4 - Comparativo entre o padrão ZigBee e Wi-Fi ......................................38

Tabela 5 - Definições dos módulos a serem simulados ....................................53

Tabela 6 - Média da Taxa de Perda de Pacotes ............................................60

Tabela 7 - Média da Latência do padrão ZigBee e IEEE 802.11ah.........................65

Tabela 8 - Comparativo da Latência entre ZigBee e IEEE 802.11ah ......................68 


\section{LISTA DE ABREVIATURAS E SIGLAS}

ACK: Acknowledgment

AM: Atraso Médio

ARQ: Automatic Repeat Request

CCK: Complementary Code Keying

CSMA/CA: Carrier Sense Multiple Access with Collision Avoidance

$\mathrm{dBm}$ : Decibel-milliwatt

DD: Direct Diffusion

DSSS: Direct Sequence Spread Spectrum

FEC: Forward Error Correction

FSBN: Floating Base Sensor Network

IEEE: Institute of Electrical and Electronics Engineers

IETF: Institute of Engineering Task Force

Gbps: Gigabits per second

GHz: Gigahertz

GPS: Global Position System

ITU-T: Telecommunication Standardization Union

Kbps: Kilobits per second

LMSC: Lan/Man Standards Committee

MANET: Mobile Ad-Hoc Network

Mbps: Megabits per second

NAK: Negative Acknowledgment

NC: Nó Coordenador

NED: Network Description

NR: Nó Roteador

NSC: Nó Sensor Comum

OSI: Open System Interconnection

PA: Ponto de Acesso

$R^{2}$ : coeficiente de determinação

RFC: Request for Comments

RFID: Radio Frequency Identification

RSSF: Redes de Sensores Sem Fio 
SPIN: Sensor Protocols for Information via Negotiation

TGah - Task Group ah

TPP: Taxa de Perda de Pacotes

TI: Tecnologia da Informação

valor-p: probabilidade de significância

VANT: Veículo aéreo não tripulado

WLAN: Wireless Local Area Network

WMAN: Wireless Metropolitan Area Network 


\section{SUMÁRIO}

RESUMO

ABSTRACT

LISTA DE ILUSTRAÇÕES

LISTA DE TABELAS

LISTA DE ABREVIATURAS E SIGLAS

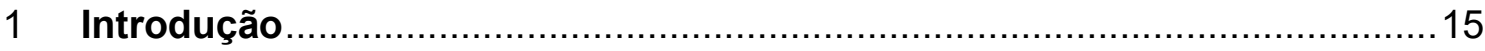

1.1 Zootecnia de Precisão........................................................................... 16

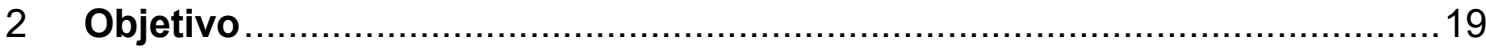

2.1 Objetivos Específicos .................................................................... 19

3 Tecnologias de comunicação aplicadas à agropecuária ........................20

3.1 Conceitos de Redes de Sensores Sem Fio.............................................20

3.1.1 Composição das Redes de Sensores Sem Fio .................................22

3.1.2 Componentes do Nó Sensor …....................................................24

3.1.3 Arquitetura e gerenciamento das Redes de Sensores Sem Fio ............25

3.1.4 Funções dos Nós em uma RSSF .............................................26

3.2 Meios de Comunicação Sem Fio aplicado às Redes de Sensores Sem Fio 28

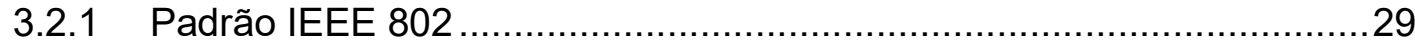

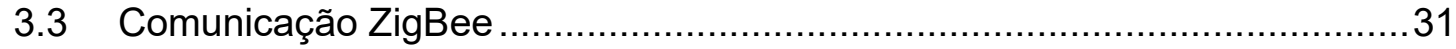

3.3.1 Padrão IEEE 802.15.4 - detalhes técnicos ........................................32

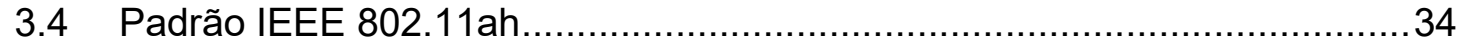

3.4.1 Protocolo IEEE 802.11ah - detalhes técnicos .................................36

3.5 Comparativo entre o padrão ZigBee e IEEE 802.11ah .............................37

3.6 Detecção e tratamento de erros para ambos os protocolos ........................39

3.7 Problemática das Redes de Sensores Sem Fio .................................... 41

3.8 Uso de plataformas de simulação de RSSF na agropecuária.....................42

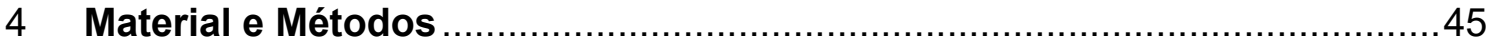

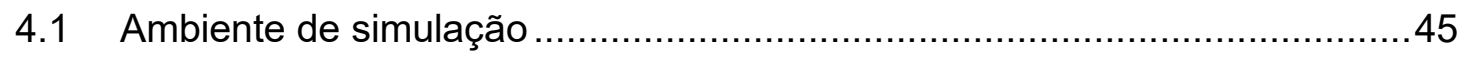

4.2 Descrição do software utilizado.......................................................... 46

4.2.1 Framework Mixim ................................................................. 48

4.3 Características do ambiente de simulação..........................................48

4.4 Procedimentos para medição do sinal .............................................50 


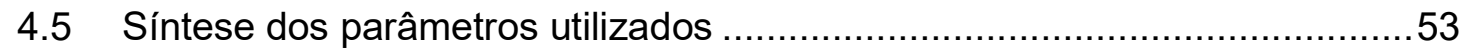

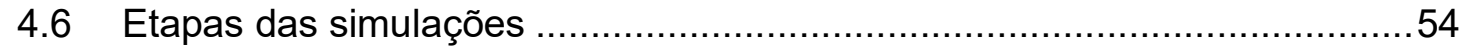

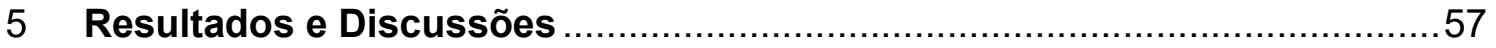

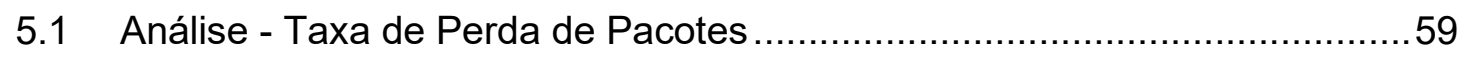

5.1.1 TPP - Comparativo entre os padrões de transmissão ..........................63

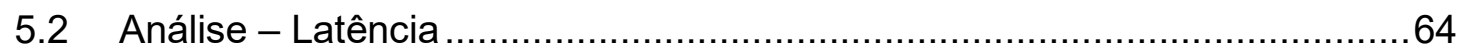

5.2.1 Latência - comparativo entre os padrões de transmissão......................67

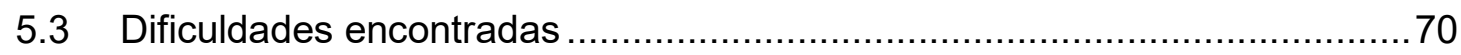

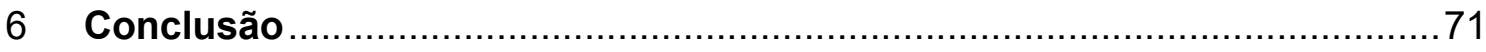

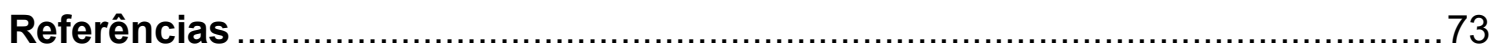

Apêndice A - Análise da taxa de perda de pacotes: ZigBee..................................79

Apêndice B - Análise da taxa de perda de pacotes: IEEE 802.11ah ........................84

Apêndice C - Regressão Linear da TPP para o padrão ZigBee ..............................89

Apêndice D - Regressão Linear da TPP para o padrão IEEE 802.11ah ..................90

Apêndice E - Análise da latência: ZigBee ..........................................................

Apêndice F - Análise da latência: IEEE 802.11ah ..............................................96

Apêndice G - Regressão Linear da latência para o padrão ZigBee.........................101

Apêndice H - Regressão Linear da latência para o padrão IEEE 802.11ah ............102 


\section{Introdução}

A inserção das tecnologias de informação e comunicação tem contribuído nos diversos segmentos do agronegócio, proporcionando ao profissional do ramo obter melhores resultados e gerenciamento de sua produção. Por meio do investimento em pesquisas científicas de caráter interdisciplinar, torna-se possível fazer com que a produção brasileira tenha uma importante participação no mercado externo.

Com o uso de recursos tecnológicos torna-se possível substituir rotinas e tarefas de serviços realizados de modo manual ou mecânico por um sistema informatizado. Por meio dos modelos computacionais e com a utilização de processos automatizados, tanto para equipamentos quanto para softwares, a ocorrência de falhas e de leituras inválidas tem reduzido o número de erros no gerenciamento das informações e ainda no custo de pessoal envolvido nas atividades.

Por outro lado, a implantação de soluções de tecnologia da informação no agronegócio se depara com algumas dificuldades, entre elas: condições climáticas; fatores geográficos (relevos, erosões); aspectos físicos e biológicos de plantas e animais. O desafio da agregação de recursos tecnológicos na agricultura e na pecuária está justamente em operar paralelamente um sistema informatizado com um sistema biológico, físico e químico. Para isso se faz necessário o investimento em pesquisas científicas interdisciplinares que viabilizem o emprego de recursos tecnológicos no campo.

Entre as diversas soluções tecnológicas em uso na agricultura e na pecuária, têm-se destacado ferramentas que auxiliam na rastreabilidade e no monitoramento eletrônico ambiental e animal, como por exemplo, a identificação por radiofrequência (RFID) e as redes de sensores sem fio (RSSF).

De acordo com Othman e Shazali (2012), o uso mais comum da tecnologia de RSSF é em ambiente externo, para auxiliar no monitoramento de rebanho, da pastagem, de plantações e mesmo de ambientes de produção, sem a intervenção humana no momento da coleta dos dados.

Com a exigência do mercado internacional nas exportações de grãos e carnes, somado à crescente procura por produtos de qualidade, por parte dos consumidores, tornou-se necessário investir em equipamentos e processos automatizados, que 
venham a contribuir na gestão das atividades tanto da pecuária como da agricultura, fornecendo ao seu administrador informações no menor tempo possível e com maior confiabilidade.

Entre as ferramentas que auxiliam o produtor no controle de suas atividades, o controle de ambientes e de processos têm ganhado força, uma vez que tem proporcionado uma redução no tempo de gerenciamento e de suporte à tomada de decisão sobre determinadas ações, principalmente as de coleta de dados e de gerenciamento de ambientes produtivos (SHUBEITA et al., 2012).

Assim, as RSSF têm reduzido o tempo de manejo e da coleta de dados fisiológicos dos animais e também das condições ambientais, como: a umidade e temperatura do ambiente, iluminação ou mesmo de leituras de determinados gases existentes no ambiente monitorado, que prejudicam e diminuem a produtividade animal, através de alterações fisiológicas no animal.

A implantação de uma RSSF no ambiente rural tornou-se possível devido à evolução dos equipamentos e das tecnologias a disposição dos profissionais. Estes têm trazido grandes benefícios, porém a sua implantação exige um planejamento mais elaborado e detalhado.

Deve-se levar em consideração algumas particularidades ao planejar sua instalação, como a dimensão da área a ser monitorada, as condições climáticas, o tipo do relevo, entre outras variáveis que poderão reduzir a eficiência da tecnologia utilizada.

Em razão da disponibilidade de vários protocolos de comunicação que podem ser utilizados em uma rede de comunicação sem fio, é relevante a realização de um estudo que defina qual é o protocolo mais adequado em relação ao consumo de energia e as condições ambientais, onde o mesmo será inserido.

\subsection{Zootecnia de Precisão}

Frente ao atual panorama do mercado da carne bovina, bem como em outros setores de produção, o consumidor tornou-se mais exigente e atuante em relação à procedência e a qualidade dos produtos alimentícios por eles consumidos.

Assim, torna-se necessário o uso de tecnologias que possam garantir ao consumidor o conhecimento e a procedência dos produtos ora adquiridos, com 
informações pertinentes e relacionadas à origem, tratamentos, manejos e outros elementos de importância para a caracterização do alimento.

Lala et al. (2013) relatam em seus estudos o perfil do consumidor tanto em nível nacional quanto internacional, e identifica que ambos os perfis têm mostrado constantes mudanças, sendo possível constatar, que atualmente ele está mais exigente quanto à qualidade do que consome, bem como em relação ao bem-estar animal e em relações com os aspectos ambientais. Além disso, o consumidor tem procurado conhecer os processos de criação e de abate dos animais (CHIZZOTTI; VALENTE, 2014).

O conceito de zootecnia de precisão tem como princípio fornecer técnicas e ferramentas de precisão que auxiliem na gestão dos processos (NAAS, 2011). O uso da zootecnia de precisão na pecuária e na indústria animal faz com que o produtor rural venha a se tornar um gestor de sua produção.

Porém, unificar tecnologia com a pecuária nem sempre é um processo simples, pois é importante ressaltar que a implantação de uma nova tecnologia deve estar de acordo com as questões ambientais, éticas, econômicas e biológicas. Para Naas (2011), deve ser dada maior ênfase ao bem-estar animal, pois algumas tecnologias utilizadas na zootecnia de precisão lidam diretamente com essa variável, e é preciso realizar um amplo estudo sobre a implantação de um novo modelo tecnológico dentro da pecuária.

Entre as diversas tecnologias oferecidas pela zootecnia de precisão, destacase a utilização do monitoramento remoto, em que é possível através de uma rede de sensores e antenas monitorar à distância um ambiente, seja ele externo ou interno. Um dos sensores mais empregados para esse fim, segundo Oliveira (2014) é o Global Position System (GPS) por se tratar de um dispositivo com capacidade de rastrear o deslocamento e a posição do bovino, porém seu custo é relativamente alto.

O GPS pode atuar em conjunto com a tecnologia RSSF para realizar o monitoramento dos animais em pastagem e das plantações em uma fazenda. Ambas tecnologias são objetos de pesquisas em diversas universidades, incluindo entre elas o campus da USP-FZEA em Pirassununga-SP. 
A aplicação da RSSF para uso na pecuária, fornece métodos automatizados para coletar e manipular dados fisiológicos, químicos ou biológicos de animais e da pastagem nos quais eles se alimentam. Nos estudos de Silva (2014) é analisado o uso das redes de sensores sem fio para medir e monitorar a interceptação luminosa nas pastagens, além disso com o uso dessa tecnologia torna-se possível fornecer ao proprietário rural a geolocalização dos animais monitorados.

Em se tratando de estudos do uso da RSSF na zootecnia, Tech (2008) fez uso das redes de sensores sem fio e de câmeras para auxiliarem na coleta de dados, monitoramento remoto de animais e de variáveis climáticas de ambientes de produção, bem como o armazenamento desses dados em um banco de dados, para futuro tratamento e suporte à decisão por parte dos profissionais responsáveis pela operação (pesquisadores ou gestores).

Para aprimorar ainda mais o sistema, Tech (2008) desenvolveu um e-Science ${ }^{1}$ para melhor gerenciar as atividades de manejos, controle de projetos e atividades produtivas, disponibilizando os dados a todos os envolvidos no projeto de maneira on-line.

Diante das soluções tecnológicas apresentadas tanto para a zootecnia como para a agricultura de precisão, constata-se que existem mecanismos para melhorar a produção rural e contribuir na gestão do que se produz. Porém, grande parte dos proprietários rurais desconhecem a existência desses recursos de tecnologia e informação.

É preciso aproximar os avanços tecnológicos dentro do setor rural, para possibilitar melhorias na produção, reduzindo perdas no cultivo, analisando a qualidade do solo, monitorando os animais em tempo real, dentre outros benefícios. Todavia, não basta ter todo aparato tecnológico, se a gestão e análise dos dados não forem realizadas de maneira correta.

\footnotetext{
1 e-Science: conjunto de informações sobre experimentos realizados para melhorias na pecuária brasileira e disponíveis através de uma base de dados, podendo ser compartilhado no meio científico e acadêmico (TECH, 2008).
} 


\section{Objetivo}

Este trabalho tem por objetivo avaliar a eficiência dos protocolos ZigBee e o IEEE 802.11ah empregados em ambientes de produção animal extensiva, utilizando simulação computacional.

\subsection{Objetivos Específicos}

- Criar e testar, através do software de simulação de redes de sensores sem fio OMNet++ ambientes externos experimentais, utilizando dois padrões de transmissão sem fio desenvolvidos para atuar nas RSSF: o ZigBee e o IEEE 802.11ah;

- Elaborar cenários virtuais para medir, através de simulações, o alcance do sinal de transmissão de dados dos nós sensores até o nó coordenador da uma rede de sensores sem fio. Medir a confiabilidade dos dados enviados, assim como a quantidade de pacotes perdidos que necessitaram ser retransmitidos;

- Averiguar o comportamento do padrão ZigBee já em uso nas RSSF e o mais recente padrão IEEE 802ah e determinar qual deles oferece melhor cobertura de comunicação para monitorar áreas rurais. 


\section{Tecnologias de comunicação aplicadas à agropecuária}

A vinculação da tecnologia com o agronegócio possibilita a abertura de novas oportunidades nesse setor da economia. Redução de custos operacionais, obtenção de um produto final com qualidade e monitoramento em tempo real do ambiente produtivo é algo desejável para profissionais que atuam nesse ramo. Assim, um estudo sobre as possíveis tecnologias de informação para aplicação no agronegócio torna-se possível levar até o produtor rural recursos e facilidades para melhor gestão do seu negócio, reduzindo o tempo nas análises dos dados e garantindo a confiabilidade dos mesmos.

\subsection{Conceitos de Redes de Sensores Sem Fio}

No modelo computacional, uma rede de computadores é caracterizada pelo uso de um concentrador, sendo este responsável por gerenciar e distribuir sinais entre os computadores que compõe o ambiente da rede. Este método, que depende de um meio que concentre as informações é de uso comum nas redes que utilizam cabos para a conexão entre os seus equipamentos, porém o mesmo não necessariamente faz parte de uma rede sem fio (FOROUZAN, 2008).

No campo das redes de sensores sem fio, Verona (2010) afirma que elas pertencem a uma subclasse das redes chamada ad hoc, isto quer dizer que se trata de uma tecnologia não centralizada de envio e recepção dos dados. Uma RSSF torna possível que qualquer nó da rede possa efetuar o roteamento dos dados, com capacidade para se tornar um transmissor e um receptor.

Uma Rede de Sensores Sem Fio (RSSF) é descrita como uma tecnologia de comunicação sem fio, capaz de monitorar um ambiente, seja ele interno ou externo, sem a intervenção humana, através de sensores capazes de medir grandezas físicas.

Segundo Zarpelon et al. (2015), a utilização da tecnologia RSSF no agronegócio tem auxiliado o proprietário rural a tomar decisões com base no monitoramento remoto em tempo real realizado pelos sensores que compõem essa tecnologia, dispensando nesse caso, o deslocamento de um indivíduo até o local que está sendo monitorado. 
Este tipo de rede tem como princípio coletar informações do ambiente, onde se encontram os sensores e transmitir os dados coletados por meio de um protocolo de comunicação e por rádio frequência para um sistema computacional que será o responsável pelo tratamento das informações (DANG; CHENG, 2014).

Além destas características, uma rede de sensores sem fio é homogênea, relativamente disseminada, com seus nós podendo atuar de maneira estática ou móvel e além do mais, possui alta densidade de sensores espalhados em um ambiente (RABER et al. 2013).

Esta tecnologia faz uso de nós sensores para coletar e transmitir as informações via comunicação sem fio do local onde encontram-se os sensores até um servidor de dados. Qutaiba (2013) ainda reforça que uma rede de sensores sem fio pode ser móvel ou estática, dependendo da aplicação para a qual ela foi elaborada.

Loureiro (2006) aponta que uma RSSF deve possuir algumas características diferentes de uma rede de computadores tradicional, ou seja, esta deve operar de modo autônomo, sem alimentação constante de energia. Além disso, esta rede é formada por dispositivos com pouca capacidade de processamento e potência para transmissão de sinal via rádio. Pesquisas realizadas por Adame et al. (2014), Henning (2013), Arce (2008) e Tech (2008), demonstram como esta tecnologia opera com o baixo consumo de energia e processamento limitado.

Uma RSSF se classifica como uma rede do tipo Mobile Ad-Hoc Network (MANET), o que implica dizer que se trata de uma rede descentralizada, não havendo necessidade de uma infraestrutura física para que ocorra a comunicação entre os meios. Uma característica importante desse tipo de rede, é que os nós que a compõem possuem a capacidade de autoconfiguração, já que não há um nó concentrador onde as informações se encontram (RABER et al., 2013).

Apesar do termo MANET ser adotado em uma rede de sensores sem fio, há diferenças em relação ao seu uso em uma rede composta por computadores e dispositivos móveis, as quais são:

- Densidade e quantidade de nós por área, podendo ser mais concentrado em relação a uma rede ad hoc tradicional;

- Muitos dos nós sensores podem estar posicionados em ambientes com muita variação de temperatura e umidade ou em locais hostis; devido às más condições, estes nós estão mais sujeitos a falhas; 
- Possui baixo poder de processamento, reduzindo com isso o consumo de energia e a capacidade de transmissão dos dados;

- Em geral, as RSSF são projetadas especificadamente para atender a necessidade do usuário que deseja implantá-la, não havendo neste caso um modelo pronto para ser comercializado (KAMRUDIN et al., 2010).

Devido às limitações e o propósito de uma RSSF, algumas modificações em termos de arquitetura são necessárias para que haja otimização e eficiência em sua funcionalidade (KHAN et al., 2011).

Com base nessas características apresentadas é importante mencionar que o objetivo principal de uma RSSF é medir - por meio de sensores - coletar os dados do meio em que se encontra e transmitir essas informações até uma central de análise de dados que realizará o processamento e o armazenamento devido.

\subsubsection{Composição das Redes de Sensores Sem Fio}

Ao projetar uma RSSF é necessário realizar um planejamento adequado e realizar uma análise detalhada do ambiente que será monitorado por sensores.

Com a evolução dos micro-sensores, acompanhada do desenvolvimento de micro-processadores e transceptores, tornou-se possível criar uma rede de sensores sem fio com diversas finalidades, como: monitorar, coletar dados, investigar e analisar determinado ambiente. As RSSF atualmente são apropriadas para uso militar, segurança, medicina, agricultura, pecuária, entre outros (SNAJDER; JELICIC; BILAS, 2014). 
A Figura 1 exibe um conceito geral da constituição de uma RSSF.

Figura 1 - Exemplo de uma estrutura de RSSF

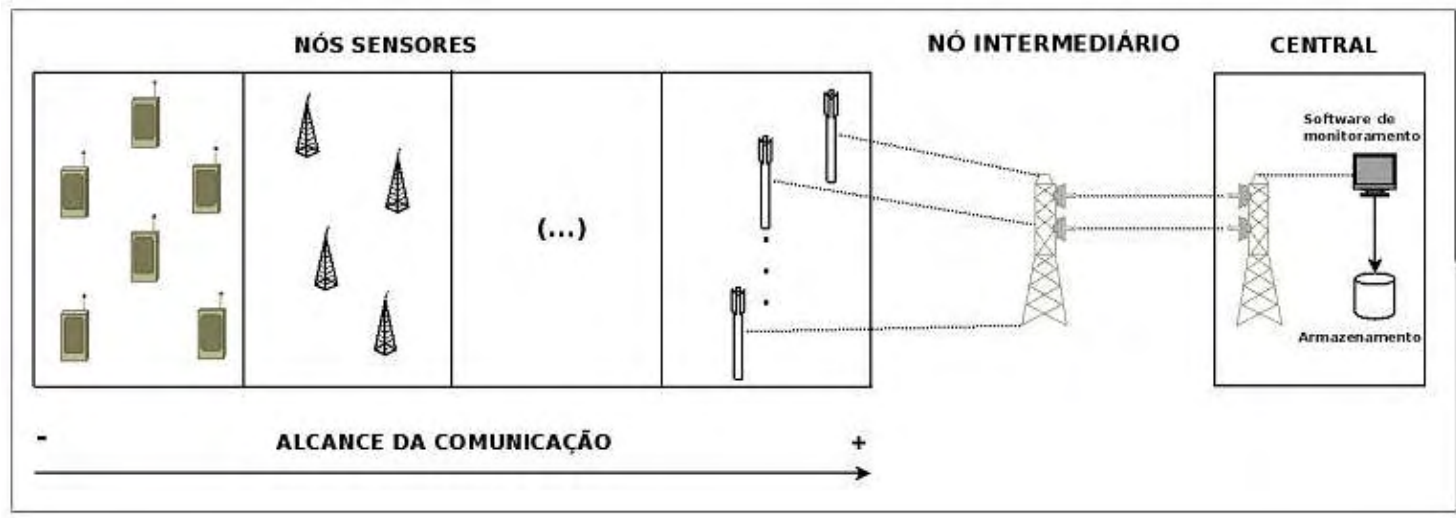

Fonte: SILVA, V. R. Uma Proposta para Automatização do Monitoramento da Interceptação Luminosa em Pastagens Utilizando uma Rede de Sensores sem Fio de Baixo Custo. 2014. 137 p. Dissertação (Mestrado) - Instituto de Informática da Universidade Federal de Goiás, Goiânia-GO, 2014.

Sob a óptica de Kaur e Talwar (2014) e Tilak et al. (2002), a tecnologia de RSSF é constituída por três elementos, os quais são:

- Micro-sensor: pequeno dispositivo eletrônico cuja função é realizar a monitoração física de um acontecimento no ambiente em que se encontra. Ao sofrer um estimulo físico ou químico (exemplo: temperatura, pressão, umidade) ele tem sua propriedade alterada e posteriormente trabalhará com estes dados coletados;

- Observador: é o sistema que receberá as informações disponibilizadas nas RSSF, sendo este o elemento interessado em coletar e analisar as informações que foram disponibilizadas pelo ambiente monitorado;

- Fenômeno: é a variável de interesse que o observador deseja avaliar. Estes fenómenos podem ser físicos ou químicos e diversos fenômenos podem atuar na mesma RSSF de modo concorrente.

Além dos elementos relatados, existem outros dispositivos que fazem parte de uma rede de sensores sem fios, entre eles: computadores, softwares para gerenciamento dos dados coletados, antenas para comunicação, GPS e RFID (OTHMAN; SHAZALI, 2012). 


\subsubsection{Componentes do Nó Sensor}

Um dos principais elementos que compõem uma RSSF são os nós sensores, os quais possuem em seu interior um transceptor, uma memória, um microcontrolador, sensores e bateria, conforme demonstrados na Figura 2.

Figura 2 - Estrutura interna do nó sensor

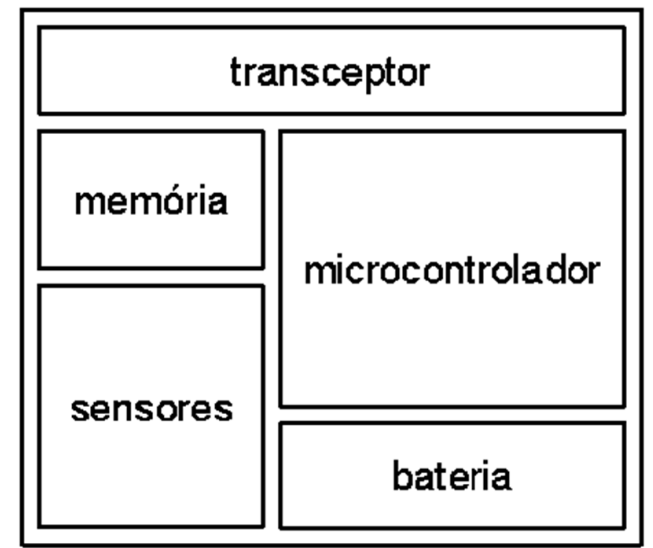

Fonte: LOUREIRO, A. A. F. Redes de Sensores Sem Fio. In: Conferência: Grandes desafios da pesquisa em computação para o período 2006-2016. 08-09 mai. 2006. São Paulo-SP.

Para Loureiro (2006) e Ruiz (2003), um nó sensor é composto pelos cinco elementos apresentados na figura 2, e a junção deles constitui um sistema computacional independente com capacidade para processar os dados capturados pelo sensor através de um micro-controlador. A memória armazena os dados temporariamente, enquanto a bateria é a responsável pelo fornecimento de energia para o nó sensor. $\mathrm{O}$ transceptor tem a função de realizar a transmissão dos dados pelo modo sem fio.

Além disso, o circuito integrado do nó sensor, pode ter como recurso a capacidade de receber informações relativas à intensidade do sinal de rádio recebido (RSSI) por meio da sensibilidade de recebimento e dos atributos da transmissão dos sinais eletromagnéticos, presentes nas redes de sensores. Por exemplo, os valores de RSSI são obtidos através da estimativa do nível de potência que o nó sensor recebe, e este valor é disponibilizado em Decibel-miliwatt (dBm), em um endereço de memória dos transceptores (TEXAS INSTRUMENTS, 2011). 


\subsubsection{Arquitetura e gerenciamento das Redes de Sensores Sem Fio}

No estudo promovido por Loureiro (2006), o autor esclarece que uma RSSF pode ser classificada como plana, na qual todos os elementos pertencentes a ela possuem as mesmas prioridades e qualquer um deles pode ter acesso ao Ponto de Acesso (PA) para enviar as informações. Outra classificação indicada por Raber et al. (2013) é o modo hierárquico, no qual é eleito um elemento para atuar como "coordenador", sendo este capaz de realizar o contato com um PA ou Estação Base, para em seguida transmitir todos os dados recebidos pelos nós comuns até um computador para fazer a análise dos dados.

No caso de uma rede de sensores sem fio para monitoramento das condições biológicas da pastagem de uma fazenda de criação de bovinos, por exemplo, é interessante utilizar o modo hierárquico, pois como os sensores são fixos, não há motivo para fazer uso do modo plano. Para melhor compreensão do assunto, a Figura 3 ilustra estas duas classificações abordadas, conforme Loureiro (2006).

Figura 3 - Organização de uma RSSF

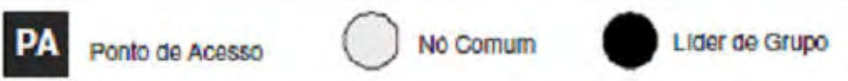

(a) RSSF hierárquica

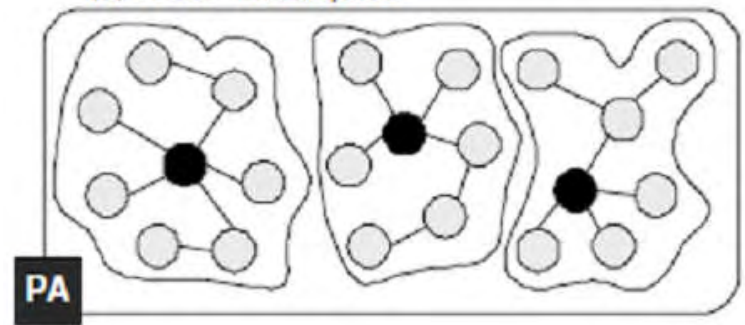

(b) RSSF plana

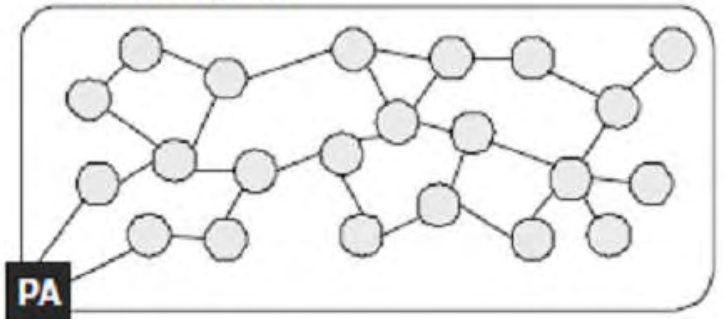

Fonte: LOUREIRO, A. A. F. Redes de Sensores Sem Fio. In: Conferência: Grandes desafios da pesquisa em computação para o período 2006-2016. 08-09 mai. 2006. São Paulo-SP.

Ao observar a imagem, nota-se que a RSSF hierárquica (a) dispõe de um nó coordenador (nó sink), que é o responsável pelo gerenciamento de outros nós sensores e pelo envio das transmissões até uma central de dados; enquanto que a RSSF plana (b) apresentada, caracteriza-se pelo fato de que nós comuns podem se tornar um nó com capacidade de transmissão de dados, exigindo assim um maior poder de processamento de cada nó na RSSF. 
Cada tipo de organização de rede de sensores sem fio contém protocolos de comunicação, que são responsáveis pelo encaminhamento correto dos dados coletados. Na topologia plana podem ser mencionados os protocolos: FBSN (Floating Base Sensor Network) utilizado por Arce (2008) em seu trabalho; SPIN (Sensor Protocols for Information via Negotiation) e DD (Direct Diffusion) proposto por Heinzelman e Kulik (1999).

Já para a topologia do tipo hierárquica, os seguintes protocolos podem ser utilizados: LEACH no qual Kaur e Talwar (2014) faz uso em trabalho; XMESH com aplicação nas pesquisas de Kodali e Sarma (2013); além do protocolo NSinks, apresentado por Balduíno e Rocha (2013).

As duas classificações abordadas possuem características próprias de funcionamento e cabe ao projetista da RSSF determinar qual delas será utilizada. Conforme foi comentado acima, cada organização possui seu respectivo protocolo e não há um consenso sobre qual delas é mais eficaz, pois depende do propósito desta.

De acordo com Sperque e Branquinho (2010), o modo de funcionamento de uma rede de sensores sem fio pode ser:

- Proativo: os nós sensores transmitem informações a todo instante;

- Reativo: os nós sensores somente transmitem mensagens quando há uma solicitação.

A escolha de um dos modos deve atender ao propósito da RSSF para o qual ela foi projetada, pois o uso incorreto de um dos modos pode comprometer sua eficácia e funcionalidade.

\subsubsection{Funções dos Nós em uma RSSF}

Como citado anteriormente, uma rede de sensores sem fio é constituída por vários dispositivos que possuem características distintas entre eles, mas que fazem parte de um conjunto como um todo. Verifica-se que os nós sensores apresentam três tipos e funções diferentes em uma RSSF, as quais são:

- Nó Coordenador (NC): conhecido também por Nó Sink ou Sorvedouro atua tanto em uma rede, utilizando o protocolo ZigBee ou IEEE 802.11ah. Este nó possui como função principal coordenar e gerenciar a comunicação com os demais nós da rede e faz o encaminhamento dos 
dados coletados até uma central computacional por internet ou outro meio disponível de transmissão de dados dentro da sua área de cobertura. Para cada RSSF criada, existe um coordenador, mas sua presença pode não ser essencial caso seja utilizada uma arquitetura plana da tecnologia de sensoriamento sem fio.

- Nó Roteador (NR): dispositivos com função de roteador, apresentam como característica principal a criação e o gerenciamento das melhores rotas de comunicação entre os nós sensores comuns. Possui algoritmos capazes de calcular as rotas com menos tráfego de dados ou mais próxima de si. Todo dispositivo denominado Nó Roteador necessita estabelecer conexão com um Nó Coordenador ou então com outro Nó Roteador, que por fim se irá conectar com o Nó Coordenador.

- Nó Sensor Comum (NSC): trata-se de um dispositivo final de uma RSSF podendo ser um nó sensor ou um atuador dentro dela. Não oferece capacidade de gerenciar outros nós e possui limitação em termos de hardware. É responsável pela coleta de dados e o envio destas até algum nó roteador ou nó coordenador (FRIAS, 2015).

A Figura 4 mostra a função de cada nó em uma rede de sensor sem fio.

Figura 4 - Tipos de Nós Dispositivos em uma RSSF
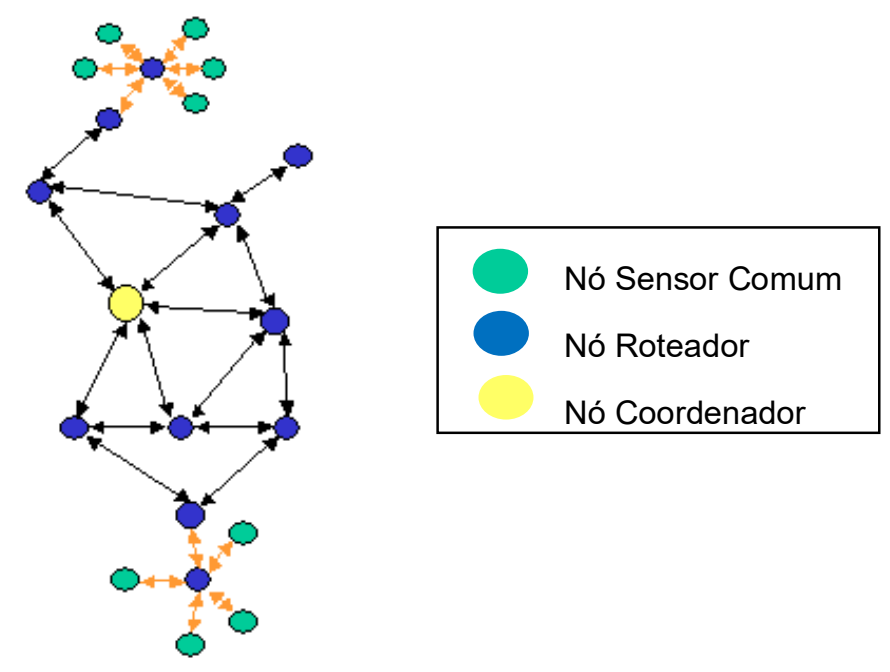

Fonte: Adaptado de FRIAS, R. N. ZigBee. Disponível em:

$<$ http://www.teleco.com.br/tutoriais/tutorialzigbee/default.asp>. Acesso em: 20. mai. 2015. 
Analisando a Figura 4 constata-se a função desempenhada por cada nó integrante de uma RSSF. Fica visível que existe apenas um Nó Coordenador (elipse de cor amarela), alguns nós roteadores (elipse de cor azul) e vários Nós Sensores Comuns (elipse de cor verde).

Cabe ao Nó Coordenador receber os dados coletados pelos NSC ou NR, agrupá-los e transmitir os dados até uma central de dados, como por exemplo um computador localizado em um escritório para que posteriormente este faça a análise dos dados.

Uma outra função que não foi citada, mas que acaba sendo essencial, é a capacidade dos nós poderem transmitir seus dados com segurança e garantir a integridade dessas informações. Normalmente o responsável pela segurança é o próprio Nó Coordenador que dispõe de mecanismos e algoritmos capazes de trabalhar com criptografia de 128 bits nos pacotes que circulam, em uma RSSF (RABER et al., 2013).

O modo como os recursos criptográficos funcionam em uma RSSF não faz parte do escopo deste trabalho, pois seria necessário realizar outras abordagens sobre criptografia envolvendo comunicação de dados.

\subsection{Meios de Comunicação Sem Fio aplicado às Redes de Sensores Sem Fio}

A maneira como uma informação é transmitida de um equipamento eletrônico para outro pode ser caracterizada de duas maneiras: com a utilização de fios e cabos ou por meio de comunicação sem fio (wireless). Entre os elementos envolvidos durante uma transmissão têm-se o transmissor e o receptor, que irão utilizar um dos mecanismos citados para trocarem dados entre si.

Em se tratando de comunicação via rede de computador, Arce (2008), Szilagyi e Herdon (2008) e Sigrimis et al. (1999) apontaram em suas pesquisas que o método sem fio é um dos mais eficientes para uso na agropecuária, graças ao seu modo de implantação e uso da transmissão sem fio.

Apesar de ser uma tecnologia que possui importante participação no meio rural, acaba se tornando um dos grandes desafios das RSSF; devido ao fato de que, dependendo da maneira como foram projetadas, encontram dificuldades na transmissão de informações entre os elos, em razão da distância geográfica dos nós 
que a constituem. Entre as dificuldades, destacam-se o consumo de energia e a potência dos aparelhos (QUTAIBA, 2013).

De acordo com Kurose e Ross (2012), para que a comunicação sem fio opere de modo satisfatório e livre de interferências é preciso antes de sua implantação, analisar quais protocolos e equipamentos serão empregados nas transmissões wireless. Para isso, órgãos como o Institute of Electrical and Electronics Engineers (IEEE) desenvolvem e estabelecem alguns padrões que podem ser utilizados nas diversas tecnologias de comunicação.

\subsubsection{Padrão IEEE 802}

O IEEE estabelece padrões internacionais de comunicação de dados para tornar possível o desenvolvimento de novos mecanismos de transmissão de informações. Entre os vários padrões criados por esse instituto, o IEEE 802 tem como principal característica a padronização das redes de computadores.

Sob a óptica de Sperque e Branquinho (2010), para compreender o funcionamento de uma rede de computador, seja ela com ou sem fio, criou-se na década de 80 um modelo de referência chamado OSI (Open System Interconnection). Este modelo é composto por sete níveis, onde cada nível possui funções específicas para tratar os dados que serão transmitidos em uma rede computacional.

Na Tabela 1 são apresentados os principais padrões de normas para diversas categorias de comunicação de dados em uso nas redes de computadores.

\begin{tabular}{ll}
\multicolumn{1}{c}{ Tabela 1 - Padrões de Comunicação do IEEE } \\
\hline Padrão 802 & \multicolumn{1}{c}{ Visão Geral e Arquitetura } \\
802.1 & Gerenciamento LAN e MAN \\
802.11 & Tecnologia Ethernet com sintaxe e semântica MAC \\
802.15 & Tecnologia de Redes Sem Fio \\
802.15 .4 & Rede de curto alcance sem fio (Bluettooth) \\
802.16 & Comunicação de curto alcance sem Fio ZigBee \\
802.20 & Tecnologia WIMAX para transmissão de dados \\
Fonte: TANENBAUM, A. S. Redes de Computadores. 5 ed. Rio de Janeiro:Elsevier, 2011.
\end{tabular}

Cada padrão apresentado tem suas próprias características e funcionalidade, permitindo que sejam utilizados nos mais diversos meios de comunicação. Entre os 
padrões apresentados, destacam-se o 802.11 e 802.15.4, que foram objetos de estudo desta pesquisa, por serem padrões que possibilitam atuar nas redes de sensores sem fio utilizado na zootecnia de precisão.

Sperque e Branquinho (2010) indicam que os meios de comunicação sem fio para o agronegócio dispõem de algumas tecnologias, com destaque para os padrões: Wi-Fi pertencente à família IEEE 802.11, Wimax, GPS, ZigBee, 802.11ah e RFID (Radio Frequency Identification). Dentre os padrões citados, alguns até 0 desenvolvimento deste trabalho ainda não tinham sido homologados para uso comercial, com por exemplo, o Wimax, 802.11ah. Porém, mesmo sem licença para uso comercial, esses modelos já são empregados no meio científico para analisar suas funcionalidades antes de serem oferecidos comercialmente.

$\mathrm{Na}$ Figura 5 é apresentado um gráfico, onde são exibidas as principais tecnologias sem fio em uso nas redes de sensores.

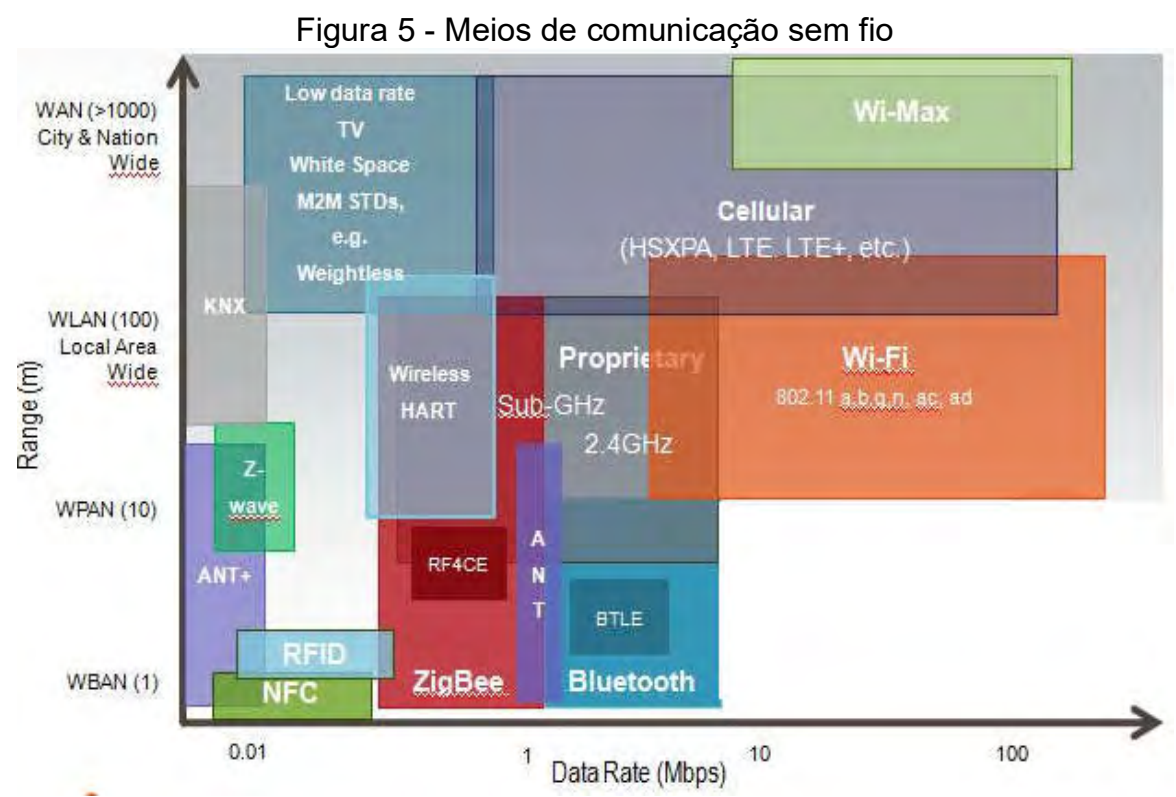

Fonte: HENNING, M. Protocolo de roteamento para redes de sensores sem fio baseado em políticas. 2013. 95 p. Dissertação (Mestrado) - Pontifícia Universidade Católica do Paraná, CuritibaPR, 2013.

É possível notar na Figura 5 que as tecnologias Wi-Fi e ZigBee possuem taxas de alcance semelhantes, conforme apresentado no eixo Y. Porém, em se tratando da medição da taxa de transferências por segundo, conforme indicado no eixo $X$ da mesma figura, o $\mathrm{Wi}-\mathrm{Fi}$ apresenta melhor resultado, podendo transferir acima de 100 Mbps (Megabits per second). 
Diversos pesquisadores atualmente fazem uso do padrão ZigBee para transmissão de dados em uma RSSF, entre eles Adame et al. (2014), Nadimi et al. (2012), Verona (2010) dentre outros. Entre os motivos para o uso do ZigBee como meio comunicador, destaca-se sua mobilidade, área de cobertura e, em especial, consumo de energia.

Além desse padrão, Balduino e Rocha (2013); Sun e Choi (2013) demonstraram em seus estudos, que o padrão IEEE 802.11ah apresenta benefícios interessantes em uma rede de sensores sem fio. Até o primeiro semestre de 2015 esse padrão não havia sido homologado para uso comercial, mas pesquisas e testes já foram sendo realizadas sob esta plataforma de transmissão de dados, para longa distância.

Por se tratar de uma tecnologia recente, este trabalho pretende expor o desempenho do padrão IEEE 802.11ah comparado ao ZigBee, por meio de simulações computacionais de RSSF, com o software de simulação OMNet++ versão 4.5 .

\subsection{Comunicação ZigBee}

Com o crescente número de aparelhos eletrônicos portáteis capazes de se comunicarem sem a necessidade de uma conexão fixa, a utilização de cabeamento tem diminuído cada vez mais e a demanda pela tecnologia de comunicação sem fio têm crescido. Para Messias (2014), as tecnologias sem fio têm seu emprego mais comum em redes locais (WLAN - Wireless Local Area Network) e, também em redes metropolitanas (WMAN - Wireless Metropolitan Area Network), em razão do número de usuários que fazem parte desse meio e da oferta de produtos.

A utilização dos padrões de transmissão sem fio em uso atualmente não tem como finalidade direta o emprego em uma RSSF, já que esta opera com algumas limitações como consumo de energia elétrica, sistema de baixa latência, grande quantidade de nós na rede, local de aplicação e outras particularidades, que serão abordadas mais adiante neste trabalho (KAUR; TALWAR, 2014).

O padrão ZigBee desenvolvido pela ZigBee Alliance tem como princípio oferecer solução para transmissão de dados em uma rede de sensores sem fio. $O$ ZigBee é um protocolo de comunicação que possibilita o monitoramento remoto de uma RSSF. 
O protocolo ZigBee não se aplica somente às redes de sensores sem fio. Seu campo de atuação inclui automação residencial e comercial, monitoramento e controle industrial, controle remoto de equipamentos eletrônicos, monitoramento remoto de pacientes, comunicação entre periféricos de computador, dentre outras aplicações (DANG; CHENG, 2014).

O que torna importante a utilização do protocolo ZigBee como meio de transmissão, é que os dispositivos que o constituem podem permanecer ociosos na ausência de atividade, além de operarem com um número reduzido de pacotes de dados.

\subsubsection{Padrão IEEE 802.15.4 - detalhes técnicos}

Desenvolvido a partir do padrão IEEE 802.15, o modo ZigBee atende a um conjunto de especificações de funcionamento, sofrendo algumas adaptações para que possa funcionar a partir de um baixo consumo de energia e taxas de transmissões reduzidas. A maneira pelo qual os equipamentos que usam este padrão se comunicam ocorre por meio de camadas, onde cada uma delas troca dados com a camada inferior e superior.

No modelo tradicional de uma rede de computadores existem sete camadas que viabilizam a comunicação entre máquinas, já no padrão IEEE 802.15.4, pertencente ao ZigBee são cinco camadas, conforme apresentado na Figura 6.

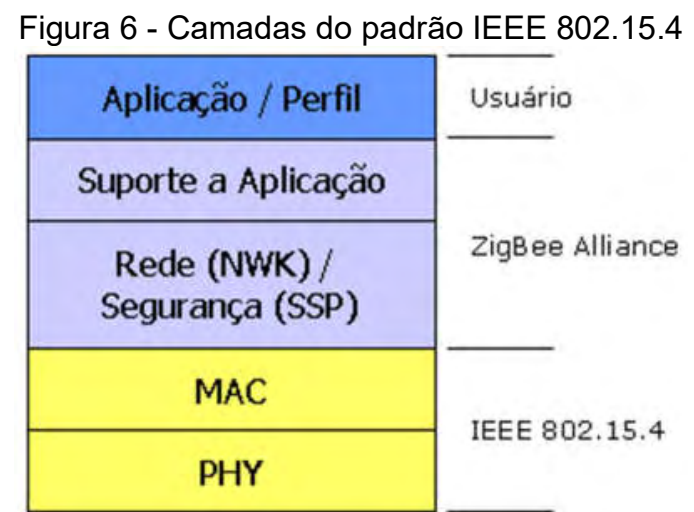

Fonte: Fonte: Adaptado de FRIAS, R. N. ZigBee. Disponível em:

<http://www.teleco.com.br/tutoriais/tutorialzigbee/default.asp>. Acesso em: 20. mai. 2015.

Ao observar a Figura 6, pode-se verificar que as camadas MAC e PHY são definidas pelo IEEE. Já as camadas Rede (NWK) e Segurança (SSP) foram 
implementadas pelo ZigBee Alliance. Por último, a camada de Aplicação/Perfil que contêm especificações conforme a necessidade do usuário que desenvolverá os serviços nessa respectiva camada (FRIAS, 2015; RIBEIRO, 2015).

Entre as camadas comentadas, a de Rede possui um importante papel para uso em redes de sensores sem fio, pelo fato de que ela suporta topologias do tipo estrela, árvore e mista (Younis et al., 2014). Essas topologias determinam de que maneira os sensores de uma RSSF irão interagir e se comunicar e o uso incorreto pode tornar instável o serviço oferecido pelas redes de sensores sem fio.

O documento sobre o padrão 802.15.4 emitido pelo IEEE, apresenta em seu conteúdo outros detalhes desse padrão. Além das camadas já citadas anteriormente, resumidamente destacam-se algumas características relevantes, como pode ser observado na Tabela 2, obtidas das especificações deste padrão:

Tabela 2 - Principais características do padrão IEEE 802.15.4

\begin{tabular}{lll}
\hline \multicolumn{1}{c}{ Frequências } & \multicolumn{1}{c}{ Número de Canais } & \multicolumn{1}{c}{ Taxa de Dados } \\
\hline $2.4-2.4835 \mathrm{GHz}$ & $16(11$ a 26$)$ & $250 \mathrm{kbits} / \mathrm{s}$ \\
$868-870 \mathrm{MHz}$ & $1(0)$ & $20 \mathrm{kbtis} / \mathrm{s}$ \\
$902-928$ & $10(1 \mathrm{a} 10)$ & $40 \mathrm{kbtis} / \mathrm{s}$ \\
\hline
\end{tabular}

Fonte: Adaptado de Institute of Electrical and Electronics Engineers - IEEE. IEEE Std 802.11 - specific requirements. IEEE Standard for Local and Metropolitan Area

Networks: Overview and Architecture. IEEE; 2014. (Revision to IEEE Std. 802 - 2001).

Conforme apresentado na Tabela 2, quanto maior a frequência utilizada maior será a taxa de dados que será transmitida sobre ela e, também terá à disposição um maior número de canais para uso. Mas, segundo Tanenbaum (2011), quanto maior a frequência a ser utilizada, mais problemas de interferência ocorrerão e o alcance do sinal será limitado em uma transmissão que utilize o meio sem fio como propagação.

O motivo que leva diversos pesquisadores a incorporarem o padrão ZigBee para realizar a comunicação de dados entre os nós sensores e coordenadores, se deve ao fato das características já apresentadas, com destaque para o baixo consumo de energia e de sua taxa de transmissão. Além do mais, este padrão oferece forte imunidade em relação às interferências e conta com suporte para mais de 65000 mil nós sensores (NADIMI et al., 2012). 
A otimização e agilidade em obter os dados coletados por cada sensor através de um meio de comunicação torna possível analisar dados em tempo real e com precisão (ZIGBEE ALLIANCE, 2015).

\subsection{Padrão IEEE 802.11ah}

Para que uma tecnologia de transmissão sem fio funcione adequadamente é necessário obedecer um padrão. Para esse modo de comunicação não guiado o IEEE criou o padrão Wi-Fi ou IEEE 802.11, que advêm de um grupo chamado IEEE 802 Lan/Man Standards Committee (LMSC) específico para as redes locais sem fio.

De acordo com Tanenbaum (2011) existem alguns padrões criados pelo grupo IEEE 802 LSMC, os quais são categorizados conforme suas respectivas funcionalidades e usabilidade. A Tabela 3 apresenta algumas das variantes do padrão 802.11 estabelecido pelo IEEE:

Tabela 3 - Classificação do padrão IEEE 802.11

(continua)

Norma Descrição

Opera com frequência de $5 \mathrm{Ghz}$ (Gigahertz), com alcance em torno

802.11a de 50 metros e possui taxa de transferência na casa dos 54 Mbps. Utiliza a técnica OFDM no envio das informações.

Tem como característica uma taxa de transferência de dados de 11

$802.11 b$ Mbps em média, além disso trabalha na frequência $2,4 \mathrm{GHz}$ e possui como método de envio de dados o modo Direct Sequence Spread Spectrum (DSSS) e Complementary Code Keying (CCK).

Atualmente é o sucessor do padrão $802.11 \mathrm{~b}$ e apresenta taxas de

$802.11 \mathrm{~g}$ transmissão de 54 Mbps operando na frequência de $2,4 \mathrm{GHz}$. Possui cobertura de aproximadamente 400 metros e faz uso da técnica OFDM para envio das informações.

Sua principal característica se chama MIMO, sendo uma técnica que promove uma melhoria na transferência dos dados. Sucesso do

$802.11 \mathrm{n} \quad 802.11 \mathrm{~g}$, esse padrão pode atingir até $600 \mathrm{Mbps}$ operando nas faixas de 2,4 a $5 \mathrm{GHz}$. Sua técnica de transmissão é conhecida por MIMO-OFDM.

Padrão em desenvolvimento que será o sucessor do $802.11 \mathrm{n}$.

$802.11 \mathrm{ac}$ Apresenta como característica taxa de transmissão nominal de 6 Gbps (Gigabits per second), através de multicaminhos de transmissão). Opera na frequência de $5 \mathrm{GHz}$ e faz uso da técnica de envio chamada MU-MIMO. 
Tabela 3 - Classificação do padrão IEEE 802.11

(conclusão)

\begin{tabular}{|c|c|}
\hline Norma & Descrição \\
\hline 802.11ah & $\begin{array}{l}\text { Em fase de homologação, este padrão tem como especificação } \\
\text { uma taxa de transferência de } 100 \mathrm{Kbps} \text { (Kilobits per second) e } \\
\text { opera na frequência de } 902-928 \mathrm{MHz} \text { no Brasil. Sua área de } \\
\text { cobertura chega a atingir até } 1 \text { quilometro em campo aberto. Seu } \\
\text { foco é a economia de energia e um alcance maior do sinal em } \\
\text { relação a outros padrões utilizados em RSSF. }\end{array}$ \\
\hline
\end{tabular}

Fonte: Adaptado de Institute of Electrical and Electronics Engineers - IEEE. Official IEEE 802.11

working group project timelines - 2015-05-26: in process - Standards, Amendments, and

Recommended Practices. Disponível em: http://www.ieee802.org/11/Reports/802.11_Timelines.htm.

Além das normas citadas, existem outras que são evoluções das já apresentadas ou que contém alguma modificação para um determinado propósito (FOROUZAN, 2008).

Segundo Nadimi et al. (2012), o método Wi-Fi faz parte de uma gama de meios de comunicação sem fio, específicos para aplicações de sensoriamento que exigem esse tipo de comunicação. Além do Wi-Fi, outros métodos como ZigBee e Bluetooth também são empregados em uma rede de sensoriamento sem fio.

A escolha de um modelo especifico de transmissão de dados para uma rede de sensores depende de cada projeto, pois cada rede possui características particulares e a escolha do método mais adequado advém de simulações e testes antes mesmo da aquisição de toda a infraestrutura.

Dentro da gama de padrões derivados do IEEE 802.11, o 802.11ah fornece recursos específicos para implementação de um sistema de RSSF na agricultura de precisão. A otimização no consumo de energia, amplitude do raio de cobertura e rápida convergência são alguns dos pontos fortes dessa tecnologia e propagação de sinal aperfeiçoado (BALDUINO; ROCHA, 2013).

Como já exposto anteriormente, o padrão ZigBee é um dos modelos de comunicação mais utilizados nas redes de sensores sem fio, porém com a entrada do 802.11ah no mercado haverá um leque maior de soluções de tecnologia de transmissão sem fio. Cabe destacar que o padrão IEEE 802.11ah ainda se encontra em processo de aprovação, o qual deverá ser liberado para uso comercial no primeiro semestre de 2016 segundo próprio relatório do IEEE (IEEE, 2015). 


\subsubsection{Protocolo IEEE 802.11ah - detalhes técnicos}

Balduino e Rocha (2013), bem como Sun e Choi (2013) esclareceram que um grupo de pesquisadores que atende pela sigla TGah (Tadsk Group ah), remodelaram as camadas Física (PHY) e Enlace (MAC), baseada no padrão IEEE 802.11ac, para que o rendimento da rede e a distribuição da frequência portadora sub $1 \mathrm{GHz}$ fosse possível.

Este padrão opera de modo independente em relação aos outros padrões da categoria 802.11, tendo capacidade de distribuir sinal com distância superior em relação às frequências adotadas pelos padrões 802.11 , como $2.4 \mathrm{GHz}$ e $5 \mathrm{GHz}$ (IEEE 802 std, 2013). Por operar com uma frequência relativamente baixa, Aust e Ito (2011) apontaram que isto acaba se tornando um fator relevante para o emprego em redes de sensores sem fio, pois o raio de alcance de uma frequência baixa é mais abrangente.

As modificações realizadas na camada MAC do respectivo padrão para aumentar a eficácia no consumo de energia ainda não apresentaram bons resultados, fazendo disto um ponto crítico a ser analisado antes de sua implantação (SUN; CHOI, 2013).

Com referência à camada física está dividida em duas pequenas categorias as quais correspondem ao modo de transmissão, sendo a primeira categoria especifica para transmissões que utilizam canal maior ou igual a $2 \mathrm{MHz}$ e outra categoria para canais abaixo de $1 \mathrm{MHz}$ de largura de banda (GRANJAL; MONTEIRO; SILVA, 2015).

Em relação à faixa de frequência utilizada pelo 802.11ah, ADAME et al. (2014) relataram que estas sofrem variações dependendo do país e do continente, conforme pode ser observado através da Figura 7. 
Figura 7 - Frequências em uso para o padrão IEEE 802.11ah

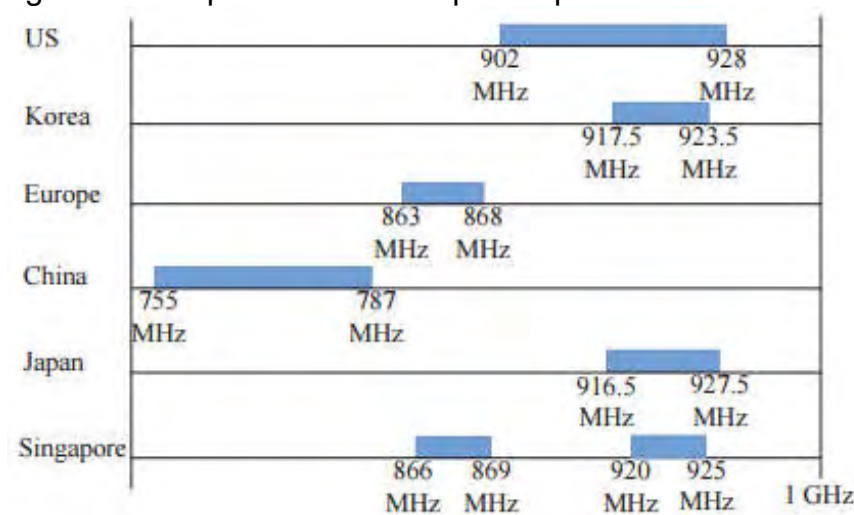

Fonte: SUN, W.; CHOI, M. IEEE 802.11AH: A Long Range 802.11 WLAN at Sub 1GHz. Journal of ICT Standardization, v. 1, p 83-108, Seoul, 14 may. 2013.

Conforme mostrado na Figura 7, pode-se verificar que as faixas adotadas por alguns países são semelhantes, como por exemplo Japão e Coréia. De acordo, com Balduino e Rocha (2013), a faixa licenciada para uso do IEEE 802.11ah, no Brasil, corresponde ao intervalo de 902 - $928 \mathrm{MHz}$, ou seja, o mesmo espectro dos Estados Unidos.

A baixa frequência oferece um gasto energético menor para transferência de dados, reduz o nível de ruído do sinal e permite cobrir uma área aberta maior, como por exemplo, a pastagem de grandes fazendas (KHAN et al., 2011). Por consequência dessas características comentadas, torna-se importante averiguar o comportamento deste padrão atuando em uma RSSF.

\subsection{Comparativo entre o padrão ZigBee e IEEE 802.11ah}

Tanto o ZigBee quanto o IEEE 802.ah são padrões de comunicação para atuarem nas RSSF, mas com mecanismos de funcionamento diferente um do outro. Segundo KHAN et al. (2012), ambos os padrões favorecem o uso para o monitoramento remoto de animas e plantações, porém cada uma possui suas particularidades conforme apresentado na Tabela 4. 
Tabela 4 - Comparativo entre o padrão ZigBee e Wi-Fi

\begin{tabular}{lll}
\hline \multicolumn{1}{c}{ Especificações } & \multicolumn{1}{c}{ ZigBee } & \multicolumn{1}{c}{ IEEE 802.11ah } \\
\hline Especificação IEEE & 802.15 .4 & $802.11 \mathrm{ah}$ \\
Frequência de banda & Brasil $(2,4 \mathrm{GHz})$ & Brasil $(902-928 \mathrm{MHz})$ \\
Largura de banda de canal & $2 \mathrm{MHz}$ & $1 / 2 / 4 / 8 / 16 \mathrm{MHz}$ \\
Taxa de transferência & $250 \mathrm{Kbps}$ & $100 \mathrm{Kbps}$ \\
Área de cobertura do serviço & 10 a 100 metros & 800 metros \\
Quantidade de estações suportadas & 68000 & 8000 \\
\hline
\end{tabular}

Fonte: BALDUINO, J. O.; ROCHA, M. N. Simulação de uma rede de sensor sem fio com base nos padrões zigbee e ieee 802.11ah. InterSciencePlace: Revista Científica Internacional. ed. 25, v. 1, art. P. 148, abr. jun. 2013.

Segundo Balduino e Rocha (2013), um dos principais fatores que diferem as duas tecnologias está relacionado à área de cobertura em que o sinal de transmissão é capaz de cobrir. Observa-se que no padrão 802.11ah, a área de cobertura é relativamente maior em relação ao ZigBee, porém são valores nominais e não está sendo considerado o uso de equipamentos que possam potencializar o sinal de ambos os padrões, permitindo cobrir uma área mais ampla.

Um outro dado exibido na Tabela 4 e que merece atenção é a quantidade de estações suportadas, isto é, o número de sensores que uma RSSF pode suportar, utilizando uma das tecnologias. Fica constatado que o padrão ZigBee, consegue operar com até 68000 estações, já o 802.11ah com apenas 8000 (KHAN et al., 2011).

Em relação à confiabilidade e segurança na entrega dos dados transmitidos entre elementos da rede de sensor sem fio, ambos os padrões possuem recursos como criptografia de dados, mecanismo para evitar o envio de informações redundantes, verificação de erros e autenticação dos dispositivos (DANG; CHENG, 2014)

Somente analisando as características e valores de cada padrão, torna-se difícil estabelecer qual deles possui relação custo e benefício mais atraente para o agricultor que deseja implantar um sistema de redes de sensores sem fio para sua plantação ou criação de animais. Para isso, é necessário realizar alguns experimentos com os dois padrões para determinar qual obtém melhor desempenho.

A proposta desta pesquisa foi a realização de simulações tanto com o ZigBee quanto com o IEEE 802.11ah e a verificação de qual deles possui melhor comportamento, atuando em uma rede de sensores, em uma área de cobertura que possa atender as necessidades do agricultor, através de simulação computacional. 


\subsection{Detecção e tratamento de erros para ambos os protocolos}

Tanto o padrão IEEE 802.11ah quanto o IEEE 802.15.4 possuem nas camadas inferiores (Física e Enlace) algoritmos para tratamento de erros, defeitos e verificações das informações transmitidas dentro do pacote de dados entre transmissor e receptor. Para garantir que um dado enviado mantenha suas características, assim que chega ao receptor, ambos os protocolos oferecem soluções.

A camada MAC além de permitir a identificação dos nós sensores em uma RSSF, também dispõe de um mecanismo chamado Carrier Sense Multiple Access with Collision Avoidance (CSMA/CA), para evitar a colisão de dados entre os nós na rede, durante a transmissão dos dados (DELISLE, 2015).

Ao utilizar esse método, todo equipamento que pertence a uma rede sem fio e que deseja transmitir um pacote de dados, primeiramente deve verificar se o meio de comunicação está livre e caso esteja, o transmissor informa aos outros dispositivos sobre a sua transmissão, bem como o seu tempo de duração. Desta forma, evita-se que dois ou mais equipamentos transmitam informações durante o mesmo intervalo no qual o transmissor está enviando a informação (KUROSE; ROSS, 2012).

Outros dois protocolos que atuam na camada MAC de uma rede de sensores sem fio são: o Automatic Repeat Request (ARQ) e o Forward Error Correction (FEC). Ambos os protocolos permitem realizar o controle de erros e a retransmissão dos dados. Entretanto, o protocolo $A R Q$ opera com pacotes especiais de dados durante o processo de transmissão das informações e o FEC faz uso de códigos corretores e despacha as informações de modo redundante.

Para compreender o funcionamento básico dos protocolos $A R Q$ e FEC, a Figura 8 exibe o processo de envio e recebimento de pacotes de dados entre os nós sensores. 
Figura 8 - Envio e recebimento de pacote de dados entre Transmissor e Receptor

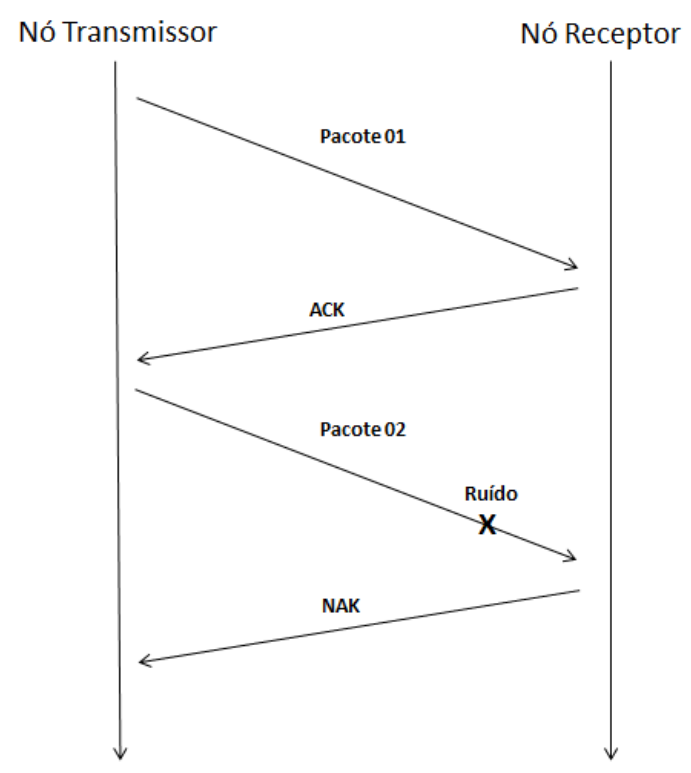

Fonte: Própria autoria.

Observa-se que os pacotes enviados pelo nó transmissor são recebidos pelo nó receptor. Após o recebimento correto e livre de erros, o receptor enviará um pacote especial, chamado Acknowledgment (ACK), que informará ao transmissor que não houve problemas com os dados e com isso, o transmissor poderá transmitir o próximo pacote. Se houver alguma falha no envio dos dados - como um ruído eletromagnético, por exemplo, o receptor avisará ao transmissor por meio de um pacote especial, conhecido por Negative Ackownledgment (NAK), que houve erro durante a transmissão e assim, o mesmo será reenviado (LIN et al.; 2012).

De acordo, com Lin et al. (2012) e Tanenbaum (2011), os dois protocolos apresentam efeitos colaterais. No protocolo $A R Q$, o problema se encontra no alto overhead (processo ou armazenamento em excesso) gerado pela retransmissão dos pacotes. Já o protocolo FEC apresenta certo grau de complexidade para ser decodificado e, geralmente necessita de um circuito dedicado para seu funcionamento. 


\subsection{Problemática das Redes de Sensores Sem Fio}

Diversos estudos e pesquisas foram realizados com a finalidade de tornar as RSSFs mais eficazes e econômicas para o uso no agronegócio. Segundo Henning (2013) apesar do surgimento de novos softwares e equipamentos de auxilio no sensoriamento em locais abertos - como por exemplo uma fazenda de criação de gado - há ainda outros desafios, como:

- Consumo de Energia: apontado por Henning (2013) e, Kaur e Talwar (2014) um dos principais desafios das RSSF se concentra no consumo de energia que os componentes - sensores e seus circuitos eletrônicos - de uma RSSF realizam. As baterias que alimentam os dispositivos precisam ter autonomia suficiente para operar o máximo de tempo possível sem a necessidade de recarga.

- Meio de Transmissão: fundamental para o funcionamento de uma RSSF, pois os dispositivos presentes devem possuir capacidade para transmitir informações por meio de ondas de rádio frequência. Entre as principais tecnologias de transmissão de dados empregados atualmente em RSSFs encontram-se o Bluetooth, ISSO 11783, IEEE 802.11ah e o protocolo ZigBee. A escolha do meio de transmissão tem influência direta no consumo de energia (ADAME et al., 2014) e também na confiabilidade dos dados que foram transmitidos.

- Confiabilidade: devido à não intervenção humana, os sensores devem ser capazes de manter suas características e funcionalidades. Outro ponto que possui relação com a confiabilidade é o uso de protocolo de comunicação, que assegura a relação da quantidade de dados transmitidos e recebidos e o controle de retransmissão dos mesmos em caso de problemas de transmissão.

- Tráfego de Dados: para Henning (2013) e Carvalho et al. (2012), a redução do tamanho dos dados auxilia no funcionamento da RSSF, já que esta é composta por inúmeros sensores e com isso há chances de ocorrer tráfego demais na rede, gerando congestionamento e como consequência, informações serão perdidas. Entre as soluções, Carvalho et al. (2012) 
enaltece o uso da computação para realizar a agregação ou a fusão dos dados dentro das redes de sensores, para em seguida serem transmitidos.

Entre os principais entraves que enfrenta uma RSSF estão os sinais de rádio que permitem que ocorra a comunicação entre os nós sensores da rede, influenciando diretamente nos itens citados acima. O rádio transmissor dos nós da RSSF consome energia e é constantemente afetado por fenômenos como reflexão e difração de onda, linha de visada e distância física entre antenas, inclinação da crosta terrestre, condições climáticas adversas como chuva, neblina, etc. (TANENBAUM, 2011).

Constata-se que há diversos fatores que necessitam ser analisados ao projetar uma RSSF para um cliente, porém, deve-se priorizar o desempenho e a confiabilidade das informações. Como já comentado, uma RSSF atende a um propósito especifico de quem deseja implantá-la, não havendo um modelo pronto disponível. É comum neste caso, realizarem-se simulações e testes em uma plataforma - software - que reproduz o local onde a RSSF será criada (SUN; CHOI, 2013).

\subsection{Uso de plataformas de simulação de RSSF na agropecuária}

A simulação da tecnologia RSSF para uso na agricultura e pecuária por meio de um software de simulação se faz necessária devido à complexidade e a dinâmica para implantar e colocar em funcionamento uma rede de sensoriamento para coleta de dados. Como comentado anteriormente, são muitos os fatores que podem ou não inviabilizar o uso real de uma RSSF no agronegócio.

Ainda que a relação custo e benefício seja utilizada como parâmetro para adotar tal recurso, é preciso analisar outras variáveis que esta rede pode assumir e investigar a viabilidade em sua adoção (ADAME et al, 2014).

Para auxiliar na análise do comportamento de uma RSSF, Raber et al. (2013); Verona (2010) enfatizaram e fizeram uso de ferramentas para simular diversos cenários e ambientes próximos à realidade, em seus estudos voltados para a agricultura de precisão.

Um estudo interessante foi elaborado por Costa (2013) envolvendo o uso de redes de sensores sem fio e veículo aéreo não tripulado (VANT), fazendo uso do 
software de simulação OMNet++ para avaliar a eficiência da aplicação de defensivos químicos depositados no solo. Já Kamarudim (2010), Silva (2014) e Qutaiba (2013) contextualizaram a usabilidade de ferramentas especificas para simular redes de sensores sem fio nos mais diversos ramos de negócios.

Nota-se que existem várias pesquisas e estudos que adotam a simulação por softwares quando se pretende analisar a implantação de uma RSSF, seja na agricultura ou na pecuária de precisão. Por se tratar de soluções recentes, o gestor do setor agropecuário e da indústria animal observa tais recursos tecnológicos com receio, devido ao alto investimento na tecnologia em questão.

Uma das propostas para reduzir custos é a possibilidade de simular utilizando software, o ambiente que precisa ser monitorado via RSSF. Considera-se a vantagem de que a simulação auxilia na análise de outros fatores que vão além do investimento na tecnologia, conforme constatado nos estudos apreciados anteriormente.

Entre os softwares de simulação para redes de sensores sem fio, destacam-se o Simulator for Network Algorithms (Sinalgo), Network Simulator 2 (NS-2) e o OMNet++. Cada um desses softwares permite programar ambientes de simulação para as RSSF, porém cada plataforma é configurada de modo diferente.

A seguir são apresentadas as principais características de cada plataforma de simulação comentada no parágrafo anterior:

- NS2: é um software simulador de código aberto para realizar eventos discretos em redes de computadores. Gitel e Sharma (2012) reforçam em seus estudos que é possível realizar diversas simulações com vários protocolos de redes e também lidar com a geração de tráfegos de dados em uma rede com suas distribuições estatísticas. Possui suporte para simular eventos como consumo de energia gerada pelos nós sensores e respectiva conectividade entre eles.

- SINALGO: desenvolvido na linguagem de programação Java, esse software de simulação de redes é um dos principais simuladores para redes de sensores sem fio, devido ao seu suporte para criar RSSF com mais de 10 mil nós sensores. 
- OMNet++: ambiente de simulação de eventos discretos com foco na orientação a objetivos. Devido a sua característica de arquitetura modular é possível adicionar a ele novas funções a partir de módulos específicos, como por exemplo, módulos para redes de sensores sem fio (KAMARUDIN, 2010). 


\section{Material e Métodos}

Este capítulo apresenta os métodos e recursos utilizados para a realização do trabalho proposto. Em primeiro momento é descrita a ferramenta que foi utilizada para a realização das simulações e, em seguida, o processo de criação dos cenários que fizeram parte do experimento.

\subsection{Ambiente de simulação}

Para que fosse possível analisar o comportamento dos padrões ZigBee e IEEE 802.11ah em uma RSSF atuando em ambiente externo, determinou-se que o meio mais viável para os experimentos seria a simulação via computador, através de um software específico para essa tarefa.

A escolha pela realização dos testes simulados tem como referência o trabalho apresentado por Balduino e Rocha (2013), em que foram realizados testes comparativos entre meios de comunicação nas RSSF. Coan (2013) que realizou simulações de sistemas distribuídos. Evangelista et al. (2011) que apresentaram um modelo de simulação para troca de mensagens e Jesus e Santos (2013) os quais realizaram testes de redes no sistema operacional Linux OpenSuse de redes no sistema operacional Linux OpenSuse.

A vantagem em utilizar a simulação por software, se deve à capacidade de realizar diversos experimentos sem a necessidade de construir ou implementar um determinado projeto, ou seja, é possível analisar o comportamento de um projeto antes de sua execução.

Por meio da simulação computacional pode-se criar um modelo e um método experimental em que seja possível prever o comportamento do modelo, além de permitir modificações nas variáveis dimensionadas e promover a construção de teorias e resultados a partir da análise dos dados.

Para a realização dos testes, foi utilizado o software OMNet++ 4.5, juntamente com uma ferramenta de extensão chamada Mixim. A escolha desse software se embasou nas pesquisas realizadas por Evangelista et al. (2011) e Jesus e Santos (2013), em que os autores simulam eventos de RSSF por intermédio desta ferramenta obtendo êxito nos testes efetuados. 
Coan (2013), afirma que esta ferramenta de simulação de eventos discretos foi elaborada por Andras Vargas, na Technical University of Budapest em 1998, cuja característica de sua criação é funcionar como um framework modular, baseado na linguagem C. Seu propósito é realizar simulações de redes e demais sistemas de propósito universal.

\subsection{Descrição do software utilizado}

O software OMNet++ é um simulador de eventos discretos em que as variáveis utilizadas podem mudar de comportamento em pontos distintos em um determinado intervalo de tempo. Possui uma linguagem de programação própria, chamada Network Description (NED), podendo seus componentes serem programados em linguagem de programação $\mathrm{C}++$. Além disso, quando se cria um novo projeto no OMNet++ é gerado um arquivo chamado por padrão de "omnetpp.ini", que contém configurações do ambiente a ser simulado.

O OMNet++ possui módulos (camadas) que podem ser ajustadas conforme a necessidade do que se deseja simular. Neste trabalho, os módulos da camada física e enlace sofreram alguns ajustes para que fosse possível a realização dos testes com os padrões ZigBee e IEEE 802.11ah.

Em relação a confiabilidade e integridade das mensagens trocadas dentro do ambiente de simulação, mais precisamente entre transmissor e receptor, os módulos simples foram programados com a tarefa de garantir a eficiência no momento da comunicação, verificando o envio, bem como o recebimento por parte do nó (destino).

Existem também módulos compostos que possibilitam realizar simulações com outras tecnologias além das utilizadas nas RSSF. Ambos os módulos contam com algoritmos internos que permitem calcular, medir o tempo e analisar se há existência de pacotes corrompidos, os quais deverão ser reenviados (EVANGELISTA et al., 2011).

O ambiente OMNet++ oferece ao usuário uma área de criação e desenvolvimento do projeto que se pretende testar. Além disso, assim que o projeto é executado, um outro ambiente é aberto para realizar as simulações que foram desenvolvidas. Ao término das simulações é possível salvá-las em um arquivo 
especial, para ser analisada posteriormente, por meio de ferramentas de análise estatística.

A Figura 9 exibe o ambiente de desenvolvimento das simulações, assim como os demais componentes para configurações do modelo proposto para o teste.

Figura 9 - Ambiente de desenvolvimento do OMNet++

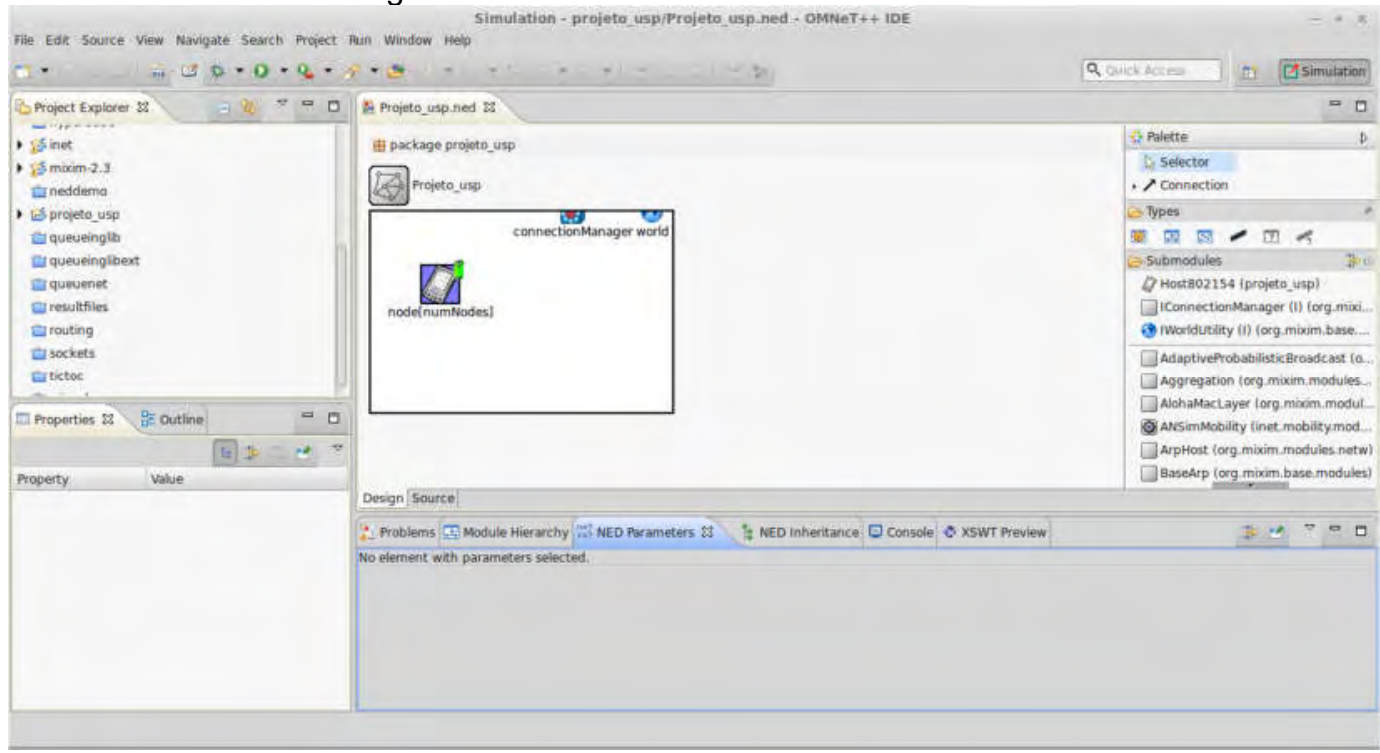

Fonte: Própria autoria.

A Figura 10, exibe uma janela que contém a simulação sendo executada em tempo real.

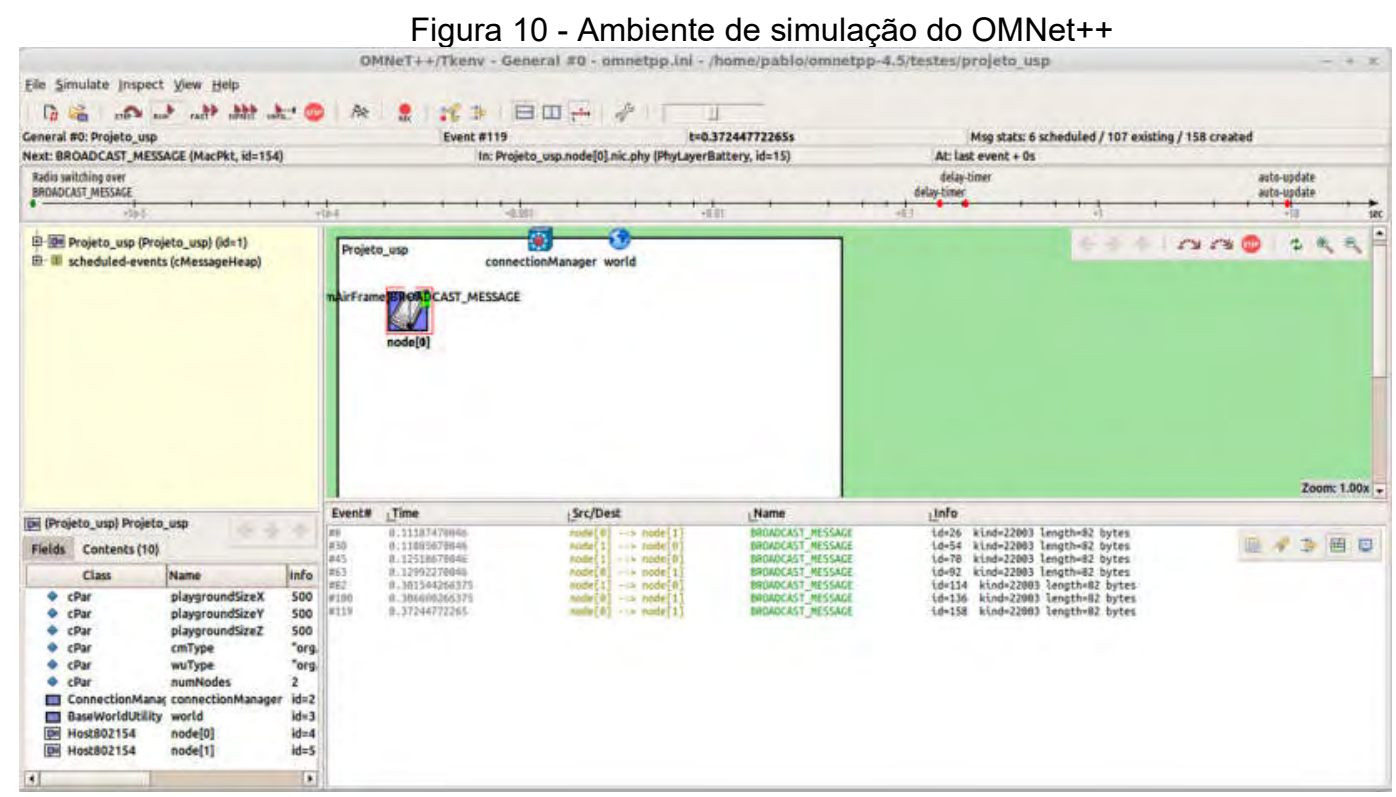

Fonte: Própria autoria. 
Outra vantagem da utilização desta ferramenta está no fato de que, durante o processo de criação, execução e análise de resultados o usuário tem como preocupação o projeto em si, não havendo necessidade de programar elementos internos, que são responsáveis pela simulação (COAN, 2013).

Entre os projetos desenvolvidos, os principais são o Castalia e o MiXim, ambos específicos para realizações de simulações de redes de sensores sem fio. Este último em especifico foi o escolhido para a realização das simulações.

\subsubsection{Framework Mixim}

Trata-se de um conjunto de ferramentas específicas para a realização de simulações de redes de sensores sem fios (redes wireless), redes móveis, entre outras.

Este conjunto de software é configurado dentro do próprio ambiente OMNet++ e já vem com parâmetros pré-definidos para auxiliar nos testes de simulações.

A própria equipe de desenvolvedores do OMNet++ mantém atualizado essa framework, afim de manter alinhado a referida tecnologia, com as mais recentes tecnologias criadas de framewoks.

\subsection{Características do ambiente de simulação}

Para atingir os objetivos específicos propostos neste trabalho, primeiramente foi realizado um levantamento das informações necessárias para criação dos cenários dentro do software. Foram criados dois projetos em paralelo, um para cada tecnologia de transmissão de dados apresentada. Para cada projeto criado houve a necessidade de configurar o arquivo "omnetpp.ini”, para atender aos requisitos apresentados.

Os seguintes parâmetros e valores foram considerados para a realização dos experimentos:

- Área de cobertura: os cenários desenvolvidos para as simulações se basearam nas limitações tecnológicas dos sensores que constituem uma RSSF. E, de acordo com os resultados obtidos durante as simulações, determinou-se que a última área simulada teria um raio de alcance de 1500 metros ou 706,85 hectares, entre o ponto transmissor (NR) e receptor dos dados (NC), conforme Figura 11. 
Entretanto, os padrões testados não obtiveram resultados satisfatórios nessa distância, o mesmo foi utilizado apenas como referência.

Figura 11 - Área de cobertura da RSSF simulada

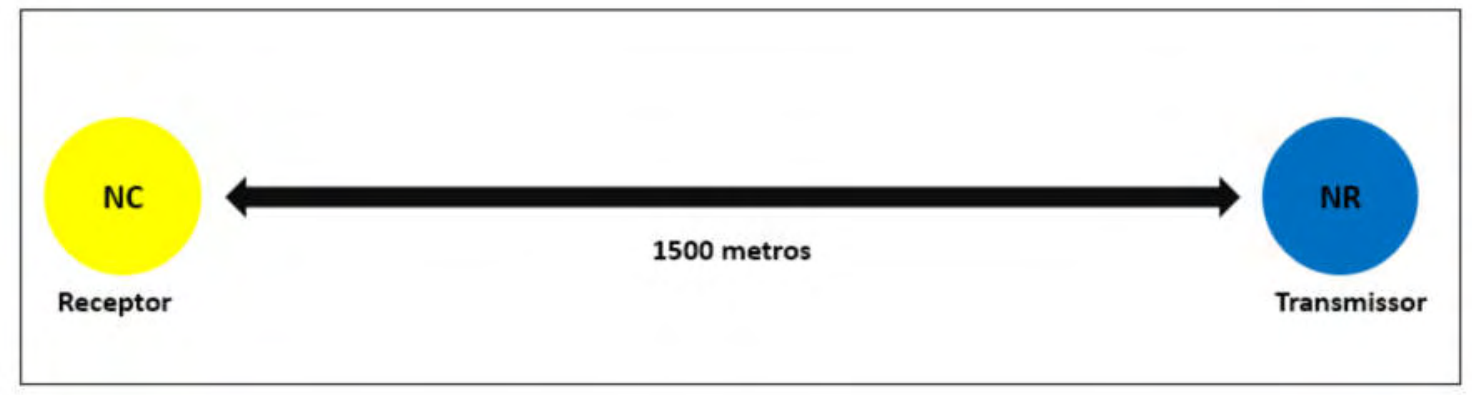

Fonte: Própria autoria.

Em relação ao posicionamento dos nós, estes foram alinhados horizontalmente, um em relação ao outro.

- Topologia da Rede de Sensores Sem Fio: os testes foram realizados com base em uma RSSF hierárquica, conforme apresentada no subcapítulo 3.1.3. Em relação à topologia utilizada, estabeleceu-se que a estrutura em malha apresentou melhores resultados, em relação a medição do alcance de sinal, pelo fato de haver um único ponto receptor (Estação Base) dos dados transmitidos pelos nós sensores. Através da figura 11 percebe-se que o nó coordenador é o nó líder, que receberá os dados dos nós sensores que constituem a RSSF.

- Nós utilizados: foram utilizados nos experimentos um nó coordenador e um nó roteador. Devido à característica da RSSF simulada, os nós sensores comuns não estiveram presentes nas medições, pelo fato de que a presença deles não iria interferir nos resultados, já que o propósito desta pesquisa é medir o sinal de comunicação entre NC e NR.

- Elementos utilizados para as simulações: devido ao fato que uma RSSF pode ser composta por diversos nós, foi preciso estipular a quantidade de dados que NC transmitiria ao NR, para servir como parâmetro nas simulações. O volume de dados transmitidos pelo NC até o NR representou as informações coletadas dos NSC, desta forma, determinou-se que seriam transmitidos 50 pacotes de 100 bytes cada, representando neste caso informações coletadas de cinquenta NSC. 
- Características do cenário: todos os experimentos se basearam em uma RSSF atuando em ambiente externo, simulando um campo ou uma fazenda. As medições do alcance de sinal foram realizadas em um ambiente considerado ideal, ou seja, ausente de complicações ou imprevistos. A escolha em realizar os testes nesse tipo de característica de cenário deve-se ao objetivo proposto neste trabalho.

\subsection{Procedimentos para medição do sinal}

Para determinar qual dos padrões estudados apresentam melhor desempenho, quando se leva em considerando a distância entre dois pontos de comunicação em uma RSSF, com aplicação em ambiente aberto, como uma fazenda foi necessário analisar as métricas que seriam utilizadas para comporem os experimentos.

Com base nos trabalhos de Souza et al. (2013), Garay e Kofuji (2008) e no documento técnico Request for Comments RFC-2544, o qual apresenta detalhes técnicos dos protocolos de comunicação de dados, sendo mantido e controlado pelo Internet Engineering Task Force (IETF²), as seguintes métricas são aplicadas para analisar o alcance de um sinal eletromagnético:

- Taxa de Perda de Pacotes (TPP): pacotes de dados perdidos durante a transmissão. O cálculo se obtém através do total de pacotes enviados com sucesso, menos o número de pacotes com erros;

- Latência: tempo medido em milissegundos para que uma mensagem completa seja entregue ao receptor;

- Intensidade de Sinal: potência de um sinal recebido, sendo a unidade de medida o Decibel-miliwatt (dBm); e

- Perda no espaço livre: quantidade de força de sinal eletromagnético que é perdido (medido em decibel - $\mathrm{dB}$ ) entre duas antenas.

Para este trabalho foram escolhidas as métricas latência e TPP para analisar o desempenho das tecnologias de comunicação ZigBee e 802.11ah com relação ao alcance do sinal de transmissão de dados (distância) entre o nó coordenador e o nó roteador. As demais grandezas físicas como potência, intensidade de sinal e perda

${ }^{2}$ IETF: instituição sem fins lucrativos, responsável por fornecer normas e especificações técnicas sobre o funcionamento dos protocolos de comunicação em uso nas redes de computadores (FOUROUZAN, 2008). 
no espaço livre de sinal, não fizeram parte das simulações, pelo fato de que estas apresentam melhor comportamento em uma RSSF implantada e não simulada.

Para se calcular a taxa de pacotes perdidos, faz-se o uso da seguinte eq.(1):

TPP $=$ Total de Pacotes Transmitidos Total de Pacotes Recebidos com Sucesso

A diferença entre a quantidade de pacotes transmitidos e recebidos com sucesso deve ser transformada em percentual. Considera-se pacote perdido, todo e qualquer pacote que durante o envio de seu conteúdo foi corrompido ou danificado por fatores como ruídos eletromagnéticos, condições climáticas, falha do dispositivo ao despachar e anomalia do meio físico (TANENBAUM, 2011)

De acordo com Forouzan (2008), latência é o tempo em que uma mensagem completa é recebida com sucesso pelo nó destino. Compreende-se por mensagem completa um conjunto de pacotes transmitidos pela RSSF. O cálculo para determinar a latência entre dois pontos é constituído por quatro fatores, de acordo com a eq.(2):

Latência $=$ Tempo de Propagação + Tempo de Transmissão + Tempo de Fila + Retardo de Processamento

Onde:

- Tempo de propagação: constituído através da distância física entre os pontos comunicadores e a velocidade de transmissão, como representado na eq.(3):

Tempo de Propagação $=\frac{\text { Distância }}{\text { Velocidade de Propagação }}$

- Tempo de transmissão: para se obter o tempo de transmissão é preciso levar em consideração o tamanho da mensagem enviada e a largura de banda do canal de transmissão. A equação para determinar esse tempo é pela eq.(4):

Tempo de Transmissão $=\frac{\text { Tamanho da mensagem }}{\text { Largura de banda do canal }}$

- Tempo de fila: antes de uma mensagem ser processada pelo receptor, esta fica armazenada durante um determinado período, ou seja, conforme os 
pacotes chegam ao receptor, estes são mantidos em memória para serem processados em fila, um por um. Em uma RSSF esse tempo pode variar muito, pois depende da quantidade de nós roteadores no ambiente, da distância entre eles e o nó coordenador, bem como da quantidade de mensagens.

- Retardo de processamento: tempo para analisar o pacote de dados recebido, checar seu conteúdo, remover dados que não serão processados e processar o conteúdo válido.

Como pode ser observado, para obter o valor da métrica Latência é preciso analisar diversas variáveis como quantidade de dados transmitidos, tamanho dos dados a serem transmitidos, capacidade de processamento dos nós, condições ambientais, dentre outros fatores. Para medir a latência, levou-se em consideração o tamanho e a quantidade dos bytes transmitidos entre NC e NR. Demais variáveis não foram incluídas nos testes devido às limitações do software para esse tipo de medição.

Reforçando que o NR acumula uma determinada quantidade de informações obtidas dos NSC e despacha para o NC, sendo que a quantidade de informações que ele armazena antes de transmitir pode variar de acordo com o fabricante do dispositivo e dos componentes internos.

O preenchimento dos campos internos (cabeçalhos) dos pacotes de dados que fazem parte tanto do ZigBee quanto do IEEE 802.11ah, são administrados pelo software OMNet++ e para as simulações pretendidas não foi necessário intervir nesse procedimento, já que o conteúdo dos campos não teria influência sobre o projeto abordado.

Em relação aos dados transmitidos para testes, o preenchimento dos pacotes (payload) conteve apenas dados do tipo texto, somente para atingir o tamanho pretendido.

Segundo a documentação RFC 2544 emitida pelo Institute of Engineering Task Force (IETF), juntamente com a recomendação G. 114 fornecida pelo comitê gestor de telecomunicações International Standardization Union (ITU-T, 2003), o nível aceitável para a Taxa de Perda de Pacote é de 10\% e o Atraso Médio (AM) tolerável deve ser inferior a 450 ms tanto para o padrão ZigBee quanto para o IEEE 802.11ah. 
Importante salientar que são recomendações e não obrigatoriedade os valores propostos pelos órgãos citados. Isto porque, dependendo dos recursos e finalidades de uma RSSF, esses valores podem sofrer alterações, podendo ou não serem aceitos pelo projetista que está implantando a tecnologia e seu cliente, neste caso o proprietário rural.

Para obter maior exatidão nos testes, foi necessário utilizar-se de métodos estatísticos como: média, coeficiente de determinação $\left(R^{2}\right)$ e probabilidade de significância (valor-p) aplicado nas métricas utilizadas nos ambientes de simulação. Através software Microsoft Excel 2013 foram gerados os cálculos necessários para obter os dados estatísticos e os gráficos; dentre os quais foram discutidos no capítulo 5 deste trabalho.

\subsection{Síntese dos parâmetros utilizados}

A tabela 5 exibe os parâmetros que foram utilizados para as simulações executadas no software OMNet++.

Tabela 5 - Definições dos módulos a serem simulados

(continua)

\begin{tabular}{lll}
\hline Definições & $\begin{array}{l}\text { ZigBee (Módulo Xbee- } \\
\text { Pro (Série 2) }\end{array}$ & $\mathbf{8 0 2 . 1 1 a h ~}$ \\
\hline Padrão & 802.15 .14 & $802.11 \mathrm{ah}$ \\
Frequência & $900 \mathrm{MHz}$ & $900 \mathrm{MHz}$ \\
Tamanho máximo da área & 1500 metros & 1500 metros \\
Topologia da RSSF & Hierárquico & Hierárquico \\
Posição dos nós & Estática & Estática \\
Modo de atividade (Nós) & Reativo & Reativo \\
Protocolo de comunicação & LEACH & LEACH \\
Métricas utilizadas & TPP, Latência & TPP, Latência \\
Nós utilizados & NC / NR & NC / NR
\end{tabular}


Tabela 5 - Definições dos módulos a serem simulados

(conclusão)

\begin{tabular}{lll}
\hline Definições & $\begin{array}{l}\text { ZigBee (Módulo Xbee- } \\
\text { Pro (Série 2) }\end{array}$ & $\mathbf{8 0 2 . 1 1 a h ~}$ \\
\hline Tamanho dos pacotes & 100 Bytes & 100 Bytes \\
Tamanho das mensagens & 1000 Bytes & 1000 Bytes \\
Taxa de transferência & 250 Kbps & 150 Kbps \\
Tensão de alimentação & $3.6 \mathrm{~V}$ & $3.6 \mathrm{~V}$ \\
Antena & Chip integrado & Chip integrado \\
\hline
\end{tabular}

Fonte: Própria autoria.

Em virtude da complexidade em simular todos os eventos possíveis para medição de sinal dentro de uma RSSF atuando em campo aberto, alguns elementos não estiveram presentes nos testes, como: condições climáticas, relevos, obstáculos, ruídos eletromagnéticos e níveis de potência das antenas transmissoras.

\subsection{Etapas das simulações}

Os testes foram realizados de acordo com a distância entre NR (Transmissor) e o NC (Receptor). Inicialmente estipulou-se que a distância máxima fosse de 1000 metros, porém devido as baixas variações dos dados medidos durante os testes iniciais, determinou-se que a distância máxima seria de 1500 metros, realizando as medições em intervalosde 100 em 100 metros entre NR e NC.

Para cada métrica avaliada, foram realizadas 10 medições com intervalos de 10 segundos entre elas, sendo que para cada distância de 100 metros entre NR e NC, repetiu-se o mesmo procedimento até a distância máxima obtida pelas tecnologias. Ao final dos testes foi criada uma média entre as 10 medições para cada faixa de distância e com o valor disponível foi possível efetuar as análises. A Figura 12 demonstra como os testes procederam. 
Figura 12 - Posição dos Nós para medição

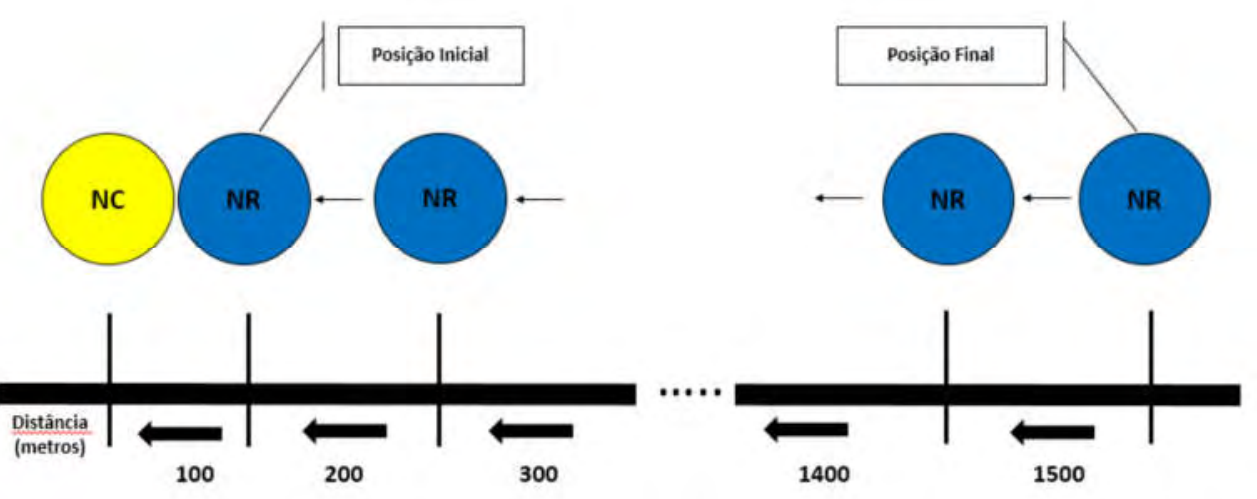

Fonte: Própria autoria.

Uma vez definido a maneira como as simulações seriam executadas, criou-se no software OMNet++ um novo projeto intitulado RSSF_ZigBee_802, contendo arquivos e configurações condizentes aos experimentos desejados. Dentre os diversos arquivos do projeto, alguns destes, como por exemplo, omnetpp.ini, wsnrouting.ned, flooding-X.sca sofreram ajustes de alguns parâmetros apresentados na tabela 5 para se adequar ao propósito deste trabalho.

Após as configurações realizadas no ambiente OMNet++, conforme exibido pelas Figuras 13 e 14, respectivamente, deu-se início as fases dos testes. Observase que na Figura 13 é apresentada a área de desenvolvimento, onde foram inseridos os componentes que fizeram parte das simulações. Após efetuar a inserção destes, um arquivo chamado wsnrouting.ned foi gerado dentro do projeto. 
Figura 13 - Área de inserção dos componentes

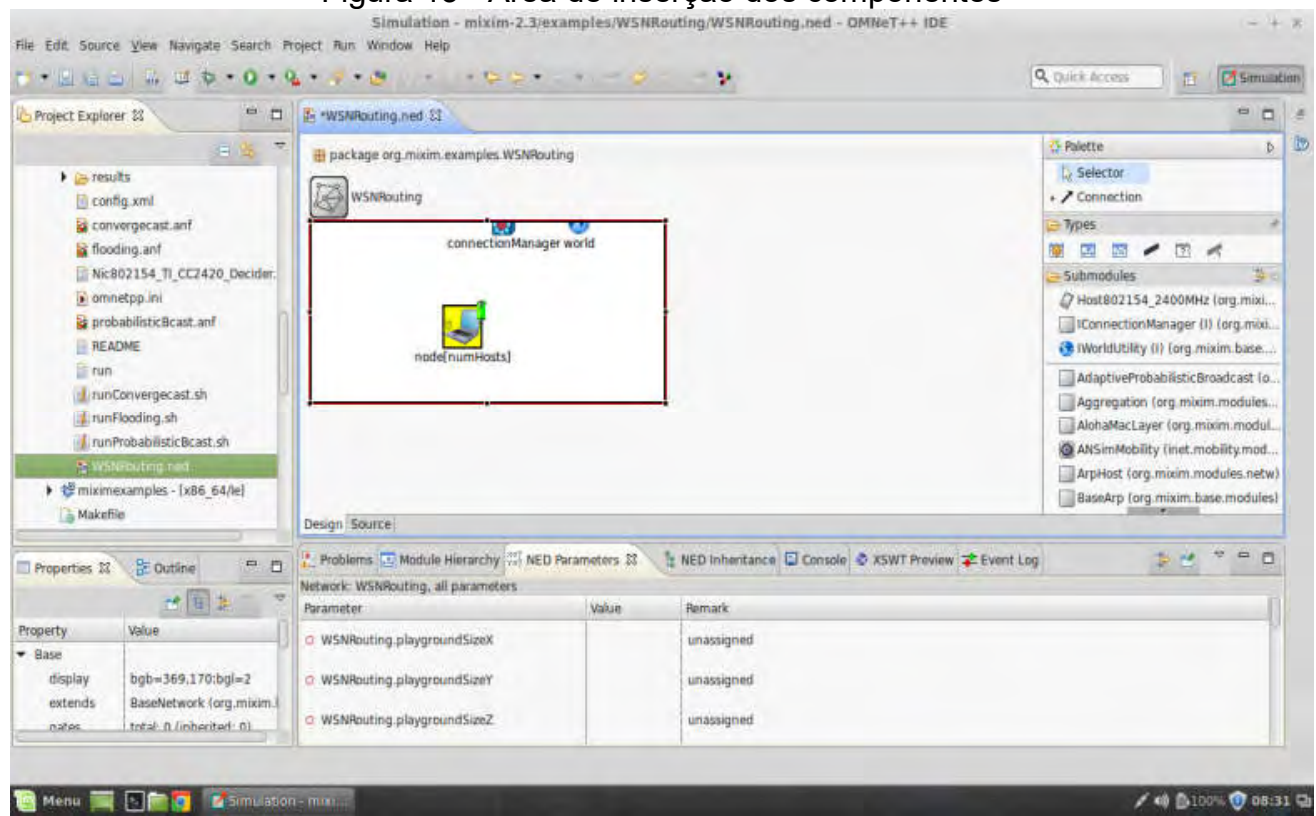

Fonte: Própria autoria.

Figura 14 - Ambiente de programação da simulação

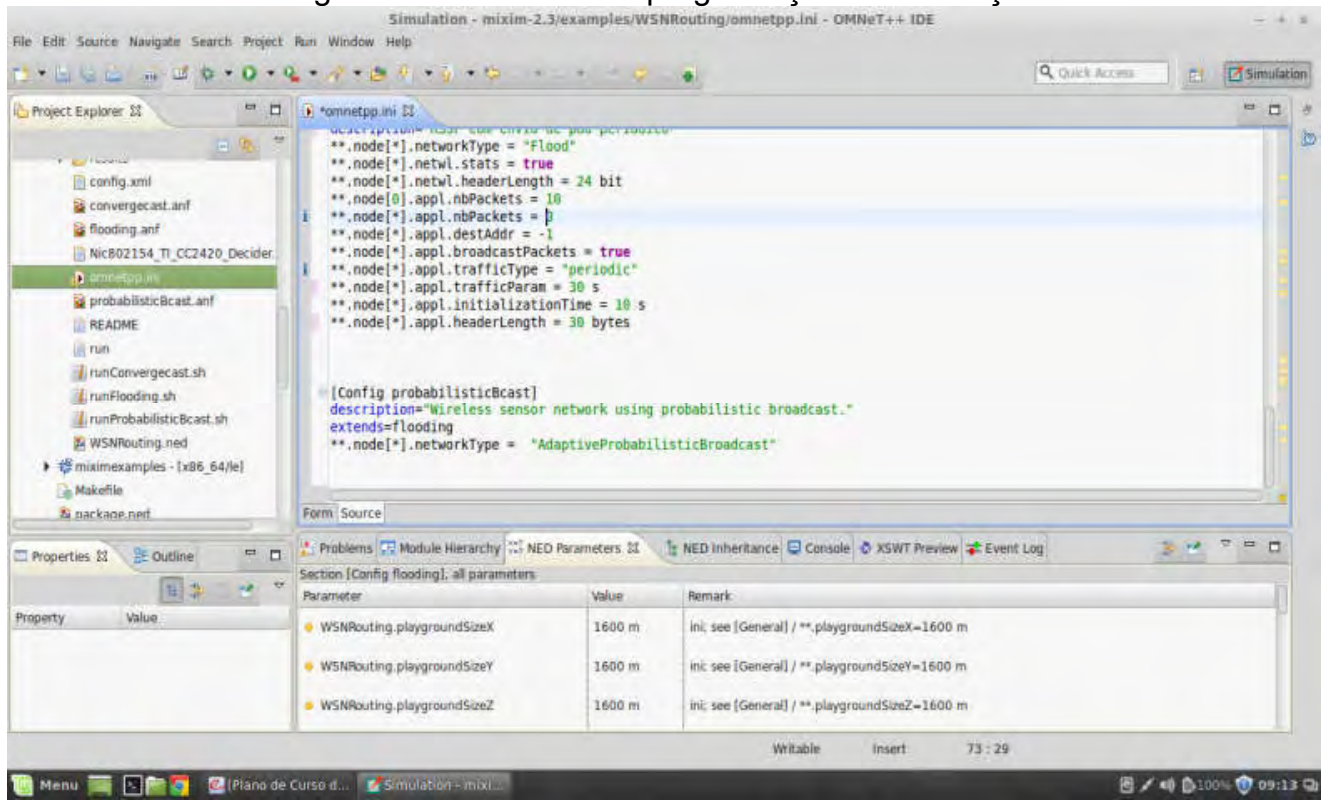

Fonte: Própria autoria.

Após realizadas todas as simulações pretendidas, os dados foram tratados e preparados para a análise e construção de gráficos e tabelas, que serão apresentados e comentados no próximo capítulo. 


\section{Resultados e Discussões}

Serão apresentados e discutidos neste capítulo as análises dos resultados, referentes às simulações realizadas com os dois padrões de transmissão de dados, atuando em longa distância em uma RSSF. Como mencionado no capítulo 4, as métricas utilizadas foram: TPP, latência e distância.

Em todas as simulações realizadas a métrica distância foi determinante, pois como o objetivo era medir o desempenho das tecnologias diante da distância física entre seus dispositivos, foi necessário relacioná-la às demais variáveis, comentadas anteriormente.

Com a finalidade de obter resultados mais precisos e condizentes, foram realizadas 600 (seiscentas) simulações no total. Como descrito no capítulo 4, os testes ocorreram de acordo com o aumento da distância física entre NR e NC, sendo que para cada 100 metros uma nova simulação era realizada.

Para cada padrão de comunicação deste trabalho foram realizadas 300 (trezentas) simulações, sendo 150 (cento e cinquenta) para medir a TPP e 150 (cento e cinquenta) para medição da latência. Gradativamente a cada 100 metros, realizou-se 10 simulações tanto para o protocolo ZigBee quanto para o IEEE .11ah. Ao final dos testes os dados foram condensados em uma planilha onde foram calculadas as médias dos dados coletados.

Dentre as três medidas utilizadas para analisar os dados ficou determinado, como descrito por Banks et al. (2009), Kamarudin et al. (2010) e Verona (2010), que os valores obtidos a partir da média foram adequados para analisar e validar as duas tecnologias testadas por meio das métricas empregadas.

Após os procedimentos feitos na área de desenvolvimento do software OMNet++ 4.5, para que fosse possível a realização das simulações, o software fornece ao usuário uma área especifica para executar a simulação desejada, conforme a Figura 14, exibida no subcapítulo 4.6.

Para obtenção dos dados de cada resultado dos testes, o software OMNet++ criou um arquivo chamado flooding-0.sca, contendo dados relevantes ao experimento propriamente dito. Entretanto, esses dados precisaram ser tratados para extrair deles somente informações especificas que foram exportadas para uma planilha do Microsoft Excel. 
A Figura 15 apresenta a área do OMNet++, que contém o arquivo de saída e a Figura 16 exibe parte do conteúdo do arquivo examinado.

Figura 15 - Arquivo do resultado das simulações

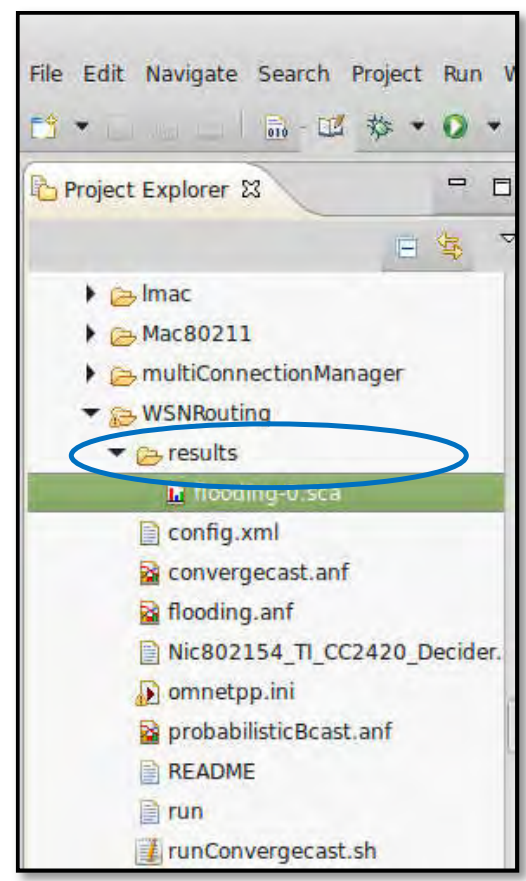

Fonte: Própria autoria.

Figura 16 - Dados relacionados ao arquivo de saída do OMNet++

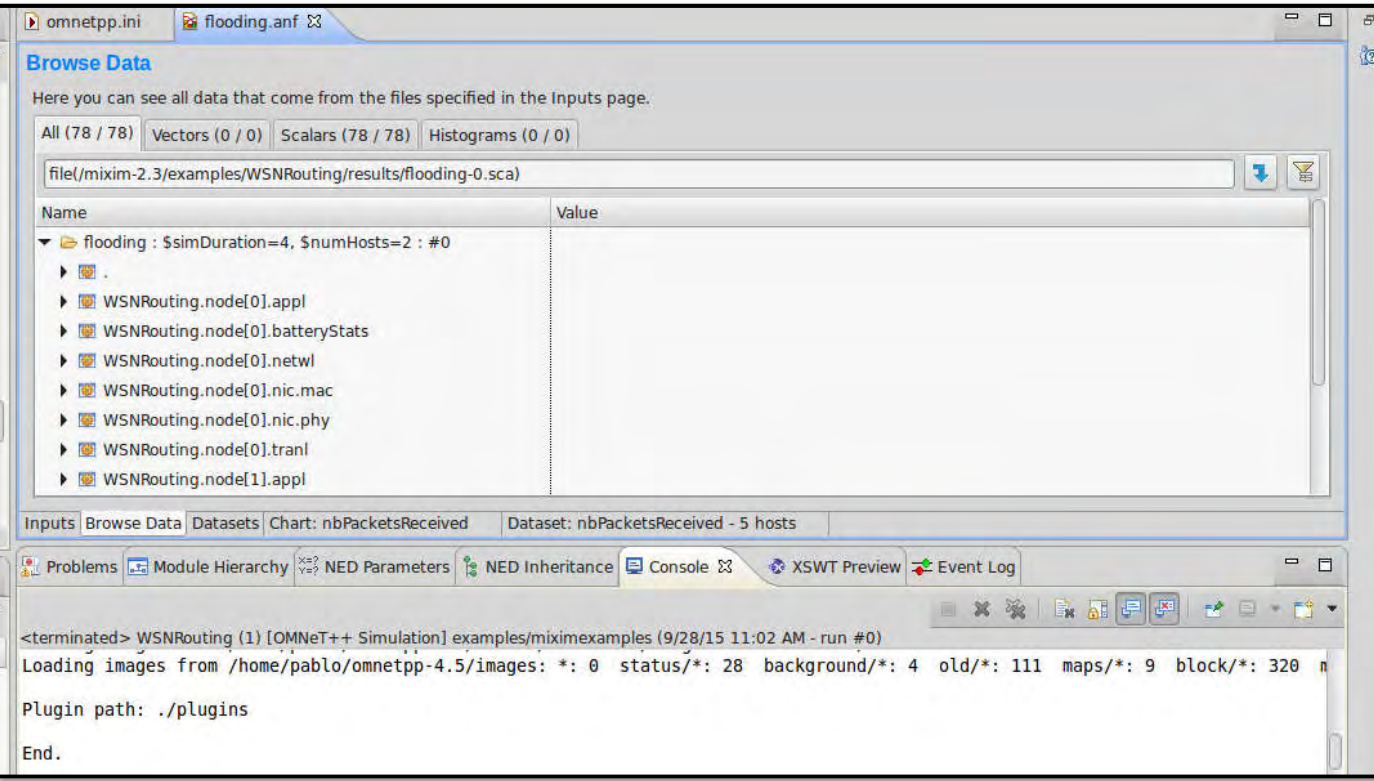

Fonte: Própria autoria. 
Os resultados e discussões das simulações foram organizados do seguinte modo:

- Subcapítulo 5.1 Análise - Taxa de Perda de Pacotes: são discutidos aqui os experimentos realizados com as métricas Distância e TPP, envolvendo os padrões ZigBee e IEEE 802.11ah;

- Subcapítulo 5.2 Análise - Latência: comenta-se aqui os testes efetuados com as métricas Distância e Latência para ambos os padrões;

- Subcapítulo 5.3 Dificuldades encontradas: relato dos principais desafios ocorridos durante as simulações e análise dos resultados.

Ao final de cada subcapítulo (exceto o 5.3) criou-se tópicos para discutir os resultados abrangendo os dois padrões de comunicação.

\subsection{Análise - Taxa de Perda de Pacotes}

Primeiramente foram analisados os resultados obtidos através da simulação fazendo uso da tecnologia ZigBee. Como o objetivo era determinar quais das tecnologias apresentassem a menor TPP em relação ao aumento da distância entre os nós comunicados da RSSF em campo aberto, efetuou-se 10 (dez) testes para cenário e após isso, as informações foram tabuladas.

Para que fosse possível obter a TPP durante a transmissão de dados entre o Nó Roteador e o Coordenador foi necessário registrar os seguintes itens, em uma planilha:

- Distância;

- Quantidade de pacotes transmitidos;

- Quantidade de pacotes recebidos;

- Taxa de pacotes recebidos com sucesso;

- Quantidade de pacotes perdidos;

- Taxa de perda de pacotes.

As métricas utilizadas para análise dos resultados foram: distância determinada em metros e TPP e medida através de porcentagem. Iniciou-se as simulações posicionando os nós comunicadores a uma distância de 100 metros entre eles. A 
cada dez segundos foram realizadas novas simulações, dentro da distância estabelecida, totalizando dez simulações por fase.

Para cada posicionamento do NR em relação ao NC, o software OMNet++ gerou-se um arquivo chamado flooding-0.sca, do qual foram extraídos os resultados das simulações e inseridos em uma planilha eletrônica.

Entretanto, as informações disponibilizadas por esse arquivo precisaram ser organizadas, para facilitar a leitura. Dessa forma, foi preciso editar o arquivo para que na sequência os dados fossem coletados e armazenados.

O programa Microsoft Excel 2013 foi utilizado para esse fim, no qual foram anotados os seguintes dados: quantidade de pacotes perdidos, taxa de pacotes recebidos com sucesso, quantidade de pacotes perdido e taxa de perda de pacotes. Todos os resultados dos testes se encontram no APÊNDICE A e B.

Para se obter a taxa de pacotes perdidos, durante a transmissão dos dados, a eq.(5) foi utilizada:

$$
T P P=(P P \div P T) \times 100
$$

Onde:

$T P P=$ Taxa de Perda de Pacotes;

$P P=$ Quantidade de Pacotes Perdidos;

$P T=$ Quantidade de Pacotes Transmitidos;

Ao final das simulações foi elaborada uma tabela com a média de TPP, para cada distância, conforme apresentado na Tabela 6 a seguir:

Tabela 6 - Média da Taxa de Perda de Pacotes

\begin{tabular}{ccc}
\hline Distancia (metros) & Média TPP - ZigBee & Média - TPP 802.11ah \\
\hline 100 & $0,12 \%$ & $0,16 \%$ \\
200 & $0,51 \%$ & $0,18 \%$ \\
300 & $0,97 \%$ & $0,56 \%$ \\
400 & $1,53 \%$ & $1,02 \%$ \\
500 & $3,10 \%$ & $1,52 \%$ \\
600 & $3,16 \%$ & $2,39 \%$ \\
700 & $3,60 \%$ & $4,33 \%$ \\
800 & $5,60 \%$ & $6,60 \%$
\end{tabular}


Tabela 6 - Média da Taxa de Perda de Pacotes (conclusão)

\begin{tabular}{ccc}
\hline Distancia (metros) & Média TPP - ZigBee & Média - TPP 802.11ah \\
\hline 900 & $7,10 \%$ & $8,46 \%$ \\
1000 & $7,31 \%$ & $9,94 \%$ \\
1100 & $8,66 \%$ & $14,51 \%$ \\
1200 & $8,73 \%$ & $16,62 \%$ \\
1300 & $9,95 \%$ & $35,54 \%$ \\
1400 & $12,09 \%$ & $100 \%$ \\
1500 & $14,38 \%$ & $100 \%$ \\
\hline
\end{tabular}

Fonte: Própria autoria.

Por meio das informações da Tabela 6, fez-se a análise dos resultados apresentados por cada padrão de comunicação. Além disso, foram gerados os gráficos e as regressões lineares.

Os testes se iniciaram com o padrão ZigBee, onde foram realizadas 10 (dez) simulações de transmissão de dados para cada distância de 100 metros. O valor de cada teste foi anotado e ao final dos 10 testes, efetuou-se a média aritmética. Após os eventos, os valores da média da TPP de cada distância simulada foram representados por meio de um gráfico, conforme apresentado na Figura 17.

Figura 17 - Taxa de Perda de Pacotes do padrão ZigBee

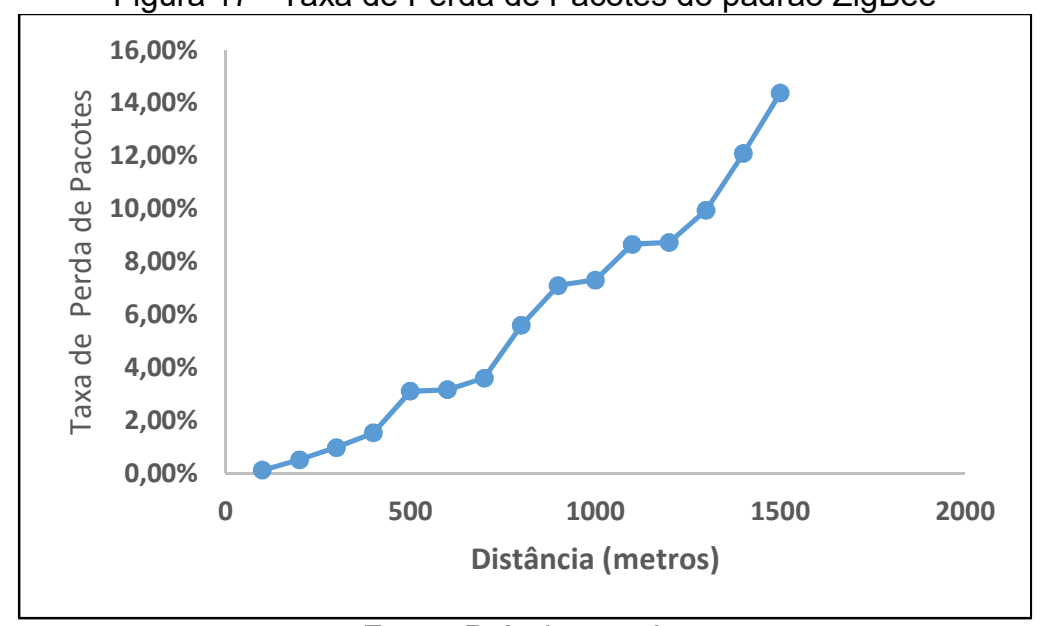

Fonte: Própria autoria.

Constatou-se que a TPP segue uma linha crescente conforme aumenta-se a distância entre os nós comunicadores, sendo que a porcentagem de perda de pacotes se mantém dentro dos $10 \%$, até a distância de 1100 metros entre transmissor e receptor. 
De acordo com as normas do IETF e o estabelecido para esta pesquisa, o valor aceitável da TPP não deve ultrapassar os $10 \%$, mas mesmo atingindo os $14,38 \%$ de perda, ainda é possível operar com essa tecnologia numa RSSF em área externa.

Após a análise e discussão dos testes com o padrão ZigBee, repetiu-se os mesmos procedimentos com o padrão IEEE 802.11ah, alterando alguns parâmetros para atender ao padrão, conforme a Tabela 4 do subcapítulo 3.5. Ao término dos testes e a partir da média aritmética dos valores simulados foi criado um gráfico para facilitar a análise dos resultados, conforme é apresentado na Figura 18:

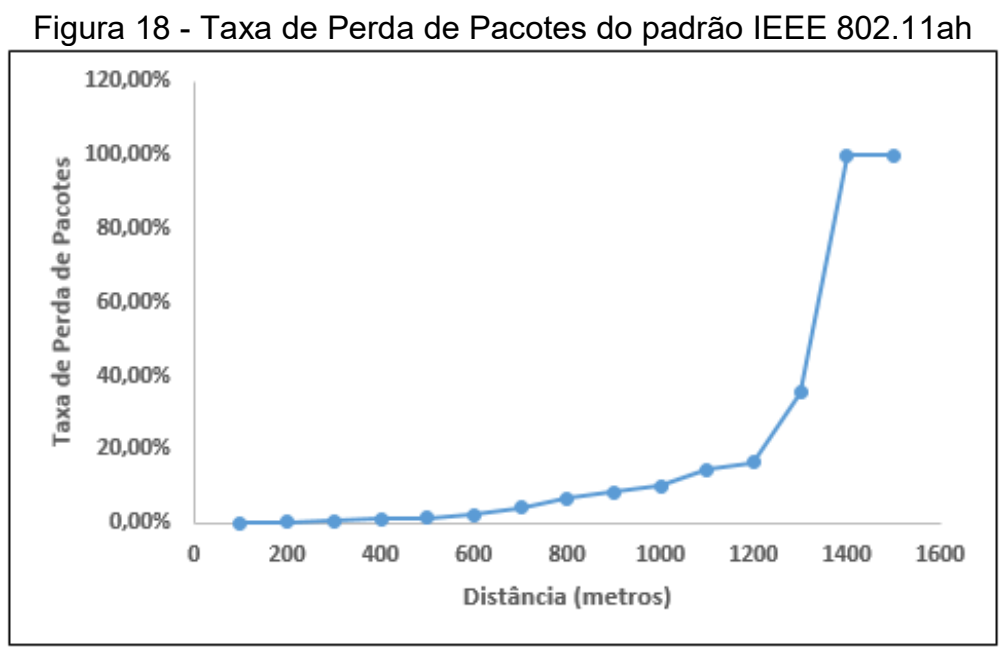

Fonte: Própria autoria.

Pela leitura do gráfico apresentado na Figura 18, a TPP da tecnologia 802.11ah manteve-se estável durante as simulações até atingir a distância de 1100 metros, momento em que ocorreu perdas acima de 14,51\%. Já nas distâncias de 1200 e 1300 metros, as perdas de pacotes foram de 16,62\% e 35,54\%, respectivamente. Acima de 1300 metros, a TPP obteve valores de 100\%, ou seja, todos os pacotes enviados foram perdidos, sendo assim, não foi possível que ambos os nós continuassem a se comunicar. 


\subsubsection{TPP - Comparativo entre os padrões de transmissão}

Após os resultados e discussões sobre cada padrão de transmissão foi realizada uma comparação através do gráfico exibido na Figura 19.

Figura 19 - Comparativo da TPP: ZigBee e IEEE 802.11ah

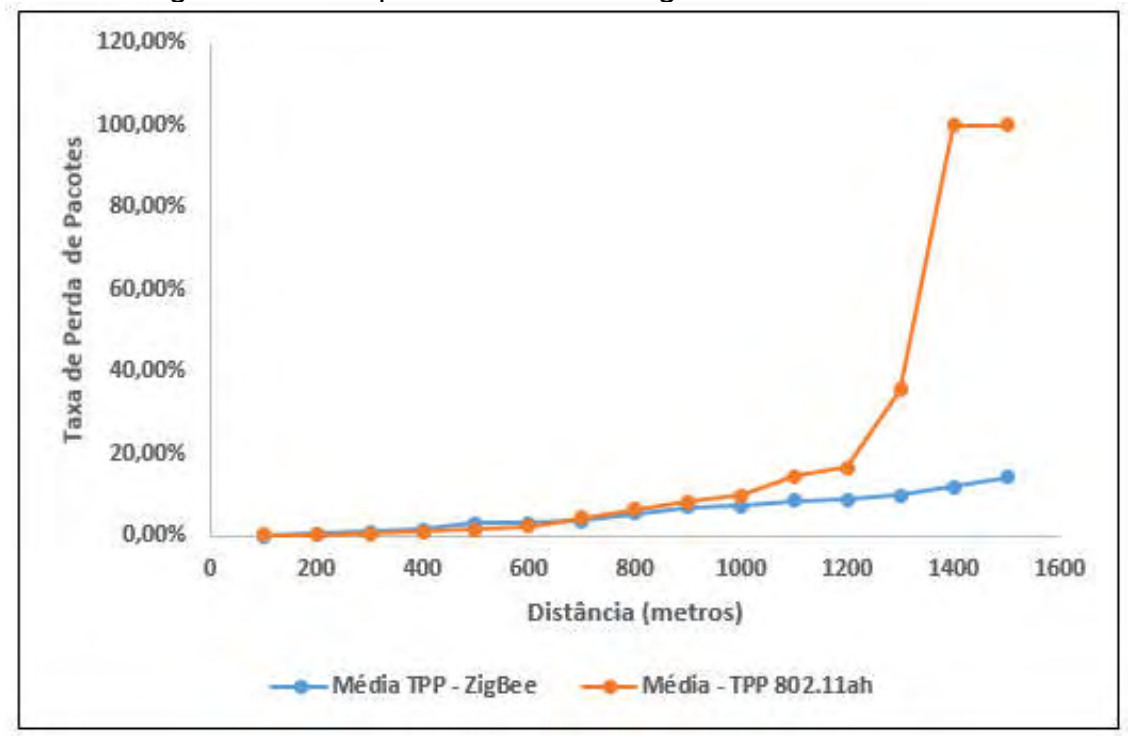

Fonte: Própria autoria.

Ao analisar o desempenho da taxa de perda de pacotes dos padrões ZigBee e IEEE 802.11ah, constatou-se que ambos mantiveram uma baixa perda até a distância de 1000 metros, momento em que o ZigBee atingiu 7,31\% do total de pacotes enviados com sucesso e o IEEE 802.11ah obteve 9,94\%, ou seja, de um total de 1000 pacotes transmitidos, 926,9 foram entregues com sucesso pela tecnologia ZigBee e 900,6 pelo IEEE 802.11ah.

Constata-se que o padrão ZigBee se manteve estável até 1000 metros, já o IEEE 802.11ah mostrou-se ineficiente após 1300 metros de distância, entre o nó roteador transmissor e o nó coordenador receptor.

Conforme apresentado no gráfico comparativo da Figura 19, a tecnologia ZigBee apresentou uma Taxa de Perda de Pacotes mais estável, em relação ao IEEE 802.11ah, nas distâncias simuladas.

Pode-se notar que após 1100 metros, a diferença entre ambas começa a se destacar e ao atingir 1400 e 1500 metros, o padrão IEEE 802.11ah sofre uma perda 
de $100 \%$ dos dados transmitidos. Já o ZigBee apresenta uma perda de 12,09\% e 14,38\% nas mesmas distâncias.

Por meio da regressão linear gerada a partir da distância e TPP, a tecnologia ZigBee apresentou um aumento de perda de pacotes de 0,00009 a cada aumento de 100 metros na transmissão de dados.

Conforme a análise estatística realizada, o nível de significância do valor-p foi menor que 0,05 , e o $\mathrm{R}^{2}$ ajustado em $96,50 \%$, assim sendo, a qualidade de ajuste da regressão foi alta e apresentou a menor oscilação de perda de pacotes entre as distâncias medidas.

Com relação ao padrão IEEE 802.11ah, houve um aumento de perda de pacotes para cada aumento de 100 metros na transmissão de dados, sendo que o nível de significância do valor-p foi menor que 0,05 e $\circ R^{2}$ ajustado em 53,64\%. Houve menor confiabilidade na regressão e ocorreu maior oscilação de perda entre as distâncias medidas com relação ao ZigBee. Os Apêndices $C$ e D contém as regressões lineares de cada tecnologia.

Como apresentado na Tabela 6 deste capítulo, pode-se visualizar a média dos valores da TPP para as duas tecnologias. Com relação à métrica TPP após a análise dos resultados, conclui-se que o padrão ZigBee oferece um desempenho superior ao IEEE 802.11ah com relação a distância e a taxa de perda de pacotes, podendo manter comunicação entre os dispositivos com uma TPP menor que $10 \%$ até 1300 metros, entre os nós transmissores e receptores.

\subsection{Análise - Latência}

As simulações ocorridas para a análise da latência foram realizadas obedecendo-se os mesmos procedimentos adotados nos testes com a taxa de perda de pacotes, ou seja, em primeiro momento fez-se os experimentos com o padrão ZigBee e na sequência com o IEEE 802.11ah.

Pelo fato de que a latência corresponde ao atraso médio em que um pacote de dados leva para ser transmitido até um receptor, essa métrica é influenciada por quatro elementos principais, os quais foram comentados no subcapítulo 4.4. O próprio software de simulação, neste caso o OMNet++ possui em seu mecanismo de funcionamento procedimentos para realizar a simulação a mais próxima possível da 
realidade. Para tanto, faz-se uso de equações e algoritmos previamente programados.

Para se chegar a um valor médio da latência foi preciso levar em consideração a eq.(3), discutido no subcapítulo 4.4 .

Repetindo o mesmo procedimento adotado na simulação com a TPP, o arquivo de resultado chamado isiofifini precisou ser analisado e editado para extrair as informações necessárias para a análise. Os dados foram tabulados em uma planilha e os seguintes itens foram coletados: distância e latência.

Após a inserção dos resultados em uma planilha realizou-se o cálculo da média dos segmentos simulados. A Tabela 7 exibe os resultados que permitiram gerar os gráficos e elaborar a regressão linear de cada tecnologia proposta a partir da média obtida. Os resultados de todos os testes encontram-se disponíveis nos Apêndices $E$ e F.

Tabela 7- Média da Latência do padrão ZigBee e IEEE 802.11ah

\begin{tabular}{ccc}
\hline Distância (metros) & Latência - ZigBee $(\mathbf{m s})$ & Latência 802.11ah (ms) \\
\hline 100 & 142,9 & 239 \\
200 & 143,1 & 241,3 \\
300 & 165,3 & 248,8 \\
400 & 172,2 & 265,2 \\
500 & 174,2 & 265,7 \\
600 & 179,1 & 280,7 \\
700 & 185,9 & 285,6 \\
800 & 186,6 & 303,4 \\
900 & 196,2 & 360,3 \\
1000 & 201,8 & 368,3 \\
1100 & 211,2 & 469,8 \\
1200 & 214,3 & 880,4 \\
1300 & 231,6 & 1059,5 \\
1400 & 254,1 & 1100,8 \\
1500 & 286,3 & 1192 \\
\hline
\end{tabular}

Fonte: Própria autoria.

A partir da média obtida foi gerado o gráfico para o padrão ZigBee, conforme exibe a Figura 20. O eixo $X$ do gráfico informa a distância em metros e o eixo $Y$ apresenta os valores do tempo médio da latência em milissegundos (ms). 
Figura 20 - Latência do padrão ZigBee

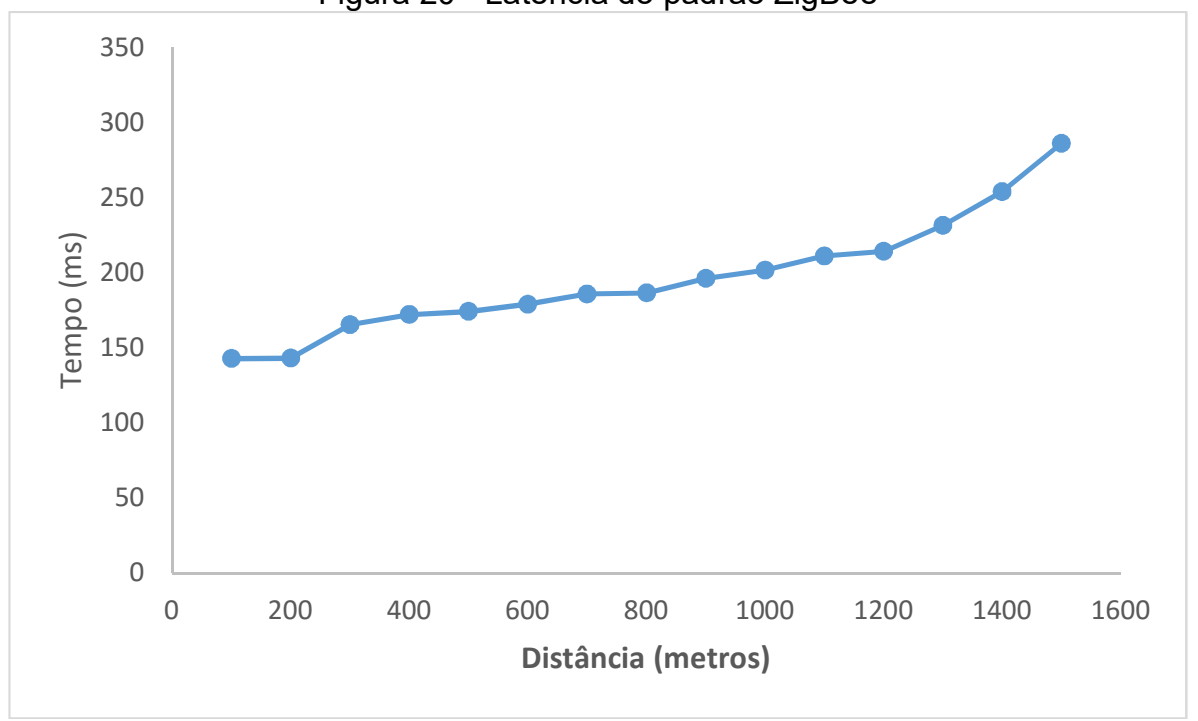

Fonte: Autoria própria.

Analisando o gráfico do padrão ZigBee verificou-se que no início da transmissão dos dados, o tempo médio do envio dos 100 pacotes de 50 bytes cada foi de 142,9 ms. Já na distância de 700 metros ocorreu uma variação de $30 \%$, chegando a atingir $41 \%$ no setor de 1000 metros. Ao final das simulações constatouse que houve um aumento de $100,3 \%$ em relação ao tempo de envio do primeiro setor medido com relação ao último ponto de medição.

Com base nas recomendações sugeridas pelos órgãos regulamentadores apresentados no capítulo 4, o padrão ZigBee operou com tempo de atraso médio inferior a $450 \mathrm{~ms}$ nas distâncias simuladas, mantendo-se estável durante todo o experimento.

Em seguida, foram realizadas as simulações com o padrão IEEE 802.11ah, como pode ser observado na Figura 21. 
Figura 21 - Latência do padrão IEEE 802.11ah

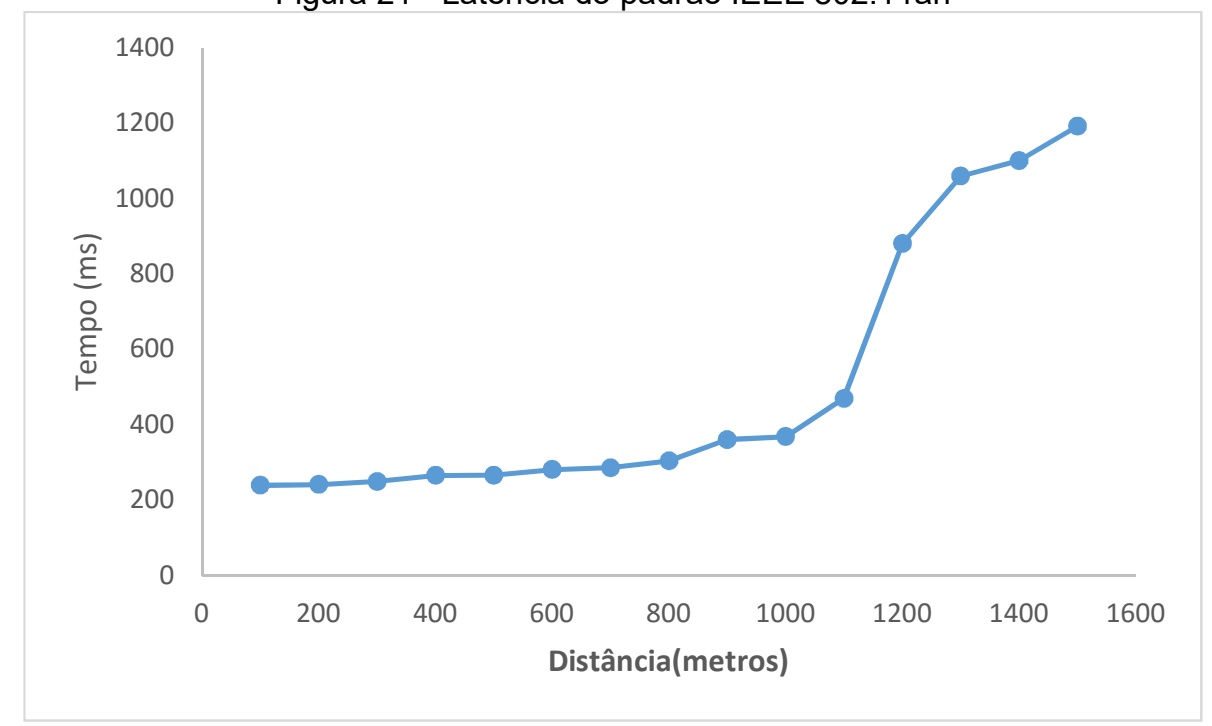

Fonte: Própria autoria.

O gráfico gerado a partir das simulações com o padrão IEEE 802.11ah permite visualizar a baixa variação do tempo da distância inicial - 100 metros até os 700 metros, ou seja, a variação do tempo foi de apenas $19 \%$. Contudo, a variação percentual do primeiro ponto de medição até o último ponto foi de aproximadamente $400 \%$, sendo que nas distâncias acima de 1300 metros ocorreram muitas falhas na transmissão devido à limitação da tecnologia 802.11ah.

O menor tempo obtido para esta tecnologia foi de $239 \mathrm{~ms}$ na distância de 100 metros e o maior valor foi de 1192 ms quando medido no ponto de 1500 metros. Porém, como os valores de Latência aceitáveis deveriam ser inferiores a $450 \mathrm{~ms}$, o padrão IEEE 802.11ah ultrapassou essa marca depois dos 1000 metros entre NR e NC.

\subsubsection{Latência - comparativo entre os padrões de transmissão}

Nas simulações envolvendo distância entre os pontos comunicadores e o tempo médio gasto para que a informação fosse processada pelo receptor pode-se observar uma pequena diferença entre os padrões ZigBee e IEEE 802.11ah nas medições iniciais, de acordo com a Tabela 8. 
Tabela 8 - Comparativo da Latência entre ZigBee e IEEE 802.11ah

\begin{tabular}{ccccc}
\hline Distância (metros) & Latência - ZigBee (ms) & $\begin{array}{c}\text { Variação } \\
\text { (\%) }\end{array}$ & $\begin{array}{c}\text { Latência 802.11ah } \\
\text { (ms) }\end{array}$ & $\begin{array}{c}\text { Variação } \\
(\%)\end{array}$ \\
\hline 100 & 142,9 & 0,0 & 239 & 0,0 \\
200 & 143,1 & 0,1 & 241,3 & 1,0 \\
300 & 165,3 & 15,5 & 248,8 & 3,1 \\
400 & 172,2 & 4,2 & 265,2 & 6,6 \\
500 & 174,2 & 1,2 & 265,7 & 0,2 \\
600 & 179,1 & 2,8 & 280,7 & 5,6 \\
700 & 185,9 & 3,8 & 285,6 & 1,7 \\
800 & 186,6 & 0,4 & 303,4 & 6,2 \\
900 & 196,2 & 5,1 & 360,3 & 18,8 \\
1000 & 201,8 & 2,9 & 368,3 & 2,2 \\
1100 & 211,2 & 4,7 & 469,8 & 27,6 \\
1200 & 214,3 & 1,5 & 880,4 & 87,4 \\
1300 & 231,6 & 8,1 & 1059,5 & 20,3 \\
1400 & 254,1 & 9,7 & 1100,8 & 3,9 \\
1500 & 286,3 & 12,7 & 1192 & 8,3 \\
\hline
\end{tabular}

Fonte: Própria autoria.

Verificou-se na Tabela 8 que, do início do experimento até a distância de 1000 metros houve uma variação média de $4 \%$ de aumento do tempo para o ZigBee e 5\% correspondente ao IEEE 802.11ah. Porém, nas distâncias superiores a 1000 metros, torna-se perceptível o aumento de variação do tempo em relação à segunda tecnologia.

Em relação à maior variação de tempo, conforme o aumento da distância observou-se que o protocolo IEEE 802.11ah apresentou uma variação de 87,4\%, em relação à distância anterior de 1100 metros.

A Figura 22 apresenta um gráfico comparativo de latência e, em paralelo com a Tabela 8, torna-se visível a diferença de tempo de entrega dos pacotes nas distância superiores a 1000 metros. 
Figura 22 - Gráfico de comparação entre os padrões ZigBee e 802.11ah

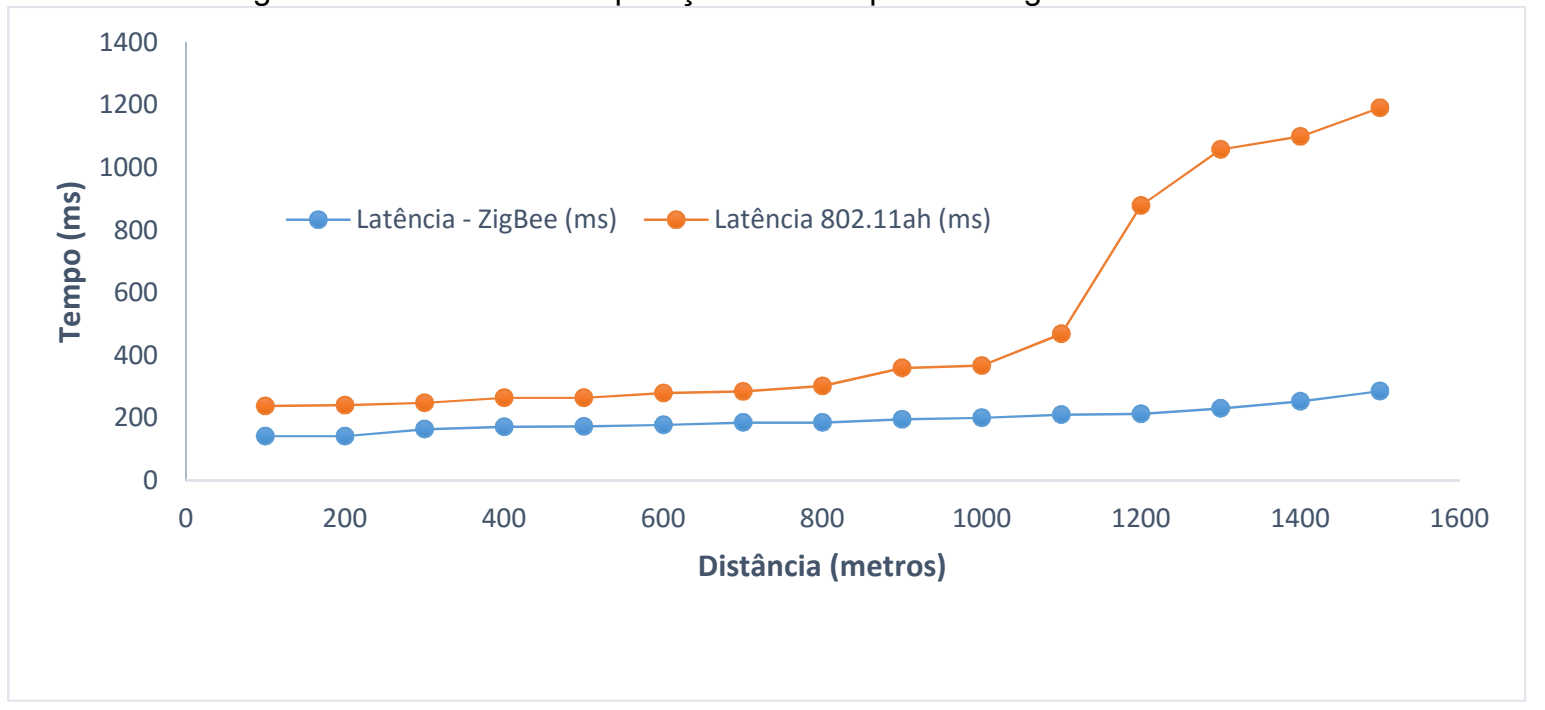

Fonte: Própria autoria.

Ao observar o gráfico na Figura 22 é possível diagnosticar que para uma área de cobertura de 1000 metros ambas as tecnologias apresentam a métrica latência com tempos próximos uma da outra. Todavia, o padrão ZigBee possui maior vantagem em sua utilização quando é necessário implementar uma RSSF para recobrimento de área com até 1500 metros, aproximadamente.

Por meio da regressão linear constatou-se que o valor-p apresentou nível de significância menor que 0,05 sendo confiável tanto para o padrão ZigBee quanto para o IEEE 802.11ah. Entretanto, analisando o tempo de demora na entrega de pacotes em uma distância de 1500 metros, a tecnologia ZigBee apresentou perda de 10,88 (ms) para cada metro percorrido e a tecnologia IEEE 802.11ah apresentou perda de 1,08 (ms).

Através da regressão observou-se uma interseção negativa $(-1325,82)$ em relação a tecnologia ZigBee, dessa forma, constatou-se que nas distâncias superiores a 1100 metros, houve menor tempo na entrega de pacotes com relação a tecnologia IEEE 802.11ah, na qual apresentou uma interseção positiva $(254,94)$ tendo como consequência um aumento no tempo na entrega de pacotes. A variação entre as duas tecnologias é mostrada na Figura 22, onde a tecnologia IEEE 802.11 ah começa a sofrer perda significativa de pacotes após 1100 metros de distância.

Já para o $\mathrm{R}^{2}$ ajustado, a tecnologia ZigBee apresentou um índice de qualidade de ajuste da regressão com o valor de $90,08 \%$ e o IEEE 802.11 ah de $72,17 \%$. 
Demais detalhes sobre os valores das regressões lineares realizadas se encontram nos APÊNDICES G e H.

\subsection{Dificuldades encontradas}

As simulações realizadas por meio do software OMNet++ foram executadas dentro de um ambiente controlado e configurado para esse fim. Todos os testes ocorreram conforme planejado devido às próprias características da ferramenta em oferecer recursos e condições necessárias para realizar os experimentos.

Entre os principais desafios encontrados pode-se destacar a necessidade de se criar um modelo que representasse o uso da tecnologia RSSF atuando em diversas aplicações do agronegócio. Devido às necessidades específicas de cada cliente, a implantação da tecnologia RSSF não dispõe de um modelo padrão disponível comercialmente, sendo necessário avaliar criteriosamente cada caso.

As simulações envolvendo fatores climáticos e meteorológicos também não fizeram parte dos testes devido às limitações do software, e por esse motivo não foram propostos esses eventos no objetivo deste trabalho. 


\section{Conclusão}

De acordo com os resultados obtidos por meio das simulações realizadas através do software OMNet++ 4.5, conclui-se que os objetivos propostos foram cumpridos dentro do planejado.

Através da investigação e dos testes realizados com os padrões de comunicação de ampla cobertura para redes de sensores sem fio, conclui-se que:

- As simulações executadas através do software OMNet++ demonstraram a eficácia dessa ferramenta para esse fim;

- As métricas: distância, taxa de perda de pacotes e latência foram suficientes para estabelecer quais dos padrões investigados ofereceu melhor desempenho, com relação à distância geográfica entre os pontos de comunicação de uma RSSF implantada em área rural;

- Os testes de distância relacionados com a TPP e a latência foram executados até os padrões de comunicação apresentarem valores insatisfatórios, os que permitiram analisar qual obteve melhor desempenho;

- Os padrões ZigBee e IEEE 802.11ah são tecnologias capazes de trabalhar em paralelo com os sensores sem fio e possibilitam a comunicação destes, em áreas rurais de grandes dimensões, porém ambos com suas respectivas limitações.

Com base nas simulações realizadas, verificou-se que o padrão ZigBee mostrou-se mais eficaz e estável que o padrão IEEE 802.11ah, com relação a distância física entre os dispositivos transmissores da RSSF.

Diante dos testes em que foi medido a quantidade de pacotes perdidos e o atraso médio, pode observar-se que conforme aumentava-se a distância entre o nó roteador e o nó coordenador no padrão ZigBee obteve-se melhor desempenho em ambas as métricas.

Ao analisar separadamente os valores das métricas TPP e latência verificou-se que o padrão ZigBee manteve-se mais estável em qualquer fase dos experimentos, já o IEEE 802.11ah apresentou instabilidade nas métricas: distância, TPP e latência; sendo que essa instabilidade foi ocasionada pelo aumento de distância dos nós de comunicação. 
Realizados todos os experimentos e discutido o comportamento de cada padrão com relação à capacidade de cobertura de sinal, pode-se afirmar que se o proprietário rural necessitar de uma tecnologia capaz de monitorar em tempo real sua lavoura ou seu rebanho, este tem à sua disposição as RSSF que são capazes de cobrirem áreas externas, com distâncias superiores a 1000 metros, ou seja, 314,15 hectares, aproximadamente.

Sugere-se como trabalho futuro, a realização de simulações computacionais aplicando aos cenários virtuais elementos climatológicos e geográficos com a finalidade de demonstrar o comportamento das tecnologias ZigBee e IEEE 802.11ah em uma RSSF diante de um ambiente mais próximo da realidade em campo. 


\section{Referências}

ADAME, T. et al. IEEE 802.11AH: the Wi-Fi approach for M2M communications. Wireless Communications (IEEE), v. 21, p. 144-152, dec. 2014.

ARCE, A. I. C. Redes de sensores sem fio na coleta de dados fisiológicos de bovinos para aplicações na zootecnia de precisão. 2008. 86p. Tese (Doutorado) - Faculdade de Zootecnia e Engenharia de Alimentos da Universidade de São Paulo, Pirassununga-SP, 2008.

AUST, S.; ITO, T. Sub 1GHz wireless LAN deployment scenarios and design implications in rural areas. In: GLOBECOM Workshops (GC Wkshps - IEEE), resume, 2011, Houston-USA. Houston-USA: IEEE, dec. 2011. p. 1045-1049.

BALDUINO, J. O.; ROCHA, M. N. Simulação de uma rede de sensor sem fio com base nos padrões zigbee e ieee 802.11ah. InterSciencePlace: Revista Científica Internacional. ed. 25, v. 1, art. P. 148, abr. jun. 2013.

BANKS, J.; NELSON, B. \& NICOL, D. Discrete-event system simulation. Prentice Hall, 2009.

CARVALHO, F. B. S. et al. Aplicações Ambientais de Redes de Sensores Sem Fio. Revista de Tecnologia da Informação e Comunicação, v. 2, n. 1, p. 14-19, Out. 2012.

CHIZZOTTI, M. L.; VALENTE, E. E. L. Zootecnia de precisão: uso de sensores na fazenda para maximizar a produtividade. In: XXIV Congresso Brasileiro de Zootecnia (ZOOTEC). 12-14 mai. 2014. Vitória-ES.

COAN, W. S. Simulação de sistemas distribuídos utilizando o OMNet++. 2013. In: 14ª Fórum Internacional do Software Livre (FISL). 03-06 jul. 2013, Centro de Eventos, PUC-RS, Porto Alegre-RS, 2013.

COSTA, F. G. Integração de veículos aéreos não tripulados e redes de sensores sem fio para aplicações agrícolas. 2013. 85 p. Dissertação (Mestrado) Intituto de Ciências e Matemáticas e Computação da Universidade de São Paulo, São Carlos-SP, 2013.

DANG, G.; CHENG, X. Application of wireless sensor network in monitoring system based on ZigBee. In: Advanced Research and Technology in Industry Applications (WARTIA), 2014 IEEE Workshop, Ottawa, ON. p. 181-183. 2014. 
DELISLE, J. J. The Difference Between IEEE 802.11af and 802.11ah. Disponível em: http://mwrf.com/active-components/what-s-difference-between-ieee-80211afand-80211ah>. Acesso em: 01. jun. 2015.

EVANGELISTA, P. et al. EbitSim: An Enchanced BitTorrent Simulation Using OMNet++ 4. Modeling, Analysis \& Simulation of Computer and Telecommunication Systems (MASCOTS), 2011 IEEE 19th International Symposium, pags. 437-440. Cingapura/Cingapura 25-27, Jul, 2011.

FOROUZAN, B. A. Comunicação de Dados e Redes de Computadores. 4 ed. São Paulo: McGraw-Hill, 2008.

FRIAS, R. N. ZigBee. Disponível em: < http://www.teleco.com.br/tutoriais/tutorialzigbee/default.asp>. Acesso em: 20. mai. 2015.

GARAY, J. R. B; KOFUJI, S. T. Uma Abordagem às Camadas Físicas e de Rede das Bandas ISM 915MHz e 2.4GHz: Um Estudo de Qualidade para sua aplicação Numa Rede de Sensores Sem Fio. 6th Ibero-American Congress on Sensors - Ibersensor 2008, 2008, São Paulo. Proceedings of Ibersensor 2008, 2008.

GITEL, P.; Sharma, M. Performance Evaluation of ad-hoc Network Routing Protocols using ns2 Simulation. International Journal of Network Security (ACEEE), v. 3, n. 1, p. 14-19, Jan. 2012.

GRANJAL, J.; MONTEIRO, E.; SILVA, J. S. Security in the integration of lowpower Wireless Sensor Networks with the Internet: A survey, Ad Hocs Networks, v. 24, part A, p. 264-284, Jan. 2015.

HEINZELMAN, W.; KULIK, J. Adaptive Protocols for Information Dissemination in Wireless Sensor Networks. ACM/IEEE MobiCom. 1999, pages: 174 - 185.

HENNING, M. Protocolo de roteamento para redes de sensores sem fio baseado em políticas. 2013. 95 p. Dissertação (Mestrado) - Pontifícia Universidade Católica do Paraná, Curitiba-PR, 2013.

Institute of Electrical and Electronics Engineers - IEEE. Official IEEE 802.11 working group project timelines - 2015-05-26: in process - Standards, Amendments, and Recommended Practices. Disponível em: < http://www.ieee802.org/11/Reports/802.11_Timelines.htm >. Acesso em: 02 jun. 2015. 
Institute of Electrical and Electronics Engineers - IEEE. IEEE Std 802.11 - specific requirements. IEEE Standard for Local and Metropolitan Area Networks:

Overview and Architecture. IEEE; 2014. (Revision to IEEE Std. 802 - 2001).

International Standardization Union - ITU-T. Recommendation G. 114. One Way Transmission Time. May 2003. Disponível em: <http://www.itu.int/rec/T-RECG.114-200305-I/en>. Acesso em: 14 jun. 2015.

JESUS, T. C.; SANTOS, N. H. Simulação de rede de sensores sem fio para veículos autônomos inteligentes utilizando OMNet++ e Mixim. In: XI Simpósio Brasileiro de Automação Inteligente (SBAI), Fortaleza-CE. 13-17 Out., 2013.

KAMARUDIN, L. M. et al. Modeling and simulation of near-earth wireless sensor networks for agriculture based application using OMNet++. In: Computer Applications and Industrial Electronics (ICCAIE), 2010, Kuala Lumpur. p. 131-136.

KAUR, L.; TALWAR, R. Review for Leach Protocol in WSN. International Journal of Advances in Science and Technology (IJAST), v. 2, issue 4, p. 31-33, 2014.

KHAN, M. Z. et al. Limitations of Simulation Tools for Large-Scale Wireless Sensor Networks. In: Advanced Information Networking and Applications (WAINA), 2011- IEEE Workshops of International Conference, 2011, Singapore: IEEE, 2011. p. $820-825$.

KODALI, R. K.; SARMA, N. Test bed for wireless sensor network using Xmesh networking protocol. In: Advances in Computing, Communications and Informatics (ICACCI), 2013 on International Conference. 22-25 Aug., 2013. p. 1506-1511.

KUROSE, J. F.; ROSS, K. W. Computer networking: a top-down approach featuring the Internet. 6 ed. São Paulo: Pearson, 2012.

LALA, B. et al. Carne bovina com qualidade. Brazilian Journal of Biosystems Engineering, v. 7, n. 2, p. 105-111, 2013.

LIN, J. et al. Novel Design and Analysis of Aggregated ARQ Protocols for IEEE 802.11n Networks. In: Mobile Computing, IEEE Transactions, v. 12, n. 3, p. 556570, 2012.

LOUREIRO, A. A. F. Redes de Sensores Sem Fio. In: Conferência: Grandes desafios da pesquisa em computação para o período 2006-2016. 08-09 mai. 2006. São Paulo-SP. 
MESSIAS, A. R. Controle remoto e aquisição de dados via XBee/ZigBee (IEEE 802.15.4). Disponível em: < http://www.rogercom.com/ZigBee/ZigBee.htm>. Acesso em: 14 ago. 2014.

NAAS, I. A. Incorporação de Novas Ferramentas para a Zootecnia de Precisão. Revista Brasileira de Zootecnia, v. 40, p. 358-364, 2011.

NADIMI, E. S. et al. Monitoring and classifying animal behavior using ZigBee-based mobile ad hoc wireless sensor networks and artificial neural networks. Computers and Eletronics in Agriculture, v. 82, p. 44-54, 2012.

OLIVEIRA, J. P. C. M. Modelagem, implementação e simulação de um protocolo de comunicação em tempo real para uma rede de sensores sem fio. Revista Innover, Fortaleza-CE, v. 1 n. 4.18 dez. 2014.

OTHMAN, M. F; SHAZALI, K. Wireless Sensor Network Applications: A Study in Environment Monitoring System. International Symposium on Robotics and Intelligent Sensors 2012 (IRIS 2012), p. 1204-1210, 2012.

QUTAIBA, L. A. Simulation Framework of Wireless Sensor Network (WSN) using MATLAB/SIMULINK Software. Disponível em: $<$ http://www.intechopen.com/books/matlab-a-fundamental-tool-for-scientíficcomputing-and-engineering-applications-volume-2/simulation-framework-of-wirelesssensor-network-wsn-using-matlab-simulink-software>. Acesso em: 15. mar. 2013.

RABER, A. et al. Aplicação de Redes de Sensores Sem Fio (RSSF) na Agricultura. In: Encontro Anual de Tecnologia da Informação e Semana Acadêmica de Tecnologia da Informação, ano 3, $n^{0} 1,2013$, Frederico Westphalen-RS. Anais do EATI. Frederico Westphalen. p. 261-265, nov. 2013.

RIBEIRO, C. H. P. Redes de Sensores sem Fio. Disponível em: $<$ http://www.gta.ufrj.br/grad/08_1/rssf/Padres.html\#Topic9>. Acesso em: 04. Jun. 2015.

RUIZ, L. B. MANNA: Uma Arquitetura para o Gerenciamento de Redes de Sensores Sem Fio. Tese (doutorado) - Universidade Federal de Minas Gerais, 2003.

SHUBEITA, F. M. et al. WSN Experiment and grid-based network architecture proposal. In: Computing System Engineering (SBESC), 2012 Brazilian Symposium. 5-7 nov. 2012, Natal. p. 225-228. 
SIGRIMIS, N. et al. Prospects in agricultural engineering in the information age. CIGRE Journal, invited paper, Hokkaido - Japan, v.1, n.1, p. 1-20, 1999.

SILVA, V. R. Uma Proposta para Automatização do Monitoramento da Interceptação Luminosa em Pastagens Utilizando uma Rede de Sensores sem Fio de Baixo Custo. 2014. 137 p. Dissertação (Mestrado) - Instituto de Informática da Universidade Federal de Goiás, Goiânia-GO, 2014.

SNAJDER, B.; JELICIC, V.; BILAS, V. Performance Evaluation of IEEE 802.15.4 and 802.11 Protocols for Image Transmission in WSNs. In: EUROPEAN WIRELESS 2014; 20TH EUROPEAN WIRELESS CONFERENCE, 2014, BarcelonaSpain. Proceedings... Barcelona-Spain: VDE, 2014. p. 1-6.

SOUZA, D. A. R. L. et al. Experimentos de alcance máximo de transmissão do ZigBee em ambiente urbano. In: Anais do Encontro Regional de Computação e Sistemas de Informação (ENCOSIS). 25-27 abr. 2013, Manaus-AM, 2013.

SPERQUE, A., H.; BRANQUINHO, O. C. Criação de Redes Ad Hoc para Redes de Sensores Sem Fio. In: Anais do XV Encontro de Iniciação Científica PUC Campinas. 26-27 out., Campinas-SP, 2010.

SUN, W.; CHOI, M. IEEE 802.11AH: A Long Range 802.11 WLAN at Sub 1GHz. Journal of ICT Standardization, v. 1, p 83-108, Seoul, 14 may. 2013.

SZILAGYI, R.; HERDON, M. Mobile Internet Applications, Infrastructure and Services. In: World Congress on Computers In Agriculture, 4, 2008, Orlando-USA. Proceedings... Orlando: American Society of Agricultural and Biological Engineers, 2008. p. 269-290.

TANENBAUM, A. S. Redes de Computadores. 5 ed. Rio de Janeiro: Elsevier, 2011.

TECH, A. R. B. Desenvolvimento de uma ferramenta computacional para monitoramento e coleta de dados, baseado em conceitos de e-Science e Data Warehouse para aplicação na Pecuária. 2008. 129p. Tese (Doutorado) Faculdade de Zootecnia e Engenharia de Alimentos da Universidade de São Paulo, Pirassununga-SP, 2008.

TEXAS INSTRUMENTS.CC1101 Low-power Sub-1 GHz RF Transceiver, 2011. Disponível em: http://www.ti.com/product/CC1101. Acesso em: 11 out. 2015. 
TILAK, S. et al. A taxonomy of wireless micro-sensor network models. In: Proceedings of the ACM Workshop on Wireless Security, ACM Press, 2002. p. 2836.

VERONA, A. B. Simulação e análise de redes sem fio aplicadas á viticultura. 2010. 119p. Pós-Graduação em Ciência da Computação da Universidade Estadual de Maringá-PR, 2010.

ZARPELON, M. C. et al. Tecnologias digitais: promovendo o desenvolvimento sustentável para o jovem do campo. Revista Eletrônica em Gestão, Educação e Tecnologia Ambiental - REGET. v. 19, n. 1, jan. - abr. 2015, p. 64-70. Disponível em: <http://cascavel.ufsm.br/revistas/ojs-2.2.2/index.php/reget/article/view/15435>. Acesso em: 25 ago. 2015.

ZIGBEE ALLIANCE. ZigBee 3.0: The Foundation for the Internet of Things. Disponível em: <http://www.zigbee.org/zigbee-for-developers/zigbee3-0/>. Acesso em: 20 mai. 2015.

YOUNIS, M. et al. Topology management techniques for tolerating node failures in wireless sensor networks: A survey. Computer Networks, v 58, p. 254-283, 2014. 


\section{Apêndice A - Análise da taxa de perda de pacotes: ZigBee}

\begin{tabular}{|c|c|c|c|c|c|}
\hline $\begin{array}{c}\text { Distancia } \\
\text { (mts) }\end{array}$ & Pacotes & Pacotes Recebidos & $\begin{array}{c}\% \\
\text { Sucesso }\end{array}$ & Pacotes Perdidos & $\begin{array}{c}\% \\
\text { Perdido }\end{array}$ \\
\hline 100 & 1000 & 998 & $99,80 \%$ & 2 & $0,20 \%$ \\
\hline 100 & 1000 & 999 & $99,90 \%$ & 1 & $0,10 \%$ \\
\hline 100 & 1000 & 999 & $99,90 \%$ & 1 & $0,10 \%$ \\
\hline 100 & 1000 & 998 & $99,80 \%$ & 2 & $0,20 \%$ \\
\hline 100 & 1000 & 997 & $99,70 \%$ & 3 & $0,30 \%$ \\
\hline 100 & 1000 & 999 & $99,90 \%$ & 1 & $0,10 \%$ \\
\hline 100 & 1000 & 1000 & $100,00 \%$ & 0 & $0,00 \%$ \\
\hline 100 & 1000 & 999 & $99,90 \%$ & 1 & $0,10 \%$ \\
\hline 100 & 1000 & 1000 & $100,00 \%$ & 0 & $0,00 \%$ \\
\hline \multirow[t]{2}{*}{100} & 1000 & 999 & $99,90 \%$ & 1 & $0,10 \%$ \\
\hline & Média & 998,8 & $99,88 \%$ & 1,2 & $0,12 \%$ \\
\hline $\begin{array}{c}\text { Distancia } \\
\text { (mts) }\end{array}$ & Pacotes & Pacotes Recebidos & $\begin{array}{c}\% \\
\text { Sucesso }\end{array}$ & Pacotes Perdidos & $\begin{array}{c}\% \\
\text { Perdido }\end{array}$ \\
\hline 200 & 1000 & 995 & $99,50 \%$ & 5 & $0,50 \%$ \\
\hline 200 & 1000 & 995 & $99,50 \%$ & 5 & $0,50 \%$ \\
\hline 200 & 1000 & 994 & $99,40 \%$ & 6 & $0,60 \%$ \\
\hline 200 & 1000 & 995 & $99,50 \%$ & 5 & $0,50 \%$ \\
\hline 200 & 1000 & 998 & $99,80 \%$ & 2 & $0,20 \%$ \\
\hline 200 & 1000 & 994 & $99,40 \%$ & 6 & $0,60 \%$ \\
\hline 200 & 1000 & 995 & $99,50 \%$ & 5 & $0,50 \%$ \\
\hline 200 & 1000 & 994 & $99,40 \%$ & 6 & $0,60 \%$ \\
\hline 200 & 1000 & 994 & $99,40 \%$ & 6 & $0,60 \%$ \\
\hline \multirow[t]{2}{*}{200} & 1000 & 995 & $99,50 \%$ & 5 & $0,50 \%$ \\
\hline & Média & 994,9 & $99,49 \%$ & 5,1 & $0,51 \%$ \\
\hline $\begin{array}{c}\text { Distancia } \\
\text { (mts) }\end{array}$ & Pacotes & Pacotes Recebidos & $\begin{array}{c}\% \\
\text { Sucesso }\end{array}$ & Pacotes Perdidos & $\begin{array}{c}\% \\
\text { Perdido }\end{array}$ \\
\hline 300 & 1000 & 991 & $99,10 \%$ & 9 & $0,90 \%$ \\
\hline 300 & 1000 & 991 & $99,10 \%$ & 9 & $0,90 \%$ \\
\hline 300 & 1000 & 991 & $99,10 \%$ & 9 & $0,90 \%$ \\
\hline 300 & 1000 & 992 & $99,20 \%$ & 8 & $0,80 \%$ \\
\hline 300 & 1000 & 989 & $98,90 \%$ & 11 & $1,10 \%$ \\
\hline 300 & 1000 & 988 & $98,80 \%$ & 12 & $1,20 \%$ \\
\hline 300 & 1000 & 989 & $98,90 \%$ & 11 & $1,10 \%$ \\
\hline 300 & 1000 & 990 & $99,00 \%$ & 10 & $1,00 \%$ \\
\hline 300 & 1000 & 991 & $99,10 \%$ & 9 & $0,90 \%$ \\
\hline \multirow[t]{2}{*}{300} & 1000 & 991 & $99,10 \%$ & 9 & $0,90 \%$ \\
\hline & Média & 990,3 & $99,03 \%$ & 9,7 & $0,97 \%$ \\
\hline $\begin{array}{l}\text { Distancia } \\
\text { (mts) }\end{array}$ & Pacotes & Pacotes Recebidos & $\begin{array}{c}\% \\
\text { Sucesso }\end{array}$ & Pacotes Perdidos & $\begin{array}{c}\% \\
\text { Perdido }\end{array}$ \\
\hline
\end{tabular}




\begin{tabular}{|c|c|c|c|c|c|}
\hline 400 & 1000 & 984 & $98,40 \%$ & 16 & $1,60 \%$ \\
\hline 400 & 1000 & 986 & $98,60 \%$ & 14 & $1,40 \%$ \\
\hline 400 & 1000 & 986 & $98,60 \%$ & 14 & $1,40 \%$ \\
\hline 400 & 1000 & 986 & $98,60 \%$ & 14 & $1,40 \%$ \\
\hline 400 & 1000 & 985 & $98,50 \%$ & 15 & $1,50 \%$ \\
\hline 400 & 1000 & 984 & $98,40 \%$ & 16 & $1,60 \%$ \\
\hline 400 & 1000 & 984 & $98,40 \%$ & 16 & $1,60 \%$ \\
\hline 400 & 1000 & 984 & $98,40 \%$ & 16 & $1,60 \%$ \\
\hline 400 & 1000 & 984 & $98,40 \%$ & 16 & $1,60 \%$ \\
\hline \multirow[t]{2}{*}{400} & 1000 & 984 & $98,40 \%$ & 16 & $1,60 \%$ \\
\hline & Média & 984,7 & $98,47 \%$ & 15,3 & $1,53 \%$ \\
\hline $\begin{array}{c}\text { Distancia } \\
\text { (mts) }\end{array}$ & Pacotes & Pacotes Recebidos & $\begin{array}{c}\% \\
\text { Sucesso }\end{array}$ & Pacotes Perdidos & $\begin{array}{c}\% \\
\text { Perdido }\end{array}$ \\
\hline 500 & 1000 & 969 & $96,90 \%$ & 31 & $3,10 \%$ \\
\hline 500 & 1000 & 969 & $96,90 \%$ & 31 & $3,10 \%$ \\
\hline 500 & 1000 & 968 & $96,80 \%$ & 32 & $3,20 \%$ \\
\hline 500 & 1000 & 970 & $97,00 \%$ & 30 & $3,00 \%$ \\
\hline 500 & 1000 & 970 & $97,00 \%$ & 30 & $3,00 \%$ \\
\hline 500 & 1000 & 969 & $96,90 \%$ & 31 & $3,10 \%$ \\
\hline 500 & 1000 & 969 & $96,90 \%$ & 31 & $3,10 \%$ \\
\hline 500 & 1000 & 970 & $97,00 \%$ & 30 & $3,00 \%$ \\
\hline 500 & 1000 & 968 & $96,80 \%$ & 32 & $3,20 \%$ \\
\hline \multirow[t]{2}{*}{500} & 1000 & 968 & $96,80 \%$ & 32 & $3,20 \%$ \\
\hline & Média & 969 & $96,90 \%$ & 31 & $3,10 \%$ \\
\hline $\begin{array}{l}\text { Distancia } \\
\text { (mts) }\end{array}$ & Pacotes & Pacotes Recebidos & $\begin{array}{c}\% \\
\text { Sucesso }\end{array}$ & Pacotes Perdidos & $\begin{array}{c}\% \\
\text { Perdido }\end{array}$ \\
\hline 600 & 1000 & 974 & $97,40 \%$ & 26 & $2,60 \%$ \\
\hline 600 & 1000 & 974 & $97,40 \%$ & 26 & $2,60 \%$ \\
\hline 600 & 1000 & 967 & $96,70 \%$ & 33 & $3,30 \%$ \\
\hline 600 & 1000 & 967 & $96,70 \%$ & 33 & $3,30 \%$ \\
\hline 600 & 1000 & 968 & $96,80 \%$ & 32 & $3,20 \%$ \\
\hline 600 & 1000 & 970 & $97,00 \%$ & 30 & $3,00 \%$ \\
\hline 600 & 1000 & 966 & $96,60 \%$ & 34 & $3,40 \%$ \\
\hline 600 & 1000 & 966 & $96,60 \%$ & 34 & $3,40 \%$ \\
\hline 600 & 1000 & 966 & $96,60 \%$ & 34 & $3,40 \%$ \\
\hline \multirow[t]{2}{*}{600} & 1000 & 966 & $96,60 \%$ & 34 & $3,40 \%$ \\
\hline & Média & 968,4 & $96,84 \%$ & 31,6 & $3,16 \%$ \\
\hline $\begin{array}{l}\text { Distancia } \\
\text { (mts) }\end{array}$ & Pacotes & Pacotes Recebidos & $\begin{array}{c}\% \\
\text { Sucesso }\end{array}$ & Pacotes Perdidos & $\begin{array}{c}\% \\
\text { Perdido }\end{array}$ \\
\hline 700 & 1000 & 968 & $96,80 \%$ & 32 & $3,20 \%$ \\
\hline 700 & 1000 & 964 & $96,40 \%$ & 36 & $3,60 \%$ \\
\hline 700 & 1000 & 964 & $96,40 \%$ & 36 & $3,60 \%$ \\
\hline 700 & 1000 & 964 & $96,40 \%$ & 36 & $3,60 \%$ \\
\hline
\end{tabular}




\begin{tabular}{|c|c|c|c|c|c|}
\hline 700 & 1000 & 966 & $96,60 \%$ & 34 & $3,40 \%$ \\
\hline 700 & 1000 & 960 & $96,00 \%$ & 40 & $4,00 \%$ \\
\hline 700 & 1000 & 960 & $96,00 \%$ & 40 & $4,00 \%$ \\
\hline 700 & 1000 & 966 & $96,60 \%$ & 34 & $3,40 \%$ \\
\hline 700 & 1000 & 964 & $96,40 \%$ & 36 & $3,60 \%$ \\
\hline \multirow[t]{2}{*}{700} & 1000 & 964 & $96,40 \%$ & 36 & $3,60 \%$ \\
\hline & Média & 964 & $96,40 \%$ & 36 & $3,60 \%$ \\
\hline Distancia & & & $\%$ & & $\%$ \\
\hline (mts) & Pacotes & Pacotes Recebidos & Sucesso & Pacotes Perdidos & Perdido \\
\hline 800 & 1000 & 942 & $94,20 \%$ & 58 & $5,80 \%$ \\
\hline 800 & 1000 & 942 & $94,20 \%$ & 58 & $5,80 \%$ \\
\hline 800 & 1000 & 942 & $94,20 \%$ & 58 & $5,80 \%$ \\
\hline 800 & 1000 & 943 & $94,30 \%$ & 57 & $5,70 \%$ \\
\hline 800 & 1000 & 946 & $94,60 \%$ & 54 & $5,40 \%$ \\
\hline 800 & 1000 & 944 & $94,40 \%$ & 56 & $5,60 \%$ \\
\hline 800 & 1000 & 944 & $94,40 \%$ & 56 & $5,60 \%$ \\
\hline 800 & 1000 & 944 & $94,40 \%$ & 56 & $5,60 \%$ \\
\hline 800 & 1000 & 943 & $94,30 \%$ & 57 & $5,70 \%$ \\
\hline \multirow[t]{2}{*}{800} & 1000 & 944 & $94,40 \%$ & 56 & $5,60 \%$ \\
\hline & Média & 943,4 & $94,34 \%$ & 56,6 & $5,66 \%$ \\
\hline \multicolumn{2}{|l|}{ Distancia } & & $\%$ & & $\%$ \\
\hline (mts) & Pacotes & Pacotes Recebidos & Sucesso & Pacotes Perdidos & Perdido \\
\hline 900 & 1000 & 922 & $92,20 \%$ & 78 & $7,80 \%$ \\
\hline 900 & 1000 & 929 & $92,90 \%$ & 71 & $7,10 \%$ \\
\hline 900 & 1000 & 935 & $93,50 \%$ & 65 & $6,50 \%$ \\
\hline 900 & 1000 & 935 & $93,50 \%$ & 65 & $6,50 \%$ \\
\hline 900 & 1000 & 922 & $92,20 \%$ & 78 & $7,80 \%$ \\
\hline 900 & 1000 & 922 & $92,20 \%$ & 78 & $7,80 \%$ \\
\hline 900 & 1000 & 931 & $93,10 \%$ & 69 & $6,90 \%$ \\
\hline 900 & 1000 & 931 & $93,10 \%$ & 69 & $6,90 \%$ \\
\hline 900 & 1000 & 931 & $93,10 \%$ & 69 & $6,90 \%$ \\
\hline \multirow[t]{2}{*}{900} & 1000 & 931 & $93,10 \%$ & 69 & $6,90 \%$ \\
\hline & Média & 928,9 & $92,89 \%$ & 71,1 & $7,11 \%$ \\
\hline \multicolumn{2}{|l|}{ Distancia } & & $\%$ & & $\%$ \\
\hline (mts) & Pacotes & Pacotes Recebidos & Sucesso & Pacotes Perdidos & Perdido \\
\hline 1000 & 1000 & 925 & $92,50 \%$ & 75 & $7,50 \%$ \\
\hline 1000 & 1000 & 925 & $92,50 \%$ & 75 & $7,50 \%$ \\
\hline 1000 & 1000 & 933 & $93,30 \%$ & 67 & $6,70 \%$ \\
\hline 1000 & 1000 & 933 & $93,30 \%$ & 67 & $6,70 \%$ \\
\hline 1000 & 1000 & 932 & $93,20 \%$ & 68 & $6,80 \%$ \\
\hline 1000 & 1000 & 932 & $93,20 \%$ & 68 & $6,80 \%$ \\
\hline 1000 & 1000 & 932 & $93,20 \%$ & 68 & $6,80 \%$ \\
\hline 1000 & 1000 & 919 & $91,90 \%$ & 81 & $8,10 \%$ \\
\hline
\end{tabular}




\begin{tabular}{|c|c|c|c|c|c|}
\hline 1000 & 1000 & 919 & $91,90 \%$ & 81 & $8,10 \%$ \\
\hline \multirow[t]{2}{*}{1000} & 1000 & 919 & $91,90 \%$ & 81 & $8,10 \%$ \\
\hline & Média & 926,9 & $92,69 \%$ & 73,1 & $7,31 \%$ \\
\hline \multicolumn{2}{|l|}{ Distancia } & Pacotes Recebidos & $\begin{array}{c}\% \\
\text { Sucesso }\end{array}$ & Pacotes Perdidos & $\begin{array}{c}\% \\
\text { Perdido }\end{array}$ \\
\hline 1100 & 1000 & 916 & $91,60 \%$ & 84 & $8,40 \%$ \\
\hline 1100 & 1000 & 910 & $91,00 \%$ & 90 & $9,00 \%$ \\
\hline 1100 & 1000 & 911 & $91,10 \%$ & 89 & $8,90 \%$ \\
\hline 1100 & 1000 & 911 & $91,10 \%$ & 89 & $8,90 \%$ \\
\hline 1100 & 1000 & 911 & $91,10 \%$ & 89 & $8,90 \%$ \\
\hline 1100 & 1000 & 915 & $91,50 \%$ & 85 & $8,50 \%$ \\
\hline 1100 & 1000 & 917 & $91,70 \%$ & 83 & $8,30 \%$ \\
\hline 1100 & 1000 & 917 & $91,70 \%$ & 83 & $8,30 \%$ \\
\hline 1100 & 1000 & 909 & $90,90 \%$ & 91 & $9,10 \%$ \\
\hline \multirow[t]{2}{*}{1100} & 1000 & 917 & $91,70 \%$ & 83 & $8,30 \%$ \\
\hline & Média & 913,4 & $91,34 \%$ & 86,6 & $8,66 \%$ \\
\hline \multicolumn{2}{|l|}{ Distancia } & Pacotes Recebidos & $\begin{array}{c}\% \\
\text { Sucesso } \\
\end{array}$ & Pacotes Perdidos & $\begin{array}{c}\% \\
\text { Perdido } \\
\end{array}$ \\
\hline 1200 & 1000 & 911 & $91,10 \%$ & 89 & $8,90 \%$ \\
\hline 1200 & 1000 & 911 & $91,10 \%$ & 89 & $8,90 \%$ \\
\hline 1200 & 1000 & 916 & $91,60 \%$ & 84 & $8,40 \%$ \\
\hline 1200 & 1000 & 917 & $91,70 \%$ & 83 & $8,30 \%$ \\
\hline 1200 & 1000 & 915 & $91,50 \%$ & 85 & $8,50 \%$ \\
\hline 1200 & 1000 & 914 & $91,40 \%$ & 86 & $8,60 \%$ \\
\hline 1200 & 1000 & 913 & $91,30 \%$ & 87 & $8,70 \%$ \\
\hline 1200 & 1000 & 906 & $90,60 \%$ & 94 & $9,40 \%$ \\
\hline 1200 & 1000 & 912 & $91,20 \%$ & 88 & $8,80 \%$ \\
\hline \multirow[t]{2}{*}{1200} & 1000 & 912 & $91,20 \%$ & 88 & $8,80 \%$ \\
\hline & Média & 912,7 & $91,27 \%$ & 87,3 & $8,73 \%$ \\
\hline \multicolumn{2}{|l|}{ Distancia } & Pacotes Recebidos & $\begin{array}{c}\% \\
\text { Sucesso } \\
\end{array}$ & Pacotes Perdidos & $\begin{array}{c}\% \\
\text { Perdido } \\
\end{array}$ \\
\hline 1300 & 1000 & 896 & $89,60 \%$ & 104 & $10,40 \%$ \\
\hline 1300 & 1000 & 901 & $90,10 \%$ & 99 & $9,90 \%$ \\
\hline 1300 & 1000 & 903 & $90,30 \%$ & 97 & $9,70 \%$ \\
\hline 1300 & 1000 & 896 & $89,60 \%$ & 104 & $10,40 \%$ \\
\hline 1300 & 1000 & 904 & $90,40 \%$ & 96 & $9,60 \%$ \\
\hline 1300 & 1000 & 898 & $89,80 \%$ & 102 & $10,20 \%$ \\
\hline 1300 & 1000 & 904 & $90,40 \%$ & 96 & $9,60 \%$ \\
\hline 1300 & 1000 & 904 & $90,40 \%$ & 96 & $9,60 \%$ \\
\hline 1300 & 1000 & 901 & $90,10 \%$ & 99 & $9,90 \%$ \\
\hline \multirow[t]{2}{*}{1300} & 1000 & 898 & $89,80 \%$ & 102 & $10,20 \%$ \\
\hline & Média & 900,5 & $90,05 \%$ & 99,5 & $9,95 \%$ \\
\hline
\end{tabular}




\begin{tabular}{|c|c|c|c|c|c|}
\hline $\begin{array}{c}\text { Distancia } \\
\text { (mts) }\end{array}$ & Pacotes & Pacotes Recebidos & $\begin{array}{c}\% \\
\text { Sucesso } \\
\end{array}$ & Pacotes Perdidos & $\begin{array}{c}\% \\
\text { Perdido } \\
\end{array}$ \\
\hline 1400 & 1000 & 874 & $87,40 \%$ & 126 & $12,60 \%$ \\
\hline 1400 & 1000 & 874 & $87,40 \%$ & 126 & $12,60 \%$ \\
\hline 1400 & 1000 & 873 & $87,30 \%$ & 127 & $12,70 \%$ \\
\hline 1400 & 1000 & 882 & $88,20 \%$ & 118 & $11,80 \%$ \\
\hline 1400 & 1000 & 883 & $88,30 \%$ & 117 & $11,70 \%$ \\
\hline 1400 & 1000 & 883 & $88,30 \%$ & 117 & $11,70 \%$ \\
\hline 1400 & 1000 & 881 & $88,10 \%$ & 119 & $11,90 \%$ \\
\hline 1400 & 1000 & 879 & $87,90 \%$ & 121 & $12,10 \%$ \\
\hline 1400 & 1000 & 881 & $88,10 \%$ & 119 & $11,90 \%$ \\
\hline \multirow[t]{2}{*}{1400} & 1000 & 881 & $88,10 \%$ & 119 & $11,90 \%$ \\
\hline & Média & 879,1 & $87,91 \%$ & 120,9 & $12,09 \%$ \\
\hline \multicolumn{2}{|l|}{ Distancia } & Pacotes Recebidos & $\begin{array}{c}\% \\
\text { Sucesso }\end{array}$ & Pacotes Perdidos & $\begin{array}{c}\% \\
\text { Perdido }\end{array}$ \\
\hline 1500 & 1000 & 851 & $85,10 \%$ & 149 & $14,90 \%$ \\
\hline 1500 & 1000 & 851 & $85,10 \%$ & 149 & $14,90 \%$ \\
\hline 1500 & 1000 & 854 & $85,40 \%$ & 146 & $14,60 \%$ \\
\hline 1500 & 1000 & 861 & $86,10 \%$ & 139 & $13,90 \%$ \\
\hline 1500 & 1000 & 859 & $85,90 \%$ & 141 & $14,10 \%$ \\
\hline 1500 & 1000 & 854 & $85,40 \%$ & 146 & $14,60 \%$ \\
\hline 1500 & 1000 & 855 & $85,50 \%$ & 145 & $14,50 \%$ \\
\hline 1500 & 1000 & 855 & $85,50 \%$ & 145 & $14,50 \%$ \\
\hline 1500 & 1000 & 861 & $86,10 \%$ & 139 & $13,90 \%$ \\
\hline \multirow[t]{2}{*}{1500} & 1000 & 861 & $86,10 \%$ & 139 & $13,90 \%$ \\
\hline & Média & 856,2 & $85,62 \%$ & 143,8 & $14,38 \%$ \\
\hline
\end{tabular}


Apêndice B - Análise da taxa de perda de pacotes: IEEE 802.11ah

\begin{tabular}{|c|c|c|c|c|c|}
\hline $\begin{array}{c}\text { Distância } \\
\text { (mts) }\end{array}$ & Pacotes & Pacotes Recebidos & $\begin{array}{c}\% \\
\text { Sucesso }\end{array}$ & Pacotes Perdidos & $\begin{array}{c}\% \\
\text { Perdido } \\
\end{array}$ \\
\hline 100 & 1000 & 999 & $99,90 \%$ & 1 & $0,10 \%$ \\
\hline 100 & 1000 & 999 & $99,90 \%$ & 1 & $0,10 \%$ \\
\hline 100 & 1000 & 999 & $99,90 \%$ & 1 & $0,10 \%$ \\
\hline 100 & 1000 & 999 & $99,90 \%$ & 1 & $0,10 \%$ \\
\hline 100 & 1000 & 997 & $99,70 \%$ & 3 & $0,30 \%$ \\
\hline 100 & 1000 & 997 & $99,70 \%$ & 3 & $0,30 \%$ \\
\hline 100 & 1000 & 998 & $99,80 \%$ & 2 & $0,20 \%$ \\
\hline 100 & 1000 & 999 & $99,90 \%$ & 1 & $0,10 \%$ \\
\hline 100 & 1000 & 998 & $99,80 \%$ & 2 & $0,20 \%$ \\
\hline \multirow[t]{2}{*}{100} & 1000 & 999 & $99,90 \%$ & 1 & $0,10 \%$ \\
\hline & Média & 998,4 & $99,84 \%$ & 1,6 & $0,16 \%$ \\
\hline Distância & Pacotes & Pacotes Recebidos & $\begin{array}{c}\% \\
\text { Sucesso }\end{array}$ & Pacotes Perdidos & $\begin{array}{c}\% \\
\text { Perdido }\end{array}$ \\
\hline 200 & 1000 & 999 & $99,90 \%$ & 1 & $0,10 \%$ \\
\hline 200 & 1000 & 998 & $99,80 \%$ & 2 & $0,20 \%$ \\
\hline 200 & 1000 & 999 & $99,90 \%$ & 1 & $0,10 \%$ \\
\hline 200 & 1000 & 998 & $99,80 \%$ & 2 & $0,20 \%$ \\
\hline 200 & 1000 & 998 & $99,80 \%$ & 2 & $0,20 \%$ \\
\hline 200 & 1000 & 997 & $99,70 \%$ & 3 & $0,30 \%$ \\
\hline 200 & 1000 & 998 & $99,80 \%$ & 2 & $0,20 \%$ \\
\hline 200 & 1000 & 998 & $99,80 \%$ & 2 & $0,20 \%$ \\
\hline 200 & 1000 & 998 & $99,80 \%$ & 2 & $0,20 \%$ \\
\hline \multirow[t]{2}{*}{200} & 1000 & 999 & $99,90 \%$ & 1 & $0,10 \%$ \\
\hline & Média & 998,2 & $99,82 \%$ & 1,8 & $0,18 \%$ \\
\hline \multicolumn{2}{|l|}{ Distância } & Pacotes Recebidos & $\begin{array}{c}\% \\
\text { Sucesso }\end{array}$ & Pacotes Perdidos & $\begin{array}{c}\% \\
\text { Perdido } \\
\end{array}$ \\
\hline 300 & 1000 & 994 & $99,40 \%$ & 6 & $0,60 \%$ \\
\hline 300 & 1000 & 995 & $99,50 \%$ & 5 & $0,50 \%$ \\
\hline 300 & 1000 & 995 & $99,50 \%$ & 5 & $0,50 \%$ \\
\hline 300 & 1000 & 995 & $99,50 \%$ & 5 & $0,50 \%$ \\
\hline 300 & 1000 & 994 & $99,40 \%$ & 6 & $0,60 \%$ \\
\hline 300 & 1000 & 995 & $99,50 \%$ & 5 & $0,50 \%$ \\
\hline 300 & 1000 & 993 & $99,30 \%$ & 7 & $0,70 \%$ \\
\hline 300 & 1000 & 994 & $99,40 \%$ & 6 & $0,60 \%$ \\
\hline 300 & 1000 & 995 & $99,50 \%$ & 5 & $0,50 \%$ \\
\hline \multirow[t]{2}{*}{300} & 1000 & 994 & $99,40 \%$ & 6 & $0,60 \%$ \\
\hline & Média & 994,4 & $99,44 \%$ & 5,6 & $0,56 \%$ \\
\hline $\begin{array}{l}\text { Distância } \\
\text { (mts) }\end{array}$ & Pacotes & Pacotes Recebidos & $\begin{array}{c}\% \\
\text { Sucesso }\end{array}$ & Pacotes Perdidos & $\begin{array}{c}\% \\
\text { Perdido }\end{array}$ \\
\hline
\end{tabular}




\begin{tabular}{|c|c|c|c|c|c|}
\hline 400 & 1000 & 991 & $99,10 \%$ & 9 & $0,90 \%$ \\
\hline 400 & 1000 & 991 & $99,10 \%$ & 9 & $0,90 \%$ \\
\hline 400 & 1000 & 987 & $98,70 \%$ & 13 & $1,30 \%$ \\
\hline 400 & 1000 & 990 & $99,00 \%$ & 10 & $1,00 \%$ \\
\hline 400 & 1000 & 990 & $99,00 \%$ & 10 & $1,00 \%$ \\
\hline 400 & 1000 & 987 & $98,70 \%$ & 13 & $1,30 \%$ \\
\hline 400 & 1000 & 991 & $99,10 \%$ & 9 & $0,90 \%$ \\
\hline 400 & 1000 & 991 & $99,10 \%$ & 9 & $0,90 \%$ \\
\hline 400 & 1000 & 990 & $99,00 \%$ & 10 & $1,00 \%$ \\
\hline \multirow[t]{2}{*}{400} & 1000 & 990 & $99,00 \%$ & 10 & $1,00 \%$ \\
\hline & Média & 989,8 & $98,98 \%$ & 10,2 & $1,02 \%$ \\
\hline \multicolumn{2}{|l|}{ Distância } & \multicolumn{3}{|c|}{$\%$} & $\%$ \\
\hline (mts) & Pacotes & Pacotes Recebidos & Sucesso & Pacotes Perdidos & Perdido \\
\hline 500 & 1000 & 984 & $98,40 \%$ & 16 & $1,60 \%$ \\
\hline 500 & 1000 & 984 & $98,40 \%$ & 16 & $1,60 \%$ \\
\hline 500 & 1000 & 985 & $98,50 \%$ & 15 & $1,50 \%$ \\
\hline 500 & 1000 & 988 & $98,80 \%$ & 12 & $1,20 \%$ \\
\hline 500 & 1000 & 984 & $98,40 \%$ & 16 & $1,60 \%$ \\
\hline 500 & 1000 & 984 & $98,40 \%$ & 16 & $1,60 \%$ \\
\hline 500 & 1000 & 983 & $98,30 \%$ & 17 & $1,70 \%$ \\
\hline 500 & 1000 & 984 & $98,40 \%$ & 16 & $1,60 \%$ \\
\hline 500 & 1000 & 986 & $98,60 \%$ & 14 & $1,40 \%$ \\
\hline \multirow[t]{2}{*}{500} & 1000 & 986 & $98,60 \%$ & 14 & $1,40 \%$ \\
\hline & Média & 984,8 & $98,48 \%$ & 15,2 & $1,52 \%$ \\
\hline \multicolumn{2}{|l|}{ Distância } & \multicolumn{3}{|c|}{$\%$} & $\%$ \\
\hline (mts) & Pacotes & Pacotes Recebidos & Sucesso & Pacotes Perdidos & Perdido \\
\hline 600 & 1000 & 977 & $97,70 \%$ & 23 & $2,30 \%$ \\
\hline 600 & 1000 & 977 & $97,70 \%$ & 23 & $2,30 \%$ \\
\hline 600 & 1000 & 977 & $97,70 \%$ & 23 & $2,30 \%$ \\
\hline 600 & 1000 & 975 & $97,50 \%$ & 25 & $2,50 \%$ \\
\hline 600 & 1000 & 975 & $97,50 \%$ & 25 & $2,50 \%$ \\
\hline 600 & 1000 & 976 & $97,60 \%$ & 24 & $2,40 \%$ \\
\hline 600 & 1000 & 975 & $97,50 \%$ & 25 & $2,50 \%$ \\
\hline 600 & 1000 & 977 & $97,70 \%$ & 23 & $2,30 \%$ \\
\hline 600 & 1000 & 977 & $97,70 \%$ & 23 & $2,30 \%$ \\
\hline \multirow[t]{2}{*}{600} & 1000 & 975 & $97,50 \%$ & 25 & $2,50 \%$ \\
\hline & Média & 976,1 & $97,61 \%$ & 23,9 & $2,39 \%$ \\
\hline \multicolumn{2}{|l|}{ Distância } & & $\%$ & & $\%$ \\
\hline (mts) & Pacotes & Pacotes Recebidos & Sucesso & Pacotes Perdidos & Perdido \\
\hline 700 & 1000 & 959 & $95,90 \%$ & 41 & $4,10 \%$ \\
\hline 700 & 1000 & 956 & $95,60 \%$ & 44 & $4,40 \%$ \\
\hline 700 & 1000 & 954 & $95,40 \%$ & 46 & $4,60 \%$ \\
\hline 700 & 1000 & 955 & $95,50 \%$ & 45 & $4,50 \%$ \\
\hline
\end{tabular}




\begin{tabular}{|c|c|c|c|c|c|}
\hline 700 & 1000 & 955 & $95,50 \%$ & 45 & $4,50 \%$ \\
\hline 700 & 1000 & 958 & $95,80 \%$ & 42 & $4,20 \%$ \\
\hline 700 & 1000 & 958 & $95,80 \%$ & 42 & $4,20 \%$ \\
\hline 700 & 1000 & 957 & $95,70 \%$ & 43 & $4,30 \%$ \\
\hline 700 & 1000 & 957 & $95,70 \%$ & 43 & $4,30 \%$ \\
\hline \multirow[t]{2}{*}{700} & 1000 & 958 & $95,80 \%$ & 42 & $4,20 \%$ \\
\hline & Média & 956,7 & $95,67 \%$ & 43,3 & $4,33 \%$ \\
\hline \multirow{2}{*}{$\begin{array}{c}\text { Distância } \\
\text { (mts) }\end{array}$} & & & $\%$ & & $\%$ \\
\hline & Pacotes & Pacotes Recebidos & Sucesso & Pacotes Perdidos & Perdido \\
\hline 800 & 1000 & 934 & $93,40 \%$ & 66 & $6,60 \%$ \\
\hline 800 & 1000 & 935 & $93,50 \%$ & 65 & $6,50 \%$ \\
\hline 800 & 1000 & 935 & $93,50 \%$ & 65 & $6,50 \%$ \\
\hline 800 & 1000 & 935 & $93,50 \%$ & 65 & $6,50 \%$ \\
\hline 800 & 1000 & 934 & $93,40 \%$ & 66 & $6,60 \%$ \\
\hline 800 & 1000 & 932 & $93,20 \%$ & 68 & $6,80 \%$ \\
\hline 800 & 1000 & 934 & $93,40 \%$ & 66 & $6,60 \%$ \\
\hline 800 & 1000 & 937 & $93,70 \%$ & 63 & $6,30 \%$ \\
\hline 800 & 1000 & 932 & $93,20 \%$ & 68 & $6,80 \%$ \\
\hline \multirow[t]{2}{*}{800} & 1000 & 932 & $93,20 \%$ & 68 & $6,80 \%$ \\
\hline & Média & 934 & $93,40 \%$ & 66 & $6,60 \%$ \\
\hline \multirow{2}{*}{$\begin{array}{c}\text { Distância } \\
\text { (mts) }\end{array}$} & & & $\%$ & & $\%$ \\
\hline & Pacotes & Pacotes Recebidos & Sucesso & Pacotes Perdidos & Perdido \\
\hline 900 & 1000 & 916 & $91,60 \%$ & 84 & $8,40 \%$ \\
\hline 900 & 1000 & 916 & $91,60 \%$ & 84 & $8,40 \%$ \\
\hline 900 & 1000 & 914 & $91,40 \%$ & 86 & $8,60 \%$ \\
\hline 900 & 1000 & 915 & $91,50 \%$ & 85 & $8,50 \%$ \\
\hline 900 & 1000 & 915 & $91,50 \%$ & 85 & $8,50 \%$ \\
\hline 900 & 1000 & 916 & $91,60 \%$ & 84 & $8,40 \%$ \\
\hline 900 & 1000 & 917 & $91,70 \%$ & 83 & $8,30 \%$ \\
\hline 900 & 1000 & 916 & $91,60 \%$ & 84 & $8,40 \%$ \\
\hline 900 & 1000 & 914 & $91,40 \%$ & 86 & $8,60 \%$ \\
\hline \multirow[t]{2}{*}{900} & 1000 & 915 & $91,50 \%$ & 85 & $8,50 \%$ \\
\hline & Média & 915,4 & $91,54 \%$ & 84,6 & $8,46 \%$ \\
\hline \multirow{2}{*}{$\begin{array}{l}\text { Distância } \\
\text { (mts) }\end{array}$} & & & $\%$ & & $\%$ \\
\hline & Pacotes & Pacotes Recebidos & Sucesso & Pacotes Perdidos & Perdido \\
\hline 1000 & 1000 & 898 & $89,80 \%$ & 102 & $10,20 \%$ \\
\hline 1000 & 1000 & 899 & $89,90 \%$ & 101 & $10,10 \%$ \\
\hline 1000 & 1000 & 899 & $89,90 \%$ & 101 & $10,10 \%$ \\
\hline 1000 & 1000 & 902 & $90,20 \%$ & 98 & $9,80 \%$ \\
\hline 1000 & 1000 & 905 & $90,50 \%$ & 95 & $9,50 \%$ \\
\hline 1000 & 1000 & 905 & $90,50 \%$ & 95 & $9,50 \%$ \\
\hline 1000 & 1000 & 901 & $90,10 \%$ & 99 & $9,90 \%$ \\
\hline 1000 & 1000 & 899 & $89,90 \%$ & 101 & $10,10 \%$ \\
\hline
\end{tabular}




\begin{tabular}{|c|c|c|c|c|c|}
\hline 1000 & 1000 & 899 & $89,90 \%$ & 101 & $10,10 \%$ \\
\hline \multirow[t]{2}{*}{1000} & 1000 & 899 & $89,90 \%$ & 101 & $10,10 \%$ \\
\hline & Média & 900,6 & $90,06 \%$ & 99,4 & $9,94 \%$ \\
\hline $\begin{array}{c}\text { Distância } \\
\text { (mts) }\end{array}$ & Pacotes & Pacotes Recebidos & $\begin{array}{c}\% \\
\text { Sucesso }\end{array}$ & Pacotes Perdidos & $\begin{array}{c}\% \\
\text { Perdido } \\
\end{array}$ \\
\hline 1100 & 1000 & 852 & $85,20 \%$ & 148 & $14,80 \%$ \\
\hline 1100 & 1000 & 852 & $85,20 \%$ & 148 & $14,80 \%$ \\
\hline 1100 & 1000 & 853 & $85,30 \%$ & 147 & $14,70 \%$ \\
\hline 1100 & 1000 & 854 & $85,40 \%$ & 146 & $14,60 \%$ \\
\hline 1100 & 1000 & 855 & $85,50 \%$ & 145 & $14,50 \%$ \\
\hline 1100 & 1000 & 855 & $85,50 \%$ & 145 & $14,50 \%$ \\
\hline 1100 & 1000 & 855 & $85,50 \%$ & 145 & $14,50 \%$ \\
\hline 1100 & 1000 & 859 & $85,90 \%$ & 141 & $14,10 \%$ \\
\hline 1100 & 1000 & 859 & $85,90 \%$ & 141 & $14,10 \%$ \\
\hline \multirow[t]{2}{*}{1100} & 1000 & 855 & $85,50 \%$ & 145 & $14,50 \%$ \\
\hline & Média & 854,9 & $85,49 \%$ & 145,1 & $14,51 \%$ \\
\hline \multicolumn{2}{|l|}{ Distância } & Pacotes Recebidos & $\begin{array}{c}\% \\
\text { Sucesso } \\
\end{array}$ & Pacotes Perdidos & $\begin{array}{c}\% \\
\text { Perdido } \\
\end{array}$ \\
\hline 1200 & 1000 & 823 & $82,30 \%$ & 177 & $17,70 \%$ \\
\hline 1200 & 1000 & 833 & $83,30 \%$ & 167 & $16,70 \%$ \\
\hline 1200 & 1000 & 834 & $83,40 \%$ & 166 & $16,60 \%$ \\
\hline 1200 & 1000 & 833 & $83,30 \%$ & 167 & $16,70 \%$ \\
\hline 1200 & 1000 & 838 & $83,80 \%$ & 162 & $16,20 \%$ \\
\hline 1200 & 1000 & 834 & $83,40 \%$ & 166 & $16,60 \%$ \\
\hline 1200 & 1000 & 836 & $83,60 \%$ & 164 & $16,40 \%$ \\
\hline 1200 & 1000 & 836 & $83,60 \%$ & 164 & $16,40 \%$ \\
\hline 1200 & 1000 & 836 & $83,60 \%$ & 164 & $16,40 \%$ \\
\hline \multirow[t]{2}{*}{1200} & 1000 & 835 & $83,50 \%$ & 165 & $16,50 \%$ \\
\hline & Média & 833,8 & $83,38 \%$ & 166,2 & $16,62 \%$ \\
\hline \multicolumn{2}{|l|}{ Distância } & Pacotes Recebidos & $\begin{array}{c}\% \\
\text { Sucesso } \\
\end{array}$ & Pacotes Perdidos & $\begin{array}{c}\% \\
\text { Perdido } \\
\end{array}$ \\
\hline 1300 & 1000 & 644 & $64,40 \%$ & 356 & $35,60 \%$ \\
\hline 1300 & 1000 & 644 & $64,40 \%$ & 356 & $35,60 \%$ \\
\hline 1300 & 1000 & 642 & $64,20 \%$ & 358 & $35,80 \%$ \\
\hline 1300 & 1000 & 642 & $64,20 \%$ & 358 & $35,80 \%$ \\
\hline 1300 & 1000 & 644 & $64,40 \%$ & 356 & $35,60 \%$ \\
\hline 1300 & 1000 & 648 & $64,80 \%$ & 352 & $35,20 \%$ \\
\hline 1300 & 1000 & 647 & $64,70 \%$ & 353 & $35,30 \%$ \\
\hline 1300 & 1000 & 647 & $64,70 \%$ & 353 & $35,30 \%$ \\
\hline 1300 & 1000 & 644 & $64,40 \%$ & 356 & $35,60 \%$ \\
\hline \multirow[t]{2}{*}{1300} & 1000 & 644 & $64,40 \%$ & 356 & $35,60 \%$ \\
\hline & Média & 644,6 & $64,46 \%$ & 355,4 & $35,54 \%$ \\
\hline
\end{tabular}




\begin{tabular}{|c|c|c|c|c|c|}
\hline $\begin{array}{c}\text { Distância } \\
\text { (mts) }\end{array}$ & Pacotes & Pacotes Recebidos & $\begin{array}{c}\% \\
\text { Sucesso }\end{array}$ & Pacotes Perdidos & $\begin{array}{c}\% \\
\text { Perdido }\end{array}$ \\
\hline 1400 & 1000 & 0 & $0,00 \%$ & 1000 & $100,00 \%$ \\
\hline 1400 & 1000 & 0 & $0,00 \%$ & 1000 & $100,00 \%$ \\
\hline 1400 & 1000 & 0 & $0,00 \%$ & 1000 & $100,00 \%$ \\
\hline 1400 & 1000 & 0 & $0,00 \%$ & 1000 & $100,00 \%$ \\
\hline 1400 & 1000 & 0 & $0,00 \%$ & 1000 & $100,00 \%$ \\
\hline 1400 & 1000 & 0 & $0,00 \%$ & 1000 & $100,00 \%$ \\
\hline 1400 & 1000 & 0 & $0,00 \%$ & 1000 & $100,00 \%$ \\
\hline 1400 & 1000 & 0 & $0,00 \%$ & 1000 & $100,00 \%$ \\
\hline 1400 & 1000 & 0 & $0,00 \%$ & 1000 & $100,00 \%$ \\
\hline \multirow[t]{2}{*}{1400} & 1000 & 0 & $0,00 \%$ & 1000 & $100,00 \%$ \\
\hline & Média & 0 & $0,00 \%$ & 1000 & $100,00 \%$ \\
\hline $\begin{array}{c}\text { Distância } \\
\text { (mts) }\end{array}$ & Pacotes & Pacotes Recebidos & $\begin{array}{c}\% \\
\text { Sucesso }\end{array}$ & Pacotes Perdidos & $\begin{array}{c}\% \\
\text { Perdido }\end{array}$ \\
\hline 1500 & 1000 & 0 & $0,00 \%$ & 1000 & $100,00 \%$ \\
\hline 1500 & 1000 & 0 & $0,00 \%$ & 1000 & $100,00 \%$ \\
\hline 1500 & 1000 & 0 & $0,00 \%$ & 1000 & $100,00 \%$ \\
\hline 1500 & 1000 & 0 & $0,00 \%$ & 1000 & $100,00 \%$ \\
\hline 1500 & 1000 & 0 & $0,00 \%$ & 1000 & $100,00 \%$ \\
\hline 1500 & 1000 & 0 & $0,00 \%$ & 1000 & $100,00 \%$ \\
\hline 1500 & 1000 & 0 & $0,00 \%$ & 1000 & $100,00 \%$ \\
\hline 1500 & 1000 & 0 & $0,00 \%$ & 1000 & $100,00 \%$ \\
\hline 1500 & 1000 & 0 & $0,00 \%$ & 1000 & $100,00 \%$ \\
\hline \multirow[t]{2}{*}{1500} & 1000 & 0 & $0,00 \%$ & 1000 & $100,00 \%$ \\
\hline & Média & 0 & $0,00 \%$ & 1000 & $100,00 \%$ \\
\hline
\end{tabular}




\section{Apêndice C - Regressão Linear da TPP para o padrão ZigBee}

\begin{tabular}{lr}
\hline \multicolumn{2}{c}{ Estatística de regressão } \\
\hline R múltiplo & 0,98357628 \\
R-Quadrado & 0,967422298 \\
R-Quadrado ajustado & $\mathbf{0 , 9 6 4 9 1 6 3 2 1}$ \\
Erro padrão & 0,008257324 \\
Observações & 15 \\
\hline
\end{tabular}

\begin{tabular}{lrrrrr}
\hline & Coeficientes & Erro padrão & Stat t & \multicolumn{1}{c}{ valor-P } \\
\hline & - & & & \\
Interseção & $\mathbf{0 , 0 1 9 6 9 2 3 8}$ & 0,004486684 & $-4,38907$ & 0,000732256 \\
Variável X1 & 0,00009696 & $4,93469 \mathrm{E}-06$ & 19,64805 & $\mathbf{0 , 0 0 0 0 0 0 0 0 0 0 5}$ \\
\hline
\end{tabular}

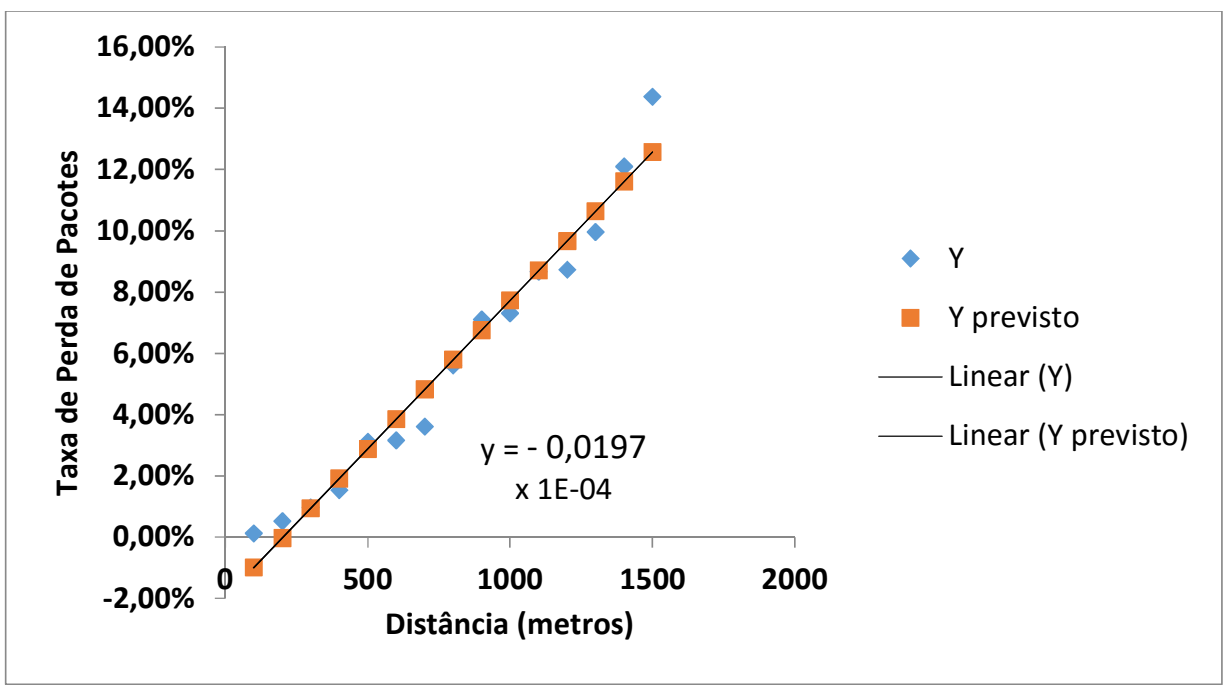




\section{Apêndice D - Regressão Linear da TPP para o padrão IEEE}

\subsection{1ah}

\begin{tabular}{lr}
\hline \multicolumn{2}{c}{ Estatística de regressão } \\
\hline R múltiplo & 0,754686824 \\
R-Quadrado & 0,569552203 \\
R-quadrado ajustado & $\mathbf{0 , 5 3 6 4 4 0 8 3 4}$ \\
Erro padrão & 0,229583325 \\
Observações & 15 \\
\hline
\end{tabular}

\begin{tabular}{lcccc}
\hline & Coeficientes & Erro padrão & Stat t & valor-P \\
\hline Interseção & $\mathbf{- 0 , 2 5 4 0 0 8 5 7 1}$ & 0,124745974 & $-2,03621$ & 0,062633873 \\
Variável X1 & 0,000569036 & 0,000137202 & 4,147422 & $\mathbf{0 , 0 0 1 1 4 6 7 3 5}$ \\
\hline
\end{tabular}

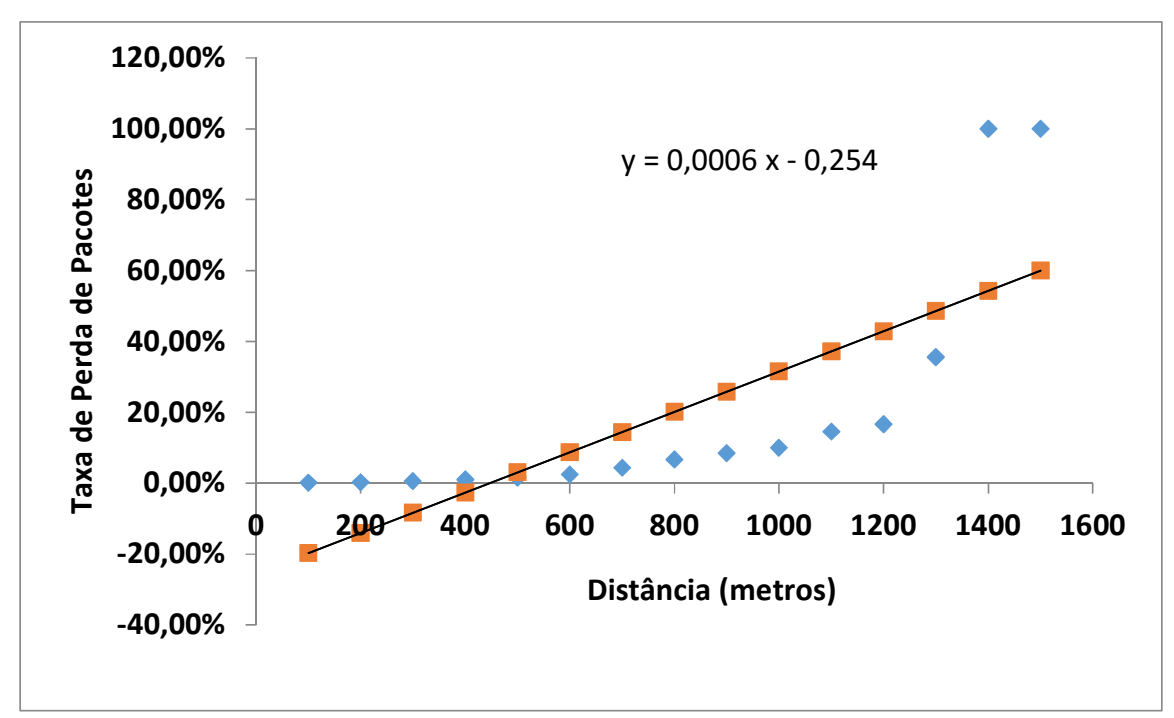




\section{Apêndice E - Análise da latência: ZigBee}

\begin{tabular}{ccc}
\hline & Distância (metros) & Latência (ms) \\
\hline 100 & 149 \\
100 & 125 \\
100 & 167 \\
100 & 134 \\
100 & 137 \\
100 & 142 \\
100 & 157 \\
100 & 142 \\
& 100 & 147 \\
Média & 100 & 129 \\
& & 142,9 \\
\hline
\end{tabular}

\begin{tabular}{|c|c|c|}
\hline & Distância (metros) & Latência (ms) \\
\hline & 200 & 144 \\
\hline & 200 & 126 \\
\hline & 200 & 132 \\
\hline & 200 & 141 \\
\hline & 200 & 161 \\
\hline & 200 & 159 \\
\hline & 200 & 151 \\
\hline & 200 & 147 \\
\hline & 200 & 134 \\
\hline & 200 & 137 \\
\hline \multirow[t]{12}{*}{ Média } & & 143,2 \\
\hline & Distância (metros) & Latência (ms) \\
\hline & 300 & 163 \\
\hline & 300 & 174 \\
\hline & 300 & 166 \\
\hline & 300 & 154 \\
\hline & 300 & 163 \\
\hline & 300 & 152 \\
\hline & 300 & 176 \\
\hline & 300 & 174 \\
\hline & 300 & 168 \\
\hline & 300 & 163 \\
\hline \multirow[t]{5}{*}{ Média } & & 165,3 \\
\hline & Distância (metros) & Latência (ms) \\
\hline & 400 & 178 \\
\hline & 400 & 163 \\
\hline & 400 & 181 \\
\hline
\end{tabular}




\begin{tabular}{ccc}
400 & 154 \\
400 & 168 \\
400 & 177 \\
400 & 166 \\
400 & 169 \\
& 400 & 175 \\
& 400 & 171 \\
Média & & 170,2 \\
\hline
\end{tabular}

\begin{tabular}{|c|c|c|}
\hline & Distância (metros) & Latência (ms) \\
\hline & 500 & 186 \\
\hline & 500 & 173 \\
\hline & 500 & 191 \\
\hline & 500 & 166 \\
\hline & 500 & 186 \\
\hline & 500 & 174 \\
\hline & 500 & 179 \\
\hline & 500 & 164 \\
\hline & 500 & 169 \\
\hline & 500 & 154 \\
\hline \multirow[t]{12}{*}{ Média } & & 174,2 \\
\hline & Distância (metros) & Latência (ms) \\
\hline & 600 & 194 \\
\hline & 600 & 179 \\
\hline & 600 & 182 \\
\hline & 600 & 191 \\
\hline & 600 & 177 \\
\hline & 600 & 172 \\
\hline & 600 & 185 \\
\hline & 600 & 171 \\
\hline & 600 & 168 \\
\hline & 600 & 172 \\
\hline \multirow[t]{12}{*}{ Média } & & 179,1 \\
\hline & Distância (metros) & Latência (ms) \\
\hline & 700 & 196 \\
\hline & 700 & 184 \\
\hline & 700 & 192 \\
\hline & 700 & 174 \\
\hline & 700 & 182 \\
\hline & 700 & 179 \\
\hline & 700 & 196 \\
\hline & 700 & 188 \\
\hline & 700 & 173 \\
\hline & 700 & 195 \\
\hline
\end{tabular}




\begin{tabular}{ccc} 
Média & \multicolumn{2}{c}{185,9} \\
\hline & & \\
\hline & Distância (metros) & Latência (ms) \\
\hline 800 & 194 \\
800 & 184 \\
800 & 186 \\
800 & 171 \\
800 & 194 \\
800 & 183 \\
800 & 187 \\
& 800 & 194 \\
& 800 & 181 \\
Média & 800 & 192 \\
& & 186,6 \\
\hline
\end{tabular}

\begin{tabular}{ccc}
\hline & Distância (metros) & Latência (ms) \\
\hline 900 & 202 \\
900 & 207 \\
900 & 193 \\
900 & 199 \\
900 & 193 \\
900 & 203 \\
900 & 197 \\
900 & 185 \\
& 900 & 190 \\
Média & 900 & 193 \\
& & 196,2 \\
\hline
\end{tabular}

\begin{tabular}{ccc}
\hline Distância (metros) & Latência (ms) \\
\hline 1000 & 199 \\
1000 & 214 \\
1000 & 205 \\
1000 & 209 \\
1000 & 200 \\
1000 & 193 \\
1000 & 183 \\
& 1000 & 204 \\
Média & 1000 & 210 \\
& 1000 & 201 \\
& & 201,8 \\
\hline
\end{tabular}

Distância (metros) Latência (ms)

$\begin{array}{ll}1100 & 223 \\ 1100 & 213 \\ 1100 & 198 \\ 1100 & 207\end{array}$




\begin{tabular}{|c|c|c|}
\hline & 1100 & 216 \\
\hline & 1100 & 208 \\
\hline & 1100 & 203 \\
\hline & 1100 & 219 \\
\hline & 1100 & 212 \\
\hline & 1100 & 213 \\
\hline \multirow[t]{12}{*}{ Média } & & 211,2 \\
\hline & Distância (metros) & Latência (ms) \\
\hline & 1200 & 237 \\
\hline & 1200 & 217 \\
\hline & 1200 & 229 \\
\hline & 1200 & 204 \\
\hline & 1200 & 238 \\
\hline & 1200 & 232 \\
\hline & 1200 & 242 \\
\hline & 1200 & 247 \\
\hline & 1200 & 231 \\
\hline & 1200 & 239 \\
\hline \multirow[t]{12}{*}{ Média } & & 231,6 \\
\hline & Distância (metros) & Latência (ms) \\
\hline & 1300 & 253 \\
\hline & 1300 & 241 \\
\hline & 1300 & 261 \\
\hline & 1300 & 228 \\
\hline & 1300 & 247 \\
\hline & 1300 & 260 \\
\hline & 1300 & 241 \\
\hline & 1300 & 251 \\
\hline & 1300 & 259 \\
\hline & 1300 & 233 \\
\hline \multirow[t]{12}{*}{ Média } & & 247,4 \\
\hline & Distância (metros) & Latência (ms) \\
\hline & 1400 & 269 \\
\hline & 1400 & 258 \\
\hline & 1400 & 253 \\
\hline & 1400 & 239 \\
\hline & 1400 & 241 \\
\hline & 1400 & 244 \\
\hline & 1400 & 251 \\
\hline & 1400 & 259 \\
\hline & 1400 & 266 \\
\hline & 1400 & 261 \\
\hline Média & & 254,1 \\
\hline
\end{tabular}




\begin{tabular}{ccc}
\hline Distância (metros) & Latência (ms) \\
\hline 1500 & 294 \\
1500 & 284 \\
1500 & 293 \\
1500 & 274 \\
1500 & 268 \\
1500 & 302 \\
1500 & 288 \\
& 1500 & 279 \\
Média & 1500 & 291 \\
& 1500 & 285 \\
& & 285,8 \\
\hline
\end{tabular}


Apêndice F - Análise da latência: IEEE 802.11ah

\begin{tabular}{ccc}
\hline Distância (metros) & Latência (ms) \\
\hline 100 & 249 \\
100 & 243 \\
100 & 236 \\
100 & 253 \\
100 & 231 \\
100 & 229 \\
100 & 247 \\
100 & 239 \\
100 & 239 \\
& 100 & 224 \\
& & 239 \\
\hline
\end{tabular}

\begin{tabular}{ccc}
\hline Distância (metros) & Latência (ms) \\
\hline 200 & 253 \\
200 & 241 \\
200 & 249 \\
200 & 256 \\
200 & 234 \\
200 & 242 \\
200 & 239 \\
200 & 234 \\
200 & 229 \\
200 & 236 \\
Média & & 241,3 \\
\hline
\end{tabular}

\begin{tabular}{ccc}
\hline Distância (metros) & Latência (ms) \\
\hline 300 & 258 \\
300 & 248 \\
300 & 256 \\
300 & 242 \\
300 & 261 \\
300 & 253 \\
300 & 249 \\
& 300 & 239 \\
& 300 & 244 \\
& 300 & 238 \\
Média & & 248,8 \\
\hline
\end{tabular}

\begin{tabular}{cc}
\hline Distância (metros) & Latência (ms) \\
\hline 400 & 271 \\
400 & 257 \\
400 & 266
\end{tabular}




\begin{tabular}{|c|c|c|}
\hline & 400 & 261 \\
\hline & 400 & 273 \\
\hline & 400 & 253 \\
\hline & 400 & 276 \\
\hline & 400 & 263 \\
\hline & 400 & 261 \\
\hline & 400 & 271 \\
\hline \multirow[t]{12}{*}{ Média } & & 265,2 \\
\hline & Distância (metros) & Latência (ms) \\
\hline & 500 & 264 \\
\hline & 500 & 273 \\
\hline & 500 & 269 \\
\hline & 500 & 261 \\
\hline & 500 & 266 \\
\hline & 500 & 253 \\
\hline & 500 & 264 \\
\hline & 500 & 281 \\
\hline & 500 & 256 \\
\hline & 500 & 270 \\
\hline \multirow[t]{12}{*}{ Média } & & 265,7 \\
\hline & Distância (metros) & Latência (ms) \\
\hline & 600 & 284 \\
\hline & 600 & 273 \\
\hline & 600 & 286 \\
\hline & 600 & 268 \\
\hline & 600 & 283 \\
\hline & 600 & 273 \\
\hline & 600 & 289 \\
\hline & 600 & 280 \\
\hline & 600 & 294 \\
\hline & 600 & 277 \\
\hline \multirow[t]{12}{*}{ Média } & & 280,7 \\
\hline & Distância (metros) & Latência (ms) \\
\hline & 700 & 292 \\
\hline & 700 & 274 \\
\hline & 700 & 273 \\
\hline & 700 & 284 \\
\hline & 700 & 279 \\
\hline & 700 & 296 \\
\hline & 700 & 286 \\
\hline & 700 & 287 \\
\hline & 700 & 291 \\
\hline & 700 & 294 \\
\hline
\end{tabular}




\begin{tabular}{ccc} 
Média & \multicolumn{2}{c}{285,6} \\
\hline & & \\
\hline & Distância (metros) & Latência (ms) \\
\hline 800 & 299 \\
800 & 305 \\
800 & 306 \\
800 & 301 \\
800 & 294 \\
800 & 302 \\
800 & 294 \\
& 800 & 311 \\
& 800 & 308 \\
& 800 & 314 \\
& & 303,4 \\
\hline
\end{tabular}

\begin{tabular}{ccc}
\hline & Distância (metros) & Latência (ms) \\
\hline 900 & 354 \\
900 & 341 \\
900 & 369 \\
900 & 364 \\
900 & 353 \\
900 & 374 \\
900 & 348 \\
900 & 352 \\
Média & 900 & 387 \\
& 900 & 361 \\
& & 360,3 \\
\hline
\end{tabular}

\begin{tabular}{ccc}
\hline & & \\
\hline Distância (metros) & Latência (ms) \\
\hline 1000 & 394 \\
1000 & 353 \\
1000 & 341 \\
1000 & 369 \\
1000 & 345 \\
1000 & 341 \\
1000 & 387 \\
1000 & 366 \\
1000 & 389 \\
& 1000 & 398 \\
Média & & 368,3 \\
\hline
\end{tabular}

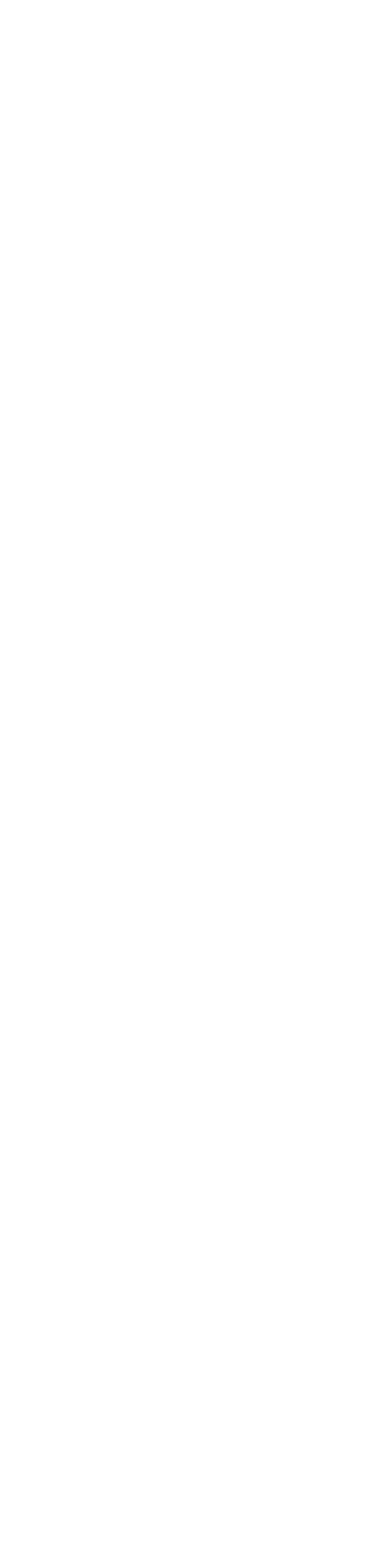

Distância (metros) Latência (ms)

$\begin{array}{ll}1100 & 486 \\ 1100 & 436 \\ 1100 & 444 \\ 1100 & 469\end{array}$




\begin{tabular}{ccc}
1100 & 457 \\
1100 & 451 \\
1100 & 503 \\
1100 & 487 \\
1100 & 473 \\
Média & 1100 & 492 \\
& & 469,8 \\
\hline & Distância (metros) & Latência (ms) \\
\hline & 1200 & 842 \\
1200 & 820 \\
1200 & 741 \\
& 1200 & 960 \\
& 1200 & 779 \\
& 1200 & 732 \\
& 1200 & 963 \\
& 1200 & 1006 \\
& 1200 & 936 \\
& 1200 & 1025 \\
& & 880,4 \\
\hline
\end{tabular}

\begin{tabular}{ccc}
\hline & Distância (metros) & Latência (ms) \\
\hline 1300 & 1050 \\
1300 & 1061 \\
1300 & 1096 \\
1300 & 1003 \\
1300 & 1011 \\
1300 & 1043 \\
1300 & 1132 \\
1300 & 1065 \\
1300 & 1085 \\
1300 & 1049 \\
Média & 1059,5 \\
\hline & \\
\hline Distância (metros) & Latência (ms) \\
\hline 1400 & 1101 \\
1400 & 1054 \\
1400 & 1123 \\
& 1400 & 1147 \\
1400 & 1095 \\
1400 & 1085 \\
& 1400 & 1192 \\
1400 & 1064 \\
1400 & 1032 \\
1400 & 1115 \\
& &
\end{tabular}




\begin{tabular}{ccc}
\hline Distância (metros) & Latência (ms) \\
\hline 1500 & 1163 \\
1500 & 1201 \\
1500 & 1178 \\
1500 & 1187 \\
1500 & 1196 \\
1500 & 1176 \\
1500 & 1203 \\
1500 & 1198 \\
& 1500 & 1204 \\
Média & 1500 & 1214 \\
& & 1192 \\
\hline
\end{tabular}




\section{Apêndice G - Regressão Linear da latência para o padrão ZigBee}

\begin{tabular}{lr}
\hline \multicolumn{2}{c}{ Estatística de regressão } \\
\hline R múltiplo & 0,952842241 \\
R-Quadrado & 0,907908335 \\
R-quadrado ajustado & $\mathbf{0 , 9 0 0 8 2 4 3 6 1}$ \\
Erro padrão & 140,8372386 \\
Observações & 15 \\
\hline
\end{tabular}

\begin{tabular}{lcccc}
\hline & \multicolumn{4}{c}{ Erro } \\
& Coeficientes & padrão & Stat $t$ & valor-P \\
\hline Interseção & $\mathbf{- 1 3 3 5 , 8 2 3 9 8 7}$ & 192,1339 & $-6,95257$ & $\mathbf{0 , 0 0 0 0 1 0 0 2 8 1 4}$ \\
Variável X1 & $\mathbf{1 0 , 8 7 9 6 6 8 4 9}$ & 0,961022 & 11,32094 & $\mathbf{0 , 0 0 0 0 0 0 0 4 1 8 9}$ \\
\hline
\end{tabular}

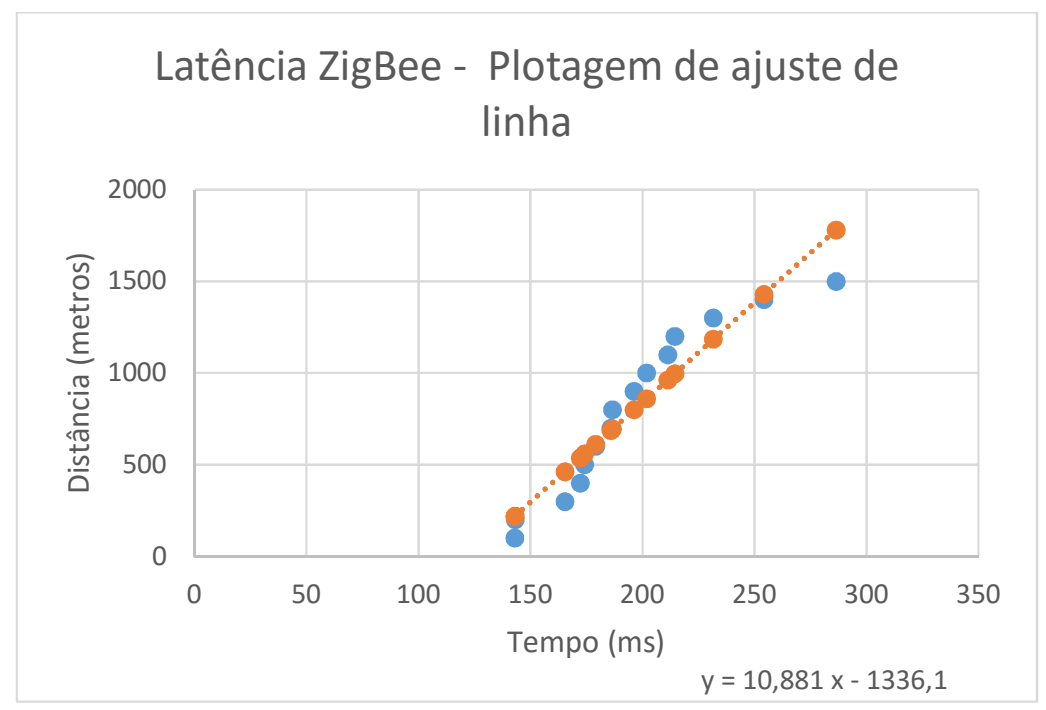




\section{Apêndice H - Regressão Linear da latência para o padrão IEEE}

\subsection{1ah}

\begin{tabular}{lr}
\hline \multicolumn{2}{c}{ Estatística de regressão } \\
\hline R múltiplo & 0,861201195 \\
R-Quadrado & 0,741667498 \\
R-quadrado ajustado & $\mathbf{0 , 7 2 1 7 9 5 7 6 7}$ \\
Erro padrão & 235,8831206 \\
Observações & 15 \\
\hline
\end{tabular}

\begin{tabular}{lcccc}
\hline & Coeficientes & Erro padrão & Stat t & valor-P \\
\hline Interseção & $\mathbf{2 5 4 , 9 4 4 4 5 1 1}$ & 108,0245182 & 2,360061 & $\mathbf{0 , 0 3 4 5 7 1 3 4 3}$ \\
Variável X 1 & $\mathbf{1 , 0 8 1 3 4 4 9 9 4}$ & 0,177001725 & 6,109234 & $\mathbf{0 , 0 0 0 0 3 7 2 4 5}$ \\
\hline
\end{tabular}

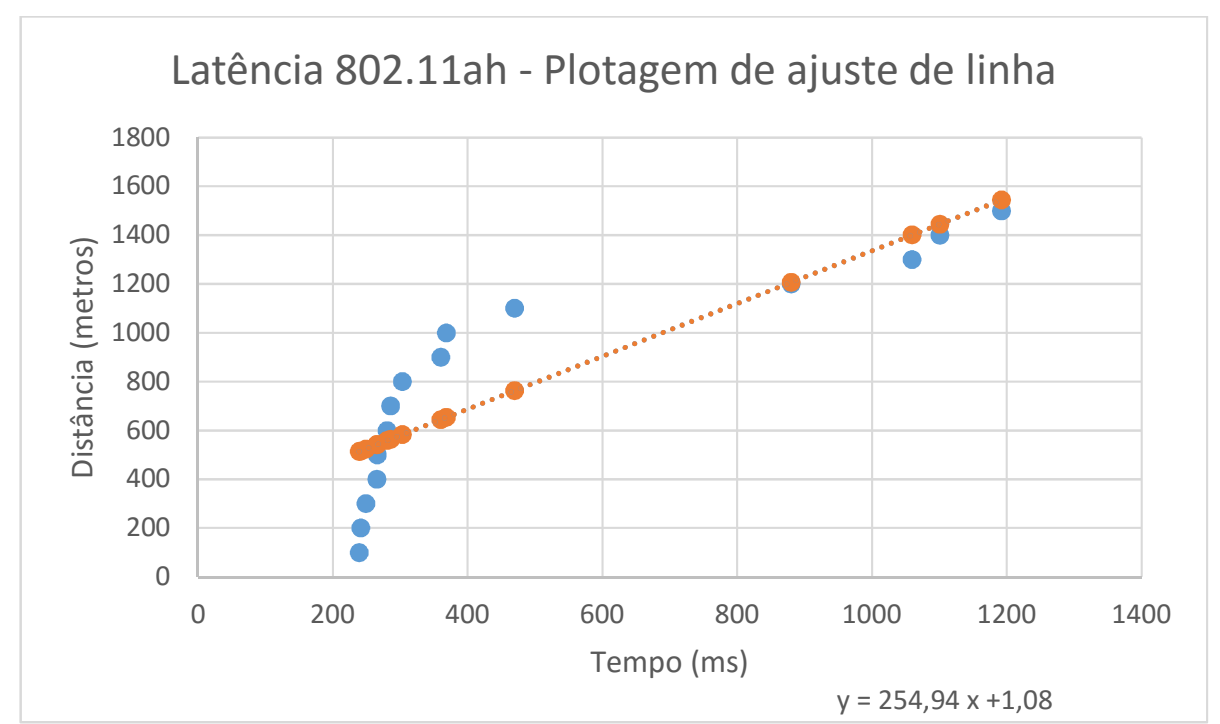

